\title{
Screening Report on Cell Materials for High-Power Li-Ion HEV Batteries
}

J. Liu, A. Kahaian, I. Belharouak, S. Kang, S. Oliver, G. Henriksen, and K. Amine

Argonne National Laboratory, Argonne, Illinois 60439 Operated by The University of Chicago For the United States Department of Energy under Contract W-31-109-Eng-38

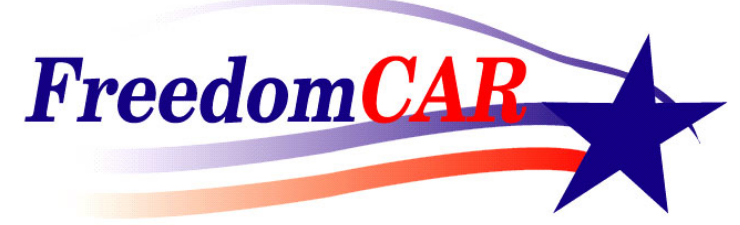

FreedomCAR \& Vehicle Technologies Office 
Argonne National Laboratory, with facilities in the states of Illinois and Idaho, is owned by the United States Government and operated by The University of Chicago under the provisions of a contract with the Department of Energy.

\begin{tabular}{l} 
DISCLAIMER \\
This report was prepared as an account of work sponsored by an agency of \\
the United States Government. Neither the United States Government nor \\
any agency thereof, nor The University of Chicago, nor any of their \\
employees or officers, makes any warranty, express or implied, or assumes \\
any legal liability or responsibility for the accuracy, completeness, or \\
usefulness of any information, apparatus, product, or process disclosed, or \\
represents that its use would not infringe privately owned rights. Reference \\
herein to any specific commercial product, process, or service by trade name, \\
trademark, manufacturer, or otherwise, does not necessarily constitute or \\
imply its endorsement, recommendation, or favoring by the United States \\
Government or any agency thereof. The views and opinions of document \\
authors expressed herein do not necessarily state or reflect those of the \\
United States Government or any agency thereof, Argonne National \\
Laboratory, or The University of Chicago. \\
\hline
\end{tabular}

Available electronically at http://www.doe.gov/bridge

Available for a processing fee to U.S. Department of Energy and its contractors, in paper, from:

U.S. Department of Energy

Office of Scientific and Technical Information

P.O. Box 62

Oak Ridge, TN 37831-0062

phone: (865) 576-8401

fax: (865) 576-5728

email: reports@adonis.osti.gov 


\begin{abstract}
ANL-03/16
ARGONNE NATIONAL LABORATORY

9700 S. Cass Ave.

Argonne, IL 60439

\section{Screening Report on Cell Materials for High-Power Li-Ion HEV Batteries}

\author{
by
}

J. Liu, A. Kahaian, I. Belharouak, S. Kang, S. Oliver, J. Kim, G. Henriksen, and K. Amine

Electrochemical Technology Program

Chemical Engineering Division

April 2003 


\section{GLOSSARY OF TERMS}

ASI

Gen $1(+)$

Gen $1(-)$

Gen 1 Electrolyte

Gen $2(+)$

Gen $2(-)$

Gen 2 Electrolyte HPPC test

LiBOB

LP40 electrolyte

MCMB

$\mathrm{PC}$

PVDF binder

SBR
Area specific impedance $\left(\mathrm{ohm}-\mathrm{cm}^{2}\right)$

$\mathrm{LiNi}_{0.8} \mathrm{Co}_{0.2} \mathrm{O}_{2}$ cathode

MCMB:SFG-6 (82:18)

LP40

$\mathrm{LiNi}_{0.8} \mathrm{Co}_{0.15} \mathrm{Al}_{0.05} \mathrm{O}_{2}$ cathode

MAG-10 synthetic graphite anode

1.2 $\mathrm{M} \mathrm{LiPF}_{6}$ EC:EMC (3:7)

Hybrid pulse power characterization test

Lithium bis(oxalato)borate

1.0 M LiPF 6 EC:DEC (50:50)

Mesocarbon microbeads

Propylene carbonate

Polyvinyledene fluoride

Soft butyl rubber 


\section{CONTENTS}

GLOSSARY OF TERMS.

EXECUTIVE SUMMARY

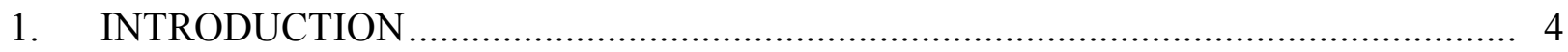

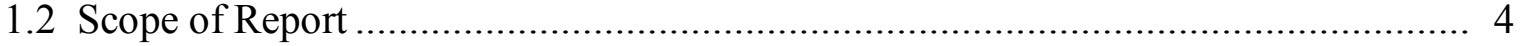

1.2 Techniques and Methods........................................................................ 5

2. COMPONENT TESTING PROTOCOLS ......................................................... 8

2.1 Rapid Screening Techniques ..................................................................... 8

3. ADVANCED CARBON ANODES .................................................................. 10

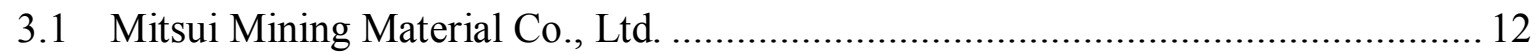

3.2 Daibeck Advanced Materials Co., Ltd........................................................ 15

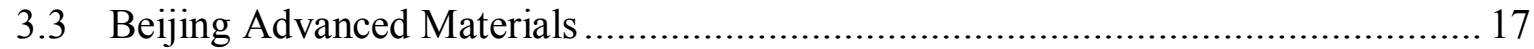

3.4 Superior Graphite...................................................................................... 19

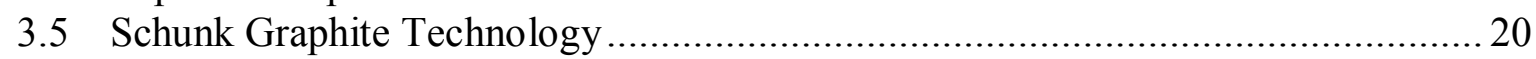

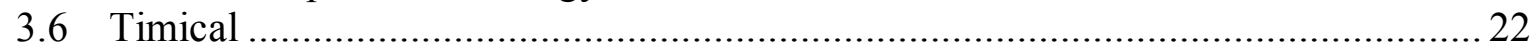

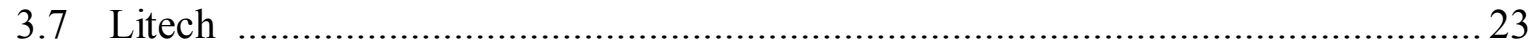

4. ADVANCED CATHODE MATERIALS ............................................................. 26

4.1 Advanced Layered Cathode Materials ....................................................... 27

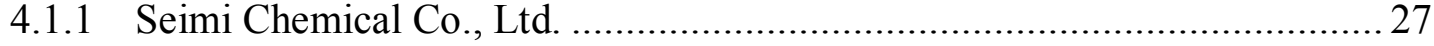

4.1.2 Fuji Chemical............................................................................... 31

4.2 Advanced $\mathrm{LiMn}_{2} \mathrm{O}_{4}$ Spinel Cathode Materials................................................. 32

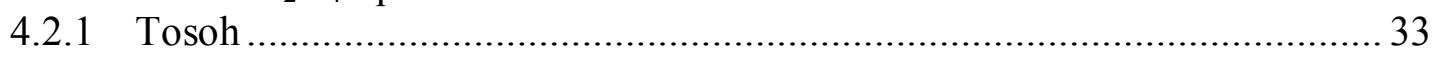

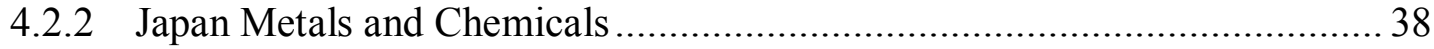

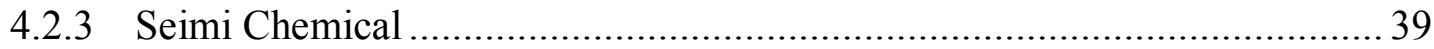

4.3 Other Advanced Cathode Materials ................................................................. 40

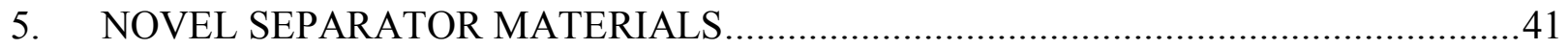

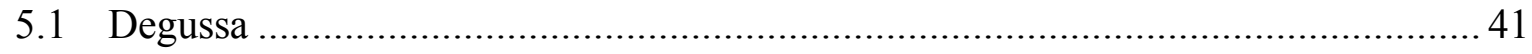

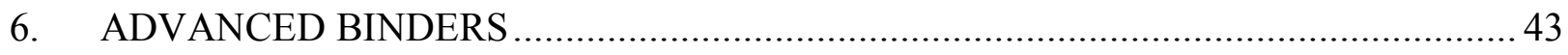

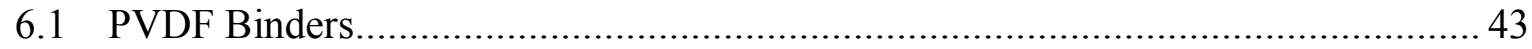

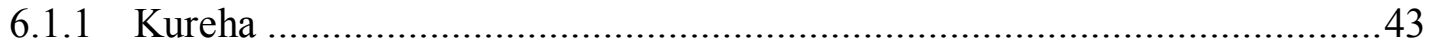

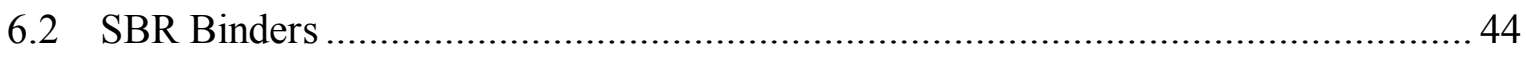

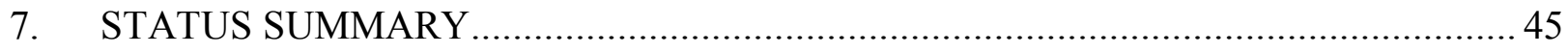

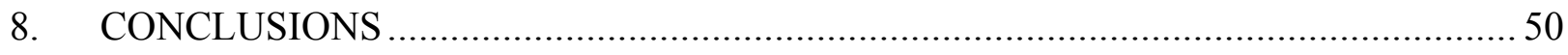

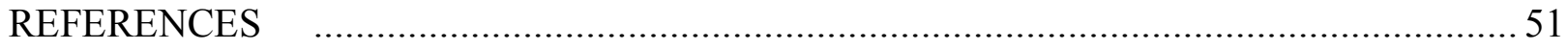


APPENDIX A. INDEX OF MATERIALS .

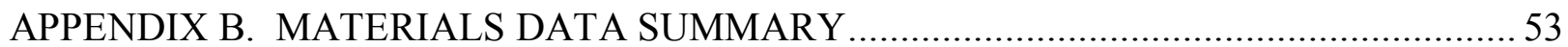

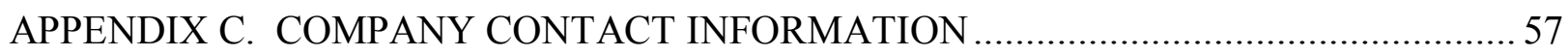




\section{TABLES}

\begin{tabular}{|c|c|}
\hline & $\underline{\text { Page }}$ \\
\hline ES-1. & Recommended Materials for Low-Cost, High-Power Cell Chemistries …...................... \\
\hline 1. & Materials Employed in Gen 2 Cells.... \\
\hline 2. & 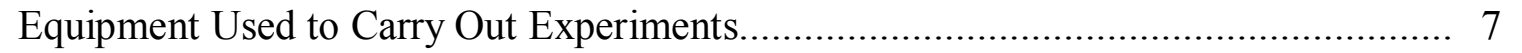 \\
\hline 3. & High-Volume Cost Projections for Gen 2 Anode Materials and Graphite Materials...... 11 \\
\hline 4. & High-Volume Cost Projections for Selected Advanced Cathode Materials ................... 26 \\
\hline 5. & Electrode Materials Selected for Two of the Most Promising Advanced \\
\hline & 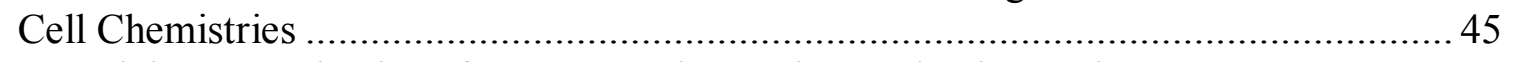 \\
\hline 6. & Material Cost Projections for Gen 2, Advanced A, and Advanced B \\
\hline
\end{tabular}

\section{FIGURES}

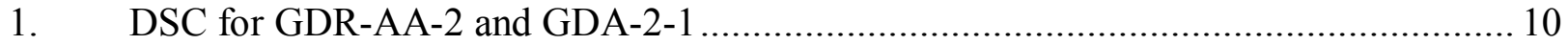

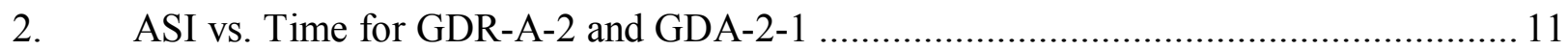

3. HR-TEM of Mitsui Mining GDA-N2-3 Cross Section ............................................... 13

4. SEM of Mitsui Mining Initial GDR-AA-3 and Improvements Obtained by

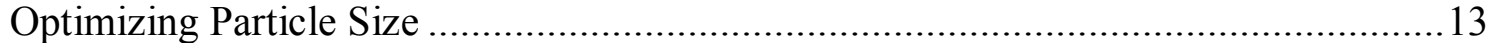

5. Initial Capacity Stability Data for Mitsui Mining GDR-AA-3 …................................14

6. 10C Rate HPPC Test Data for Mitsui Mining GDR-AA-3 …...................................14

7. Power Capability for Mitsui Mining GDR-AA-3 Calculated from HPPC Data...............14

8. $\quad$ ASI Values for Mitsui Mining GDR-AA-3 During Aggressive Aging ............................14

9. HPPC Test Data for Daibeck Advanced Materials DJG Graphite .................................16

10. Initial Capacity Stability Data for Daibeck Advanced Materials DJG Graphite .............16

11. Power Capability for Daibeck Advanced Materials DJG New 3 Graphite

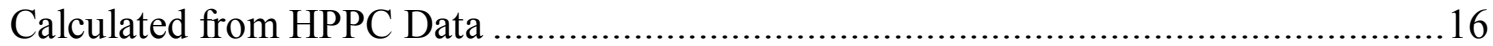

12. ASI vs. Time for Daibeck Advanced Materials DJG New 3 ……................................. 17

13. DSC Data for Daibeck Advanced Materials DJG New 3 ..............................................17

14. SEM Image of Beijing Advanced Materials SLC 10U...............................................18

15. HPPC Test Data for Beijing Advanced Materials SLC 10U .......................................18

16. Power Capability for Beijing Advanced Materials SLC 10U Calculated from

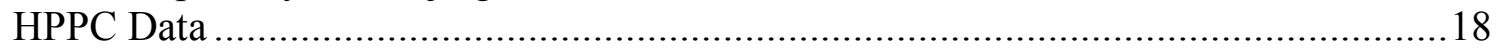

17. Variation of ASI vs. Time for Beijing Advanced Materials SLC 10U ………..............19

18. DSC for Beijing Advanced Materials SCL 10U ..................................................... 19

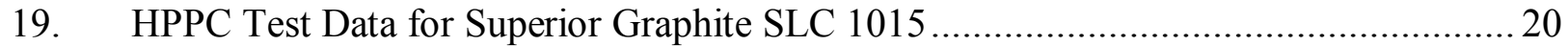

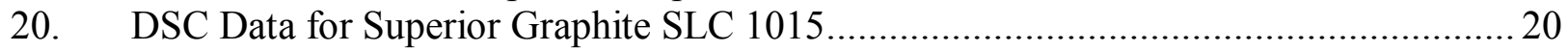

21. HPPC Test Data for Schunk Graphite Technology FU 2651 ....................................... 21

22. Power Capability for Schunk Graphite Technology FU 2651 Calculated from

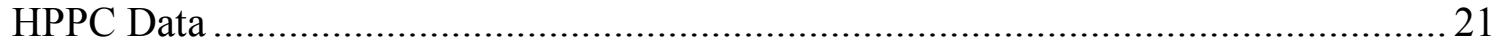

23. DSC Data for Schunk Graphite Technology FU 2651 Graphite in PC-Based

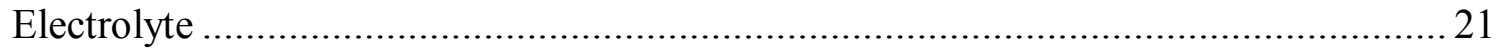

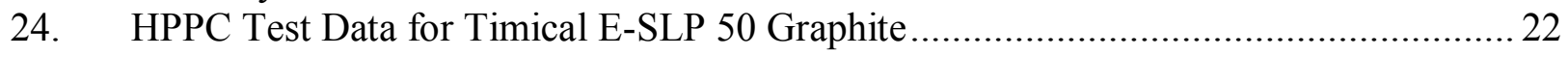


25. Power Capability for Timical E-SLP 50 Graphite Calculated from HPPC Data...........22

26. SEM Images of Surface and Cross Section of LiTech C-C Composite .......................23

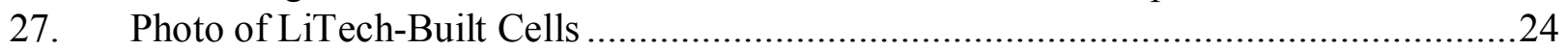

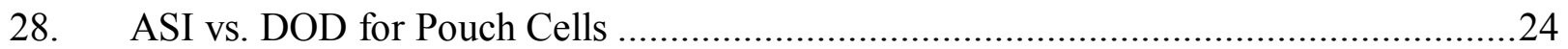

29. Power Capability for Pouch Cells Calculated from HPPC Test Data ..........................24

30. ASI vs. DOD for Lab Cell Employing ANL Gen 2 Cathode, Composite Carbon Fiber Anode, and 1.2 $\mathrm{M} \mathrm{LiPF}_{6}$ in EC/PC/DMC $(1: 1: 3)$ Electrolyte.............................25

31. Power Capability for Lab Cell Employing ANL Gen 2 Cathode, Composite Carbon Fiber Anode, and 1.2 $\mathrm{M} \mathrm{LiPF}_{6}$ in EC/PC/DMC (1:1:3) Electrolyte...........................25

32. Capacity Fade of Pouch Cells When Cycled between 1.0 and $4.2 \mathrm{~V}$ and 2.5 and $4.2 \mathrm{~V}$

33. Capacity Stability of Seimi Chemical L-333 Cathode Material in Cells with 1.2 M LiPF 6 (EC:PC:DMC) (1:1:3) Electrolyte and 1.2 M LiPF 6 (EC:PC:EMC)

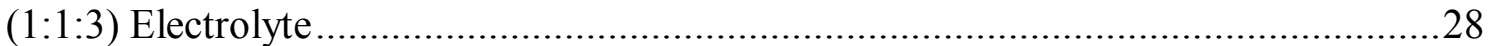

34. 10C Rate HPPC Test Data for Seimi Chemical L-333 Cathode .................................28

35. Power Capability for Seimi Chemical L-333 Cathode Calculated from HPPC Data .....28

36. Unit Cell Volume vs. SOC in Seimi Chemical Material ...........................................29

37. XRD Patterns for New and Cycled Seimi Chemical $\mathrm{LiNi}_{1 / 3} \mathrm{Co}_{1 / 3} \mathrm{Mn}_{1 / 3} \mathrm{O}_{2} \ldots \ldots \ldots \ldots \ldots \ldots . . . \ldots \ldots$

38. Comparative DSC of Seimi Chemical L-333 Cathode at Three States of Charge and Gen 1, Gen 2, and L-333 Cathodes ............................................................. 30

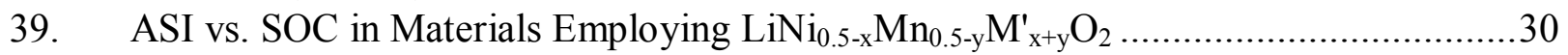

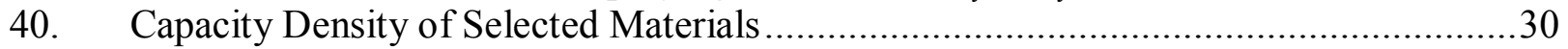

41. Capacity Retention of Fuji Chemical $\mathrm{LiNi}_{0.95} \mathrm{Ti}_{0.05} \mathrm{O}_{2}$ Cathode and $\mathrm{LiNi}_{0.92} \mathrm{Ti}_{0.05} \mathrm{Al}_{0.03} \mathrm{O}_{2}$ Cathode .................................................................... 31

42. HPPC Data for Fuji Chemical $\mathrm{LiNi}_{0.95} \mathrm{Ti}_{0.05} \mathrm{O}_{2}$ Cathode and

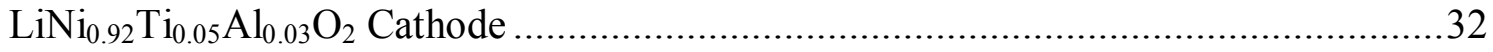

43. Capacity Stability of Tosho $\mathrm{Li}_{1.06} \mathrm{Mn}_{1.94} \mathrm{O}_{4}$ Material in Cell with Metallic Lithium Anode ............................................................................................... 34

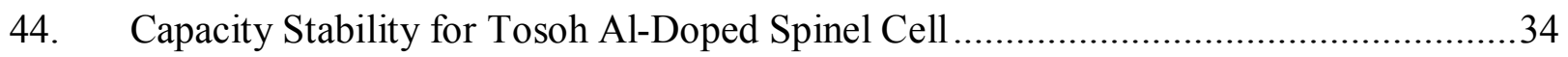

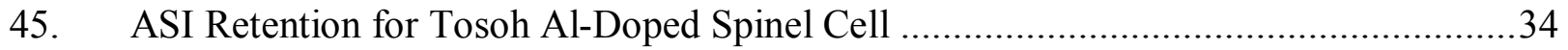

46. $\quad \mathrm{DSC}$ for $\mathrm{LiNi}_{0.8} \mathrm{Co}_{0.2} \mathrm{O}_{2}$ in $\mathrm{LiPF}_{6} \mathrm{EC}: \mathrm{DEC}$ (1:1) Electrolyte and Tosoh Spinel in LiBOB EC:DEC $(1: 1)$ Electrolyte ......................................... 35

47. Mn Concentration in LP40 Electrolyte Resulting from Three-Week Leach at $50^{\circ} \mathrm{C} \ldots \ldots 35$

48. Chemical Structure of LiBOB Salt ....................................................... 36

49. $\mathrm{Mn}^{2+}$ Dissolution in Electrolyte Using $\mathrm{LiPF}_{6}$ Electrolyte and LiBOB Electrolyte ......... 36

50. DSC for Spinel with LiBOB Electrolyte and $\mathrm{LiPF}_{6}$ Electrolyte ............................. 37

51. HPPC Test with Conventional Solvents (with LiBOB) and Chemetall M8 ................. 37

52. Capacity Fade in Cells Employing Tosoh Al-Doped Spinel with LiBOB

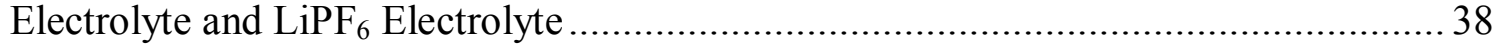

53. Capacity Fade in Japan Metals and Chemicals LM-123 Spinel................................ 39

54. ASI Stability Data for Japan Metals and Chemicals LM-123 Spinel......................... 39

55. HPPC Test for Seimi Chemical M-216 Spinel................................................ 40

56. Degussa SEPARION Separator............................................................. 41

57. Continuous Coating Process Used to Produce Degussa SEPARION Separator............ 42

58. HPPC Test Data for Cell Employing Degussa SEPARION Separator and Cell Employing Celgard Separator 
59. Relative Peel Strengths of Anodes and Cathodes Made with Different

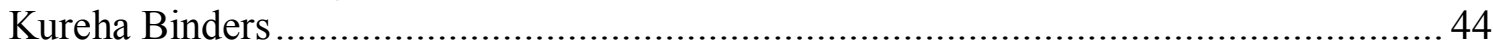

60. SEM Images of Two of the Most Promising Advanced Cell Chemistries ..................... 45

61. HPPC Test Data for Gen 2 Cell Chemistry, Advanced A, and Advanced B Cell Chemistries

62. Comparative DSC Data for Gen 1, Gen 2, and Advanced A Cathodes.........................47

63. DSC Data for Spinel Cathodes at $100 \%$ State of Charge in $1 \mathrm{M} \mathrm{LiPF}_{6}$ in EC:DEC $(1: 1)$

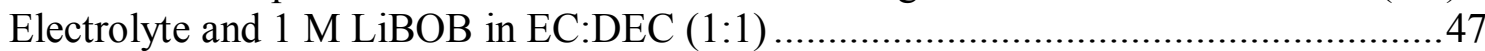

64. Comparative DSC Data for Gen 2 (MAG-10) and GDR Graphite Anodes.....................48

65. DSC Data for Gen 1, Gen 2, and GDR Anode Materials in 1.2 $\mathrm{M} \mathrm{LiPF}_{6}$ in EC:PC:DMC (1:1:3)

66. Potential Battery-Level Material Cost Reductions Using Advanced A and Advanced B Cell Chemistries 



\section{EXECUTIVE SUMMARY}

The U.S. Department of Energy sponsors the Advanced Technology Development (ATD) Program to assist the industrial developers of high-power lithium-ion batteries to overcome the barriers of cost, calendar life, and abuse tolerance so that this technology may be rendered practical for use in hybrid electric vehicles (HEVs) and fuel cell electric vehicles (FCEVs) under the FreedomCAR Partnership. All three of these barriers can be addressed by the choice of materials used in the cell chemistry. Our approach is to obtain the most advanced low-cost materials from international material suppliers and evaluate them for use in high-power HEV and FCEV applications. We develop, refine, and employ standard screening test protocols for the various types of cell materials and components. The results of these screening tests are shared with the international material suppliers, along with recommendations for making their materials and components more optimal for high-power applications. In many cases, we have helped the industrial material suppliers refine their materials for use in HEV and FCEV batteries.

To date, we have developed two high-power cell chemistries, referred to as our Gen 1 and Gen 2 baseline cell chemistries. The Gen 2 cell chemistry offers improvements in cost reduction and longer calendar life relative to the Gen 1 cell chemistry, while the abuse tolerance characteristics of the Gen 1 cell chemistry are slightly better than those of the Gen 2 cell chemistry. For the purpose of our screening tests, we generally employ our Gen 2 cell materials, components, and cell chemistry, as well as their performance levels as the baseline references against which we compare advanced materials, components, and cell chemistries. As an example, we generally employ our Gen 2 electrolyte and cathodes in cells where we assess the power and preliminary aging characteristics of advanced anode materials. In general, we would not evaluate a material that costs as much or more than its Gen 2 counterpart, unless there were opportunities for major cost reductions in the future. When materials appear extremely promising-i.e., when they offer major improvements in cost, life, and inherent safety, relative to our Gen 2 materials - we consider them as viable candidates for use in advanced low-cost cell chemistries. As described in a separate report (Ref. 1), we utilize an ANL-developed battery design/cost model to quantify and track the battery-level cost savings associated with the use of these materials. By combining the results of our screening tests with those of our battery-level design/cost model, we can predict the general benefits (relative to our Gen 2 cell materials) of these new advanced materials and components in the three key areas of cost, life, and inherent safety.

The most recent FreedomCAR energy storage cost goal for HEVs and FCEVs is $\$ 20 / \mathrm{kW}$. Our Gen 2 cell chemistry employs a $\mathrm{LiNi}_{0.8} \mathrm{Co}_{0.15} \mathrm{Al}_{0.05} \mathrm{O}_{2}$ cathode, a synthetic graphite anode, and a $\mathrm{LiPF}_{6}$ in EC:EMC electrolyte. Based on volume production cost estimates for these materials - as well as those for the binders/solvents, cathode conductive additives, separator, and current collectors - the total cell winding material costs for a $25-\mathrm{kW}$ minimum power-assist HEV battery is estimated to be $\$ 399$ (based on our 48-cell battery design, with each cell having a capacity of $15.4 \mathrm{Ah}$ ). This corresponds to $\$ 15.96 / \mathrm{kW}$ just for the cost of the materials in the cell windings. Our goal is to reduce the cell winding material costs to $\leq \$ 10 / \mathrm{kW}$ in order to allow $\geq \$ 10 / \mathrm{kW}$ for the other costs associated with manufacturing the battery, as well as some profit. 
Combining the results of our materials screening work (published herein) with those of our material cost study (published as Ref. 1), we can recommend materials for two low-cost high-power cell chemistries. Our cell chemistry recommendations and battery-level material costs are listed in the following table.

Table ES-1. Recommended Materials for Low-Cost, High-Power Cell Chemistries

\begin{tabular}{|l|l|l|}
\hline & \multicolumn{1}{|c|}{ Advanced A } & Advanced B \\
\hline Cathode & $\mathrm{LiNi}_{1 / 3} \mathrm{Co}_{1 / 3} \mathrm{Mn}_{1 / 3} \mathrm{O}_{2}$ & $\mathrm{LiMn}_{2} \mathrm{O}_{4}$ spinel \\
\hline Anode & Carbon-coated natural graphite & Carbon-coated natural graphite \\
\hline Electrolyte & $\mathrm{LiPF}_{6}$ in EC:PC:DMC & $\mathrm{LiPF}_{6}$ in EC:PC:DMC \\
\hline Cell capacity & $13.8 \mathrm{Ah}$ & $8.5 \mathrm{Ah}$ \\
\hline Material cost & $\$ 12 / \mathrm{kW}$ & $\$ 8.88 / \mathrm{kW}$ \\
\hline
\end{tabular}

Advanced cell chemistry "A" employs a layered cathode active material that employs Mn as a major component and is easily synthesized using low-cost processing. We obtained production cost estimates in the range of $\$ 13-15 / \mathrm{kg}$ for this material, compared with $>\$ 20 / \mathrm{kg}$ for the $\mathrm{LiNi}_{0.8} \mathrm{Co}_{0.2} \mathrm{O}_{2}$-type cathode materials. The $\mathrm{LiMn}_{2} \mathrm{O}_{4}$ spinel cathode material is the lowest cost cathode material at $\$ 7.40 / \mathrm{kg}$. We worked with a graphite supplier to develop a carboncoated natural graphite having a good capacity density, an excellent high-rate capability, and an optimal morphology and particle size. The carbon coating on this material also protects it from exfoliation in PC-based electrolytes. The estimated production cost for this material is $\$ 10 / \mathrm{kg}$, compared with $\$ 15 / \mathrm{kg}$ for the synthetic graphite used in our Gen 2 cell chemistry. Finally, the PC-based electrolyte is estimated to cost $\$ 16 /$ liter, compared with the $\$ 20 /$ liter cost estimated for the electrolyte used in our Gen 2 cell chemistry. Another minor cost saving is associated with the use of an aqueous soft rubber binder in the anodes of the two advanced cell chemistries. Also, additional cost savings should be achievable by changing to a different electrolyte salt. We are currently developing a new solvent system for use with lithium bis(oxalate)borate, a low-cost non-fluorine-containing salt, which is more compatible with the $\mathrm{LiMn}_{2} \mathrm{O}_{4}$ spinel cathode than $\mathrm{LiPF}_{6}$ salt. This new salt, denoted LiBOB, does not react with trace amounts of water or alcohol to form $\mathrm{HF}$, thereby stabilizing the $\mathrm{LiMn}_{2} \mathrm{O}_{4}$ spinel cathode against attack by HF. Use of this new low-cost salt could render the $\mathrm{LiMn}_{2} \mathrm{O}_{4}$ cathode ideal for HEV and FCEV battery applications. The screening test results presented in this report will provide evidence that the performance, life, and inherent safety of the materials used in these two advanced cell chemistries should be superior to those of our Gen 2 cell chemistry.

As described in our materials cost study report (Ref. 1), a cell chemistry based on the use of a $\mathrm{LiMn}_{2} \mathrm{O}_{4}$ spinel cathode material is the lowest cost and meets our battery-level material cost goal of $\leq \$ 10 / \mathrm{kW}$. A major contributing factor is the high-rate capability of this material, which allows one to design a lower capacity cell to meet the battery-level power and energy requirements. This reduces the quantities of the other materials needed to produce a power-assist $\mathrm{HEV}$ or FCEV energy storage battery. Additionally, the $\mathrm{LiMn}_{2} \mathrm{O}_{4}$ spinel cathode is much more thermally and chemically stable than the $\mathrm{LiNi}_{0.8} \mathrm{Co}_{0.2} \mathrm{O}_{2}$-type cathodes and this should enhance the inherent safety and extend the calendar life (if it can be stabilized against dissolution via HF attack). Therefore, we recommend that the FreedomCAR Partnership focus its R\&D efforts on 
developing this type of low-cost high-power lithium-ion cell chemistry. Details supporting this recommendation are provided in the body of this report. 


\section{INTRODUCTION}

The Battery Technology Department at Argonne National Laboratory is a major participant in the U.S. Department of Energy's Advanced Technology Development (ATD) program. This multi-national laboratory program is dedicated to improving lithium-ion batteries for high-power HEV and FCEV applications. As part of the FreedomCAR Partnership, this program is addressing the three key barriers for high-power lithium-ion batteries: calendar life, abuse tolerance, and cost. All three of these barriers can be addressed by the choice of materials used in the cell chemistry. To date, the ATD program has developed two high-power cell chemistries, denoted our Gen 1 and Gen 2 cell chemistries. The selection of materials for use in the Gen 2 cell chemistry was based largely on reducing material cost and extending cell calendar life, relative to our Gen 1 cell chemistry. Table 1 provides a list of the materials used in our Gen 2 cell chemistry and their projected costs, when produced in large-scale quantities.

Table 1. Materials Employed in Gen 2 Cells

\begin{tabular}{|l|l|c|}
\hline \multicolumn{1}{|c|}{ Component } & \multicolumn{1}{|c|}{ Material } & Cost \\
\hline Anode & $92 \mathrm{wt} \%$ MAG-10 graphite & $\$ 15.00 / \mathrm{kg}$ \\
& $8 \mathrm{wt} \%$ PVDF binder & $\$ 10.00 / \mathrm{kg}$ \\
\hline Cathode & $84 \mathrm{wt} \% \mathrm{LiNi}_{0.8} \mathrm{Co}_{0.15} \mathrm{Al}_{0.05} \mathrm{O}_{2}$ & $\$ 20.52 / \mathrm{kg}$ \\
& $4 \mathrm{wt} \% \mathrm{SFG}-6$ graphite & $\$ 15.00 / \mathrm{kg}$ \\
& $4 \mathrm{wt} \%$ carbon black & $\$ 6.82 / \mathrm{kg}$ \\
& $8 \mathrm{wt} \% \mathrm{PVDF}$ binder & $\$ 10.00 / \mathrm{kg}$ \\
\hline Electrolyte & $1.2 \mathrm{M} \mathrm{LiPF}_{6}$ in EC:EMC (3:7) & $\$ 20.00 / \mathrm{L}$ \\
\hline
\end{tabular}

In evaluating advanced materials, we have focused our efforts on materials that are lower cost than those listed in Table 1, while simultaneously offering enhanced chemical, structural, and thermal stability. Therefore, we have focused on natural graphite anode materials (having round-edge particle morphologies), cathode materials that contain more $\mathrm{Mn}$ and less $\mathrm{Co}$ and $\mathrm{Ni}$ (which can be produced via low-cost processes), lower cost electrode binders and/or binders that possess superior bonding properties at lower concentrations, and lower cost salts and solvents (with superior thermal and oxidation/reduction stability) for use in the electrolyte.

\section{$1.1 \quad$ SCOPE OF REPORT}

The purpose of this report is to document the results of screening tests that were performed on a large number of advanced low-cost materials. These materials were screened for their potential to impact positively on the calendar life, safety, and/or cost of high-power lithiumion cell chemistries, relative to our Gen 2 cell chemistry. As part of this effort, we developed and employed a set of standard test protocols to evaluate all of the materials. After brief descriptions of the screening test methodologies and equipment, relevant data on each material are summarized in the body of this report.

We have evaluated five categories of materials, and the report is organized accordingly. Results will be presented on advanced carbons for anodes, improved cathode materials, new salts and solvent systems, alternative binders, and novel separators. 
A key feature to this work involves the close interaction of Argonne National Laboratory (ANL) with industrial material suppliers to help them refine their advanced materials and tailor them for use in high-power lithium-ion batteries. ANL utilizes a wide range of electrochemical, chemical, thermal, physical, and modeling techniques to evaluate the strengths and weaknesses of each material and then provides recommendations to the material suppliers on ways to improve their materials for use in high-power cells and batteries. This method of evaluating materials and recommending ways to improve them (repeated as necessary) has led to significant advances in lithium ion-battery materials for high-power applications.

Several examples of significant advancements, resulting from this method of operating, appear in this report. The development of an advanced natural graphite by Mitsui is an example of one major success. The initial flaky graphite produced by Mitsui was unsuitable for this application in the areas of safety and calendar life. The interaction with Argonne led to the evolution of their material to a spherical morphology that contained a soft carbon coating. These properties were verified by scanning electron microscopy (SEM) and transmission electron microscopy (TEM). Also, the particle size distribution was optimized for the high-power HEV application. The final carbon material has demonstrated outstanding electrochemical performance in hybrid pulse power characterization (HPPC) tests, as well as improvements in safety and calendar life. Other highlights include the development of advanced cathode materials with Fuji and Seimi. Argonne's interaction with these companies included similar morphology and particle size optimizations. Also involved were modifications in material compositions by adjusting dopant levels in these materials. Several promising advanced cathode materials have emerged from these cooperative studies.

Argonne continues to work closely with companies producing anode, cathode, electrolyte salt, electrolyte, separator, and binder materials to tailor their products for high-power HEV, 42volt, and FCEV battery applications.

\subsection{TECHNIQUES AND METHODS}

A vast array of diagnostic techniques and chemical analysis methods have been employed to fully characterize all of the materials in this study. This section provides a brief summary of the typical experimental techniques used in this study and the types of information obtained.

Electrochemical Evaluation: The electrochemical performance of materials is examined using a range of measurement techniques. Electrochemical cycling is used to establish capacity, power characteristics, and impedance, as well as to measure changes in these parameters resulting from elevated temperature aging. Cyclic voltammetry is used to establish oxidationreduction profiles and to investigate the reversibility of the electrochemical reactions with these electrode materials. The FreedomCAR HPPC test is used to mimic the high-power demands that would be placed on a battery during real driving conditions.

Electron Microscopy Techniques: SEM and TEM techniques are used to gain an understanding of materials at the particle or atomic level. Initial morphologies and changes in morphology that occur during electrochemical cycling and/or aging can be established. The 
addition of EDX (energy dispersive x-ray) analysis allows for an examination of purity. It is possible in some cases to observe localized effects, such as exfoliation at an edge or the emergence of a secondary phase.

Thermal Techniques: TG/DTA (thermo-gravimetric/differential thermal analysis) and DSC (differential scanning calorimetry) provide information on temperatures at which reactions occur, as well as a relative measure of the safety associated with the chemical reactivity of the materials. The onset of an exotherm or endotherm can be established and quantified. The technique of accelerating rate calorimetry (ARC) is employed to characterize the thermal runaway process associated with each different cell chemistry.

Chemical Methods: As needed, traditional chemical methods are employed to fully characterize materials. ICP (inductively coupled plasma) and AA (atomic absorption) spectrometries provide elemental analyses that give exact chemical compositions, which are potentially very useful for studying material changes resulting from cycle testing and aging. ICP and AA are also used to determine the concentrations of impurities in the electrolyte after electrode leaching tests at elevated temperatures. The use of x-ray diffraction is important for phase identification and purity determination, as well as for special orientation effects that may be present. When developing novel electrolyte compositions, the measurement of electrical conductivity is also an important parameter to determine.

Miscellaneous Experiments: A large number of specialized experiments can be designed when more detailed information is required. The Advanced Photon Source at Argonne provides synchrotron radiation for EXAFS (extended x-ray absorption fine structure) studies that yield structural information about materials. These measurements can be made directly on materials, in addition to advanced experiments in which EXAFS and x-ray diffraction data can be obtained in situ as the materials are electrochemically cycled. Several spectroscopic methods have also been employed to investigate various aspects of cell chemistry and material interactions. Examples include infrared and nuclear magnetic resonance spectroscopy.

Electrode Preparation and Cell Testing: Electrodes are typically prepared as an NMP (1-methyl-2-pyrrolidinone) slurry consisting of the active material, binder, and conductive additive (for the cathode); the slurry is cast as a film (between 100 and $200 \mu \mathrm{m}$ thick) onto aluminum foil for the cathode and copper foil for the anode. The NMP solvent is evaporated in a convection oven at elevated temperature and then the laminates are calendared in the dry condition and allowed to further dry in a vacuum oven for several hours before being used in cell construction. Two types of cells are commonly constructed: a 2032 coin cell, for most of the routine electrochemical evaluations, and an ANL-designed 32- $\mathrm{cm}^{2}$ lab cell, for HPPC tests. Special pouch cells are prepared for synchrotron experiments. Materials are screened in half cells that use metallic lithium counter electrodes for capacity evaluations and in the full-cell configurations for preliminary aging and HPPC (power characterization) tests.

Equipment Used: Table 2 lists the equipment used to carry out the types of experiments that have been described. 
Table 2. Equipment Used to Carry Out Experiments

\begin{tabular}{|l|l|l|}
\hline \multicolumn{1}{|c|}{ Equipment } & \multicolumn{1}{c|}{ Manufacturer } & \multicolumn{1}{c|}{ Model } \\
\hline Powder diffractometer & Siemens & D5000 \\
\hline Electrochemical test unit & Maccor & Series 2000 \\
\hline $\begin{array}{l}\text { Cyclic voltameter } \\
\text { (potentiostat/galvanostat) }\end{array}$ & Princeton Applied Research & 273A \\
\hline $\begin{array}{l}\text { Differential scanning } \\
\text { calorimeter }\end{array}$ & Perkin Elmer & Pyris 1 \\
\hline $\begin{array}{l}\text { Thermal } \\
\text { gravimetric/differential } \\
\text { thermal analysis) }\end{array}$ & Seiko Instruments & Exstar 6000 \\
\hline ARC calorimeter & Columbia Scientific & ARC-2000 \\
\hline $\begin{array}{l}\text { Atomic absorption } \\
\text { spectrometer }\end{array}$ & Perkin Elmer & AAnalyst 100 \\
\hline Scanning electron microscope & JEOL & JSM 640 \\
\hline $\begin{array}{l}\text { Transmission electron } \\
\text { microscope }\end{array}$ & JEOL & JEOL 4000EX \\
\hline Conductivity instrument & YSI & 3200 \\
\hline
\end{tabular}




\section{COMPONENT TESTING PROTOCOLS}

\section{$2.1 \quad$ RAPID SCREENING TECHNIQUES}

Cathode and Anode

Step 1: Check morphology and particle size via SEM.

Step 2: Electrode processing.

Step 3: Initial electrochemical characterization by 2032 coin cell tests.

Step 4: HPPC test using ANL cell fixture.

Step 5: Three-week accelerated aging at $100 \%$ SOC and $50-55^{\circ} \mathrm{C}$.

Step 6: Quick safety study using DSC (100\% SOC).

Step 7: Provide information directly to FreedomCAR industrial battery developers.

Step 8: Provide samples of promising materials to FreedomCAR industrial battery developers upon request.

Binder

Step 1: Electrode processing using the new binder and Gen 2 materials.

Step 2: Check binding strength and compare with PVDF.

Step 3: Quick HPPC test to check the effect of binder on power performance.

Step 4: Investigate binder reactivity with active materials using DSC (100\% SOC).

Step 5: Provide information directly to FreedomCAR industrial battery developers.

Step 6: Provide samples of promising materials to FreedomCAR industrial battery developers upon request.

Electrolyte and Additives

Step 1: Quick electrochemical and HPPC tests to study effects on power (using Gen 2 electrodes).

Step 2: Investigate additive effects on preventing exfoliation of graphite in the presence of propylene carbonate.

Step 3: Two-week accelerated aging at $100 \%$ SOC and $55^{\circ} \mathrm{C}$ to study the additive effect on system stability.

Step 4: Investigate additive effect on safety via DSC and ARC.

Step 5: Investigate additive effect on cell gassing.

Step 6: Provide information directly to FreedomCAR industrial battery developers.

Step 7: Provide samples of promising materials to FreedomCAR industrial battery developers upon request.

Flame Retardants

Step 1: Flame propagation test using Gen 2 and advanced ternary electrolytes.

Step 2: DSC study of Gen 2 electrodes and full cell at $100 \%$ SOC with and without flame retardant. 
Step 3: ARC study of Gen 2 electrodes and full cell at 100\% SOC with and without flame retardant.

Step 4: Provide information directly to FreedomCAR industrial battery developers.

Step 5: Provide samples of promising flame retardants to FreedomCAR industrial developers upon request. 


\section{ADVANCED CARBON ANODES}

Criteria Governing the Choice of Carbon

A successful candidate material must exhibit the following properties:

- Low cost (less than $\$ 10 / \mathrm{kg}$ ).

- Optimized morphology for improved safety and long calendar life.

- Correct morphology and chemical treatment to produce a uniform passivation film.

- Better performance (cell ASI less than $35 \mathrm{ohm}-\mathrm{cm}^{2}$ ) and aging characteristics.

\section{Development Strategy}

- The industry standard MCMB has a spherical morphology that is desirable in the formation of a uniform passivation film; however, the material is expensive at $\sim \$ 50 / \mathrm{kg}$.

- Our strategy is to evaluate natural graphite materials that are less expensive $(\$ 5-10 / \mathrm{kg})$.

- Additionally, we work with carbon suppliers to optimize the particle size, morphology, and surface treatment of natural graphite materials to meet our cost, safety, and calendar life goals.

\section{Desirable Characteristics for Enhanced Safety}

Carbon morphology has a major effect on safety. Extensive testing has shown that a spherical morphology with uniform particle size is preferred. The rounded edges exemplified by GDR-AA-2 (Fig. 1a) have significant safety performance improvements as measured by DSC compared with flaky particles (Fig. 1b) with highly reactive edges, GDA-2-1. Flaky morphologies are susceptible to easy decomposition of the passivation film, which can lead to very large heat generation and possible thermal runaway. A much safer uniform passivation film is produced and retained with spherical particles.

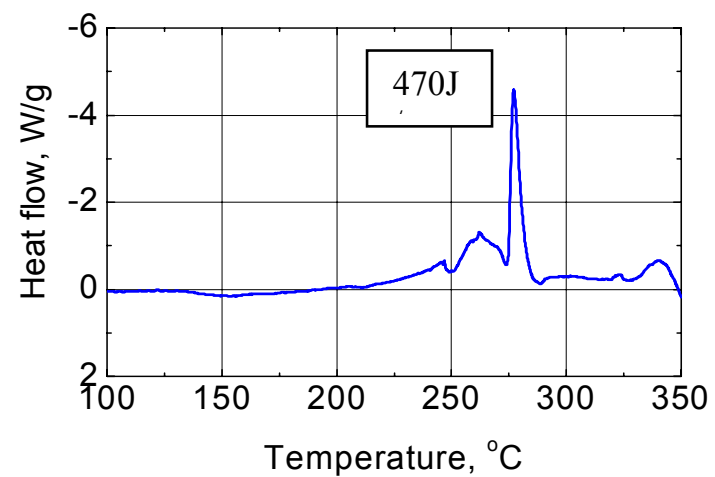

(a)

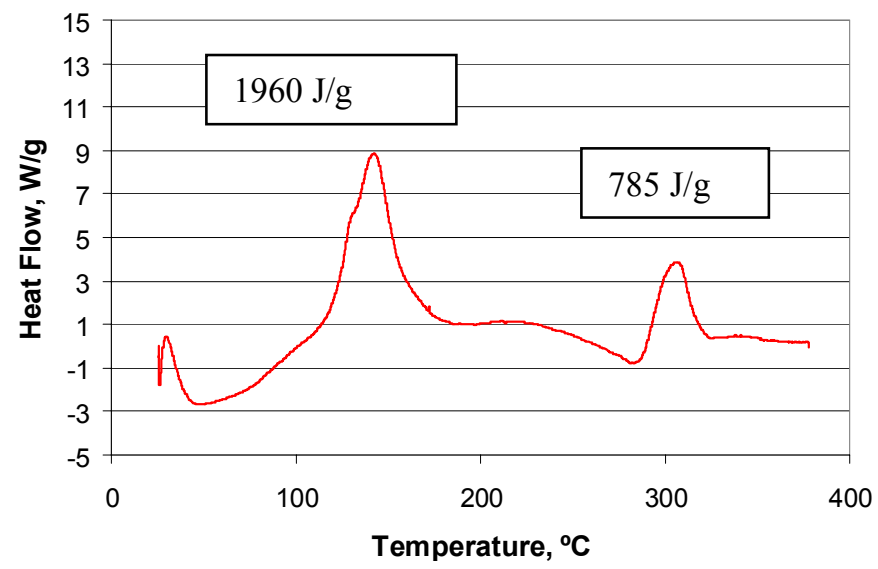

(b)

Fig. 1. DSC for (a) GDR-AA-2 and (b) GDA-2-1 


\section{Desirable Characteristics for Long Life}

Morphology of the carbon also significantly impacts calendar life. A substantial improvement, as measured by ASI, is evident when comparing a sample of GDR-A-2 with spherical morphology (Fig. 2a) with a flaky carbon anode sample, GDA-2-1 (Fig. 2b). The large concentration of sharp reactive edges in the flaky sample results in increased reactivity at the electrolyte interface, which results in higher impedance growth in the cell.

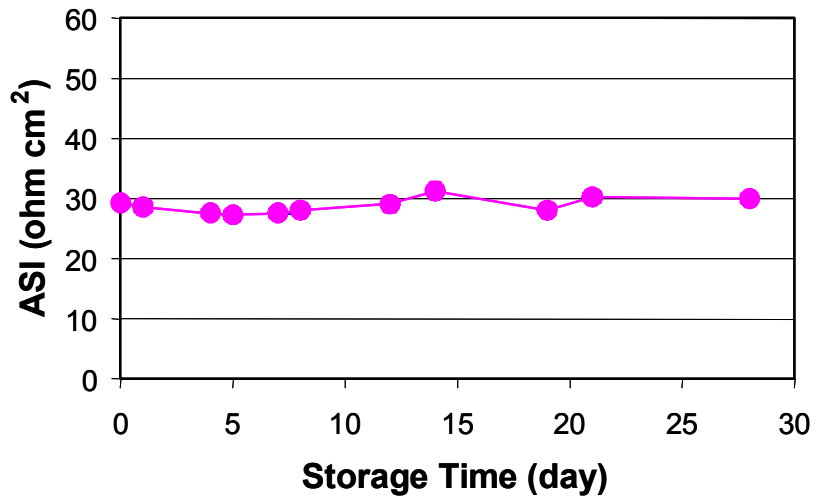

(a)

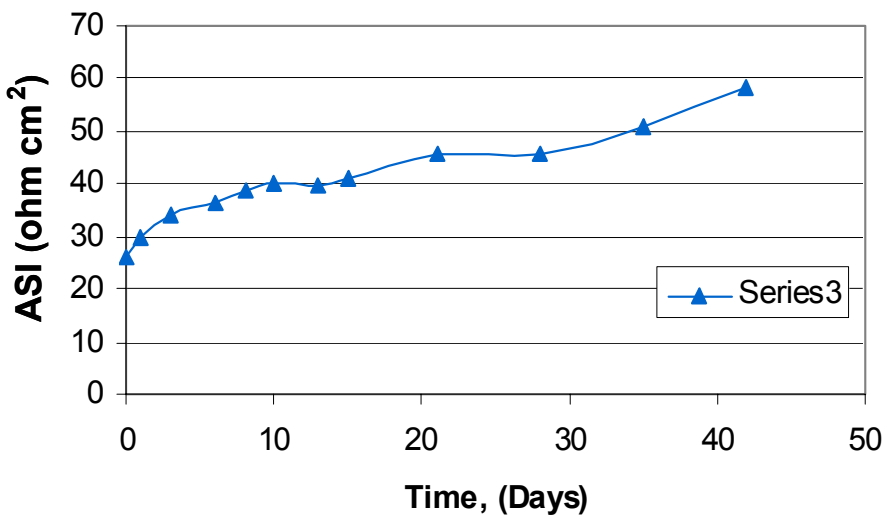

(b)

Fig. 2. ASI vs. Time $\left(100 \% \mathrm{SOC}, 50^{\circ} \mathrm{C}\right)$ for (a) GDR-A-2 and (b) GDA-2-1

\section{$\underline{\text { Anode Graphite Cost Information }}$}

Table 3 summarizes cost information for our Gen 2 anode material (MAG) and several natural graphites that we evaluated over the last year. The MAG is a synthetic graphite, while all others are natural graphites with rounded-edge morphologies. The GDR material contains a soft carbon coating at the particle level.

Table 3. High-Volume Cost Projections for Gen 2 Anode Materials and Graphite Materials

\begin{tabular}{|l|l|c|}
\hline \multicolumn{1}{|c|}{ Industrial Supplier } & \multicolumn{1}{c|}{ Anode Material } & $\begin{array}{c}\text { Estimated Cost } \\
\mathbf{( \$ / k g )}\end{array}$ \\
\hline Hitachi & (MAG) Synthetic graphite & 15.00 \\
\hline Mitsui Mining & (GDR) Carbon-coated natural graphite & 10.00 \\
\hline Superior Graphite & (SLC) Natural graphite & 10.00 \\
\hline Diabeck & (DJG) Natural graphite & 6.00 \\
\hline Timical & (E-SLP) Natural graphite & 6.00 \\
\hline SLC & (SLC) Natural graphite & 5.00 \\
\hline
\end{tabular}




\subsection{MITSUI MINING MATERIAL CO., LTD.}

\section{$\underline{\text { Contact Information }}$}

H. Miyama

Mitsui Mining Material Co., Ltd.

3-3, Toyosu 3-chome, Koto-Ku

Tokyo, 135-6006 Japan

Tel: $\quad 81-3-5560-2114$

Fax: 81-3-5560-2192

Material Data

Grade: GDR-AA-2

Physical analysis

Surface area $\left(\mathrm{m}^{2} / \mathrm{g}\right) \quad 1.7$

Tap density $(\mathrm{g} / \mathrm{mL}) \quad 0.93$

Particle size distribution by laser diffraction

D-10 $(\mu \mathrm{m}) \quad 14.5$

D-50 $(\mu \mathrm{m}) \quad 26.6$

D-90 $(\mu \mathrm{m}) \quad 38.6$

Collaborative Effort to Optimize GDR for High-Power Applications

Carbon materials are commonly used as the negative electrode in lithium-ion cells. Among the various carbon materials, natural graphite shows promise because it has a high capacity (372 Ah/kg), low redox potential, relatively flat potential profile, and low cost. However, the use of natural graphite is limited by its sensitivity to certain electrolytes. Natural graphite electrodes are not compatible with propylene carbonate (PC)-based electrolytes, which have a lower melting point and better safety characteristics than other commonly used organic carbonate solvents. The problem is that $\mathrm{PC}$ solvent molecules co-intercalate with $\mathrm{Li}^{+}$into the graphite, frequently leading to exfoliation of the graphite matrix.

In an effort to solve this problem, surface-modified natural graphite was obtained from Mitsui Mining Co. Ltd. The particle surfaces are coated with soft carbon using a thermal vapor deposition (TVD) technique. The performance of these TVD-coated graphites in PC-based electrolytes was evaluated using our standard test protocols. GDA was the first type of material supplied by Mitsui for our evaluation. The amorphous soft carbon coating over natural graphite can be clearly seen by high-resolution TEM, as shown in Figure 3. 


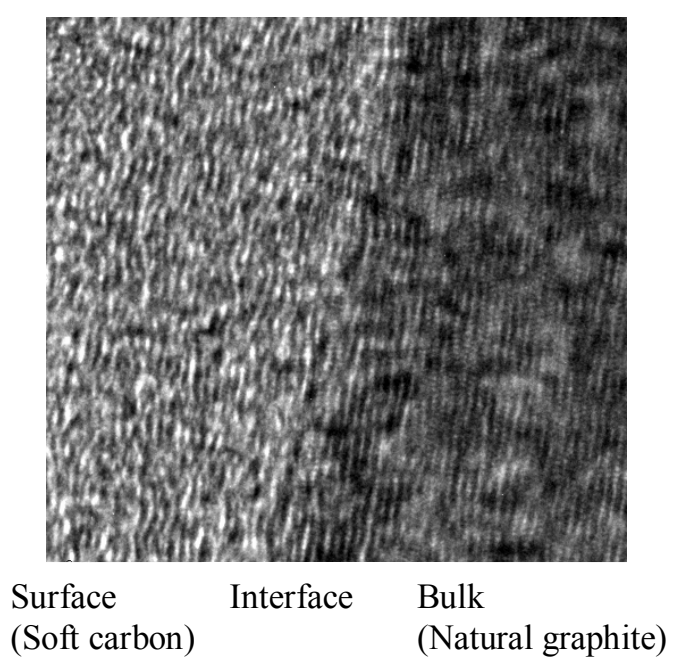

Fig. 3. HR-TEM of Mitsui Mining GDA-N2-3 Cross Section

However, the GDA was a flake-type graphite, which is nonoptimal from a safety perspective. So ANL worked closely with Mitsui to help tailor its carbon products for our highpower HEV application-mainly to enhance safety and calendar life. GDR is the advanced graphite with round-edge morphology that resulted from this interaction. Among the various samples from Mitsui, GDR-AA-3 is a natural graphite with a soft carbon coating and the proper particle size distribution. The amorphous carbon coating at the particle surface prevents exfoliation of the GDR graphite in PC-based electrolytes. Figure $4 \mathrm{a}$ shows the initial morphology and particle size. Significant improvements are obtained by reducing the particle size to the dimensions shown in Figure $4 b$.

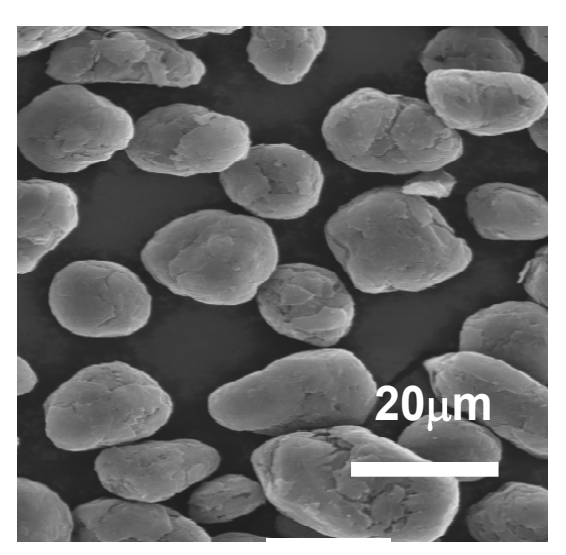

(a)

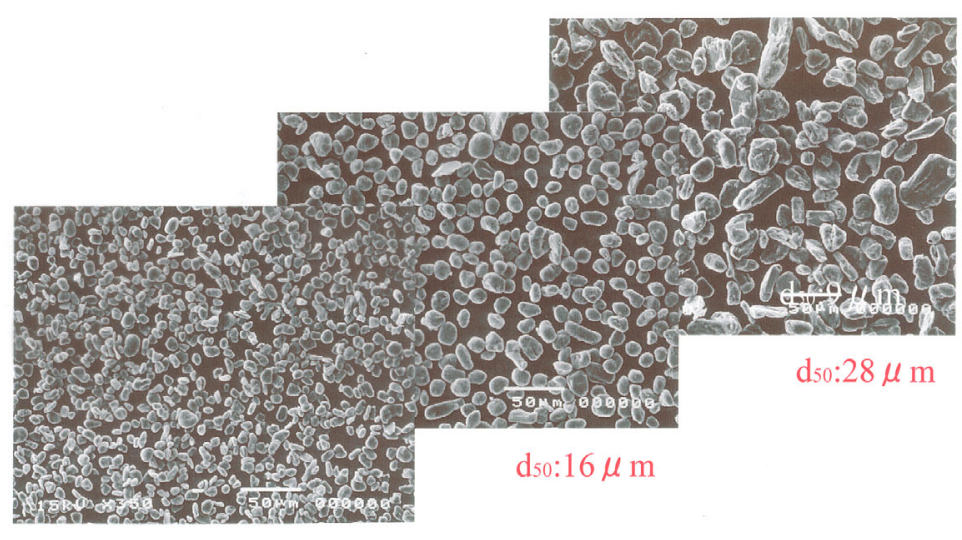

(b)

Fig. 4. (a) SEM of Mitsui Mining Initial GDR-AA-3 and (b) Improvements Obtained by Optimizing Particle Size. The $\mathrm{d}_{50}=16 \mu \mathrm{m}$ particle size is optimal. 


\section{Electrochemical Performance Characteristics}

The initial capacity stability of the GDR (Fig. 5) is very good. The cell configuration is GDR(-) and Gen 2(+) with LP40 electrolyte. Most impressive is the performance of this material in a HPPC test, where we obtained the lowest ASI to date (Figs. 6 and 7).

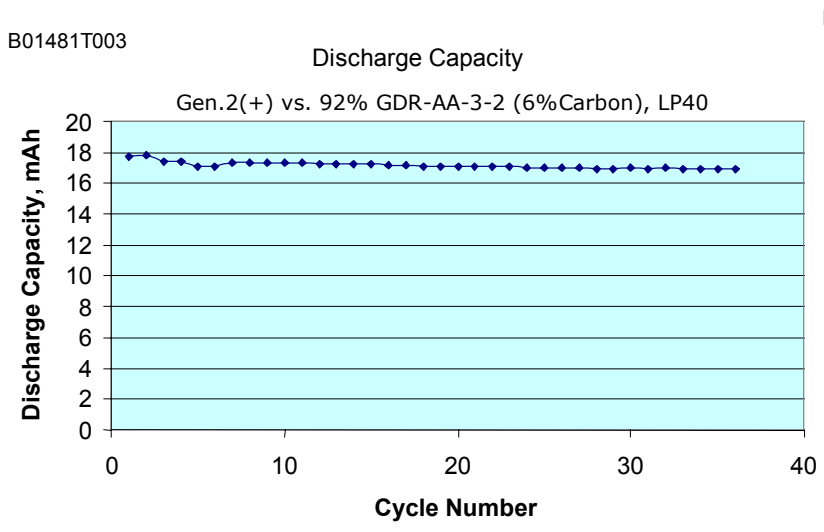

Fig. 5. Initial Capacity Stability Data for Mitsui Mining GDR-AA-3

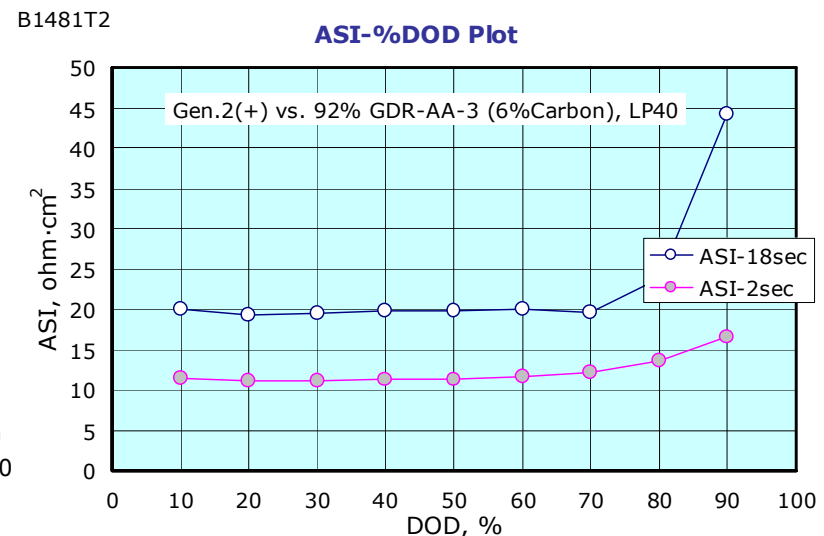

Fig. 6. 10C Rate HPPC Test Data for Mitsui Mining GDR-AA-3

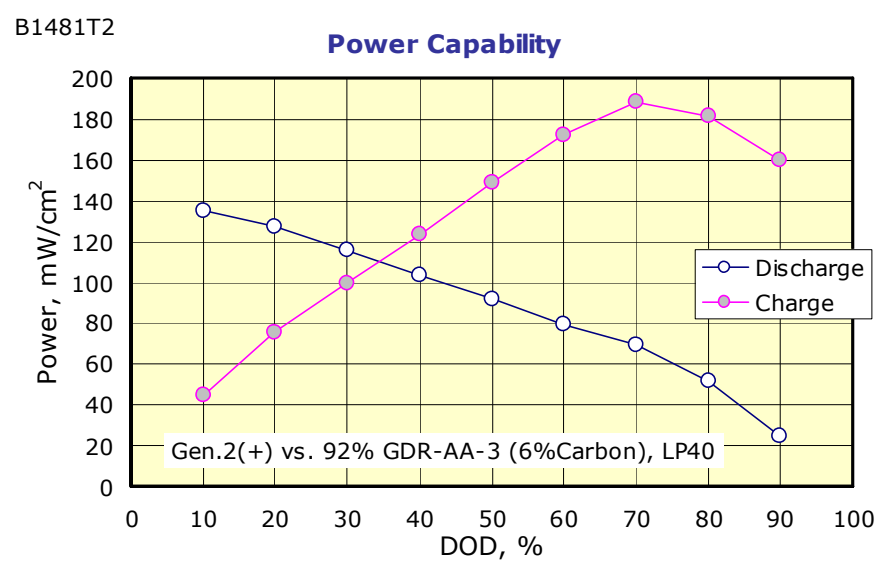

Fig. 7. Power Capability for Mitsui Mining GDR-AA-3 Calculated from HPPC Data

\section{Preliminary Accelerated Aging Characteristics}

The preliminary accelerated aging characteristics of GDR are better than those for MAG-10 (the Gen 2 graphite) and even better than those for the much more expensive MCMB (the Gen 1 graphite) (Fig. 8).

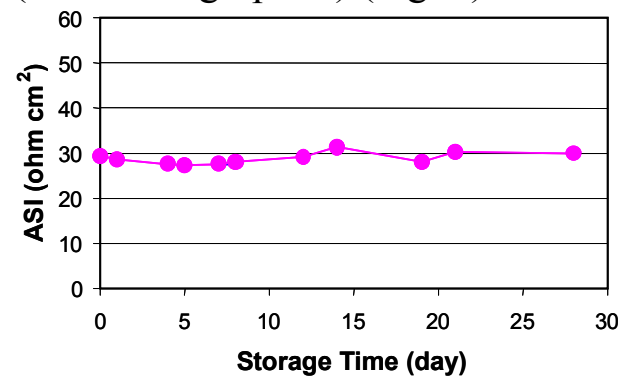

Fig. 8. ASI Values for Mitsui Mining GDR-AA-3 During Aggressive Aging $\left(100 \% \mathrm{SOC}, 50^{\circ} \mathrm{C}\right)$ 


\subsection{DAIBECK ADVANCED MATERIALS CO., LTD.}

\section{$\underline{\text { Contact Information }}$}

Leeki Lee

Daibeck Advanced Materials Co., Ltd.

990-3, Madu-Dong, Ilsan-Gu

Goyang City

Kyunggi-Do, Korea

Tel: $\quad$ (82-31) 900-1616

Fax: (82-2) 2645-1873

E-mail: $\quad$ leeki@daibeck.co.kr

Internet: www.daibeck.co.kr

Material Data

Grade: DJG New 3 (Amorphous carbon coated natural graphite)

Physical analysis

Surface area $\left(\mathrm{m}^{2} / \mathrm{g}\right) \quad 2.8-3.2$

Tap density $(\mathrm{g} / \mathrm{mL}) \quad 0.981-0.985$

Bulk density $(\mathrm{g} / \mathrm{mL}) \quad 0.54$

Particle size distribution by laser diffraction

D-10 $(\mu \mathrm{m}) \quad 9.8-10.5$

D-50 $(\mu \mathrm{m}) \quad 20.3-20.8$

D-90 $(\mu \mathrm{m}) \quad 39.3-39.8$

Electrochemical Performance Characteristics

This material has acceptable performance in HPPC tests, as shown in Figures 9 and 11. It also demonstrates good capacity stability, as shown in Figure 10, and costs less than $\$ 10 / \mathrm{kg}$. 


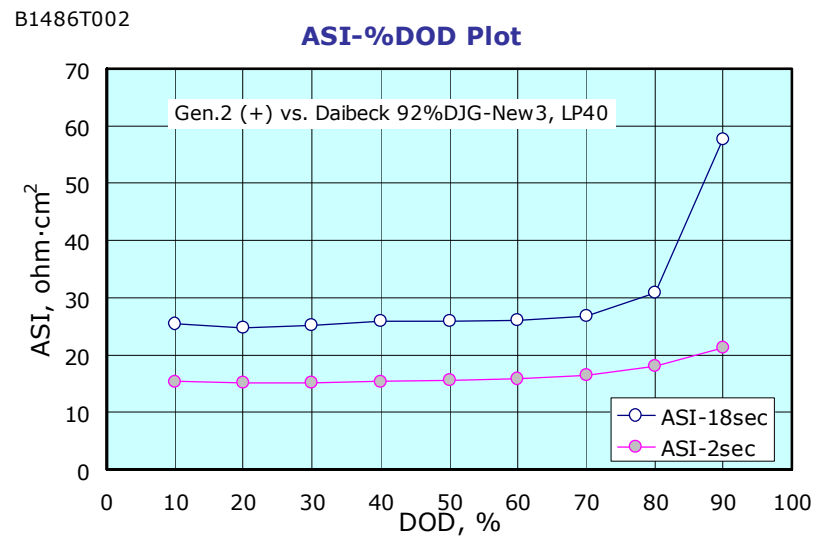

Fig. 9. HPPC Test Data for Daibeck Advanced Materials DJG Graphite

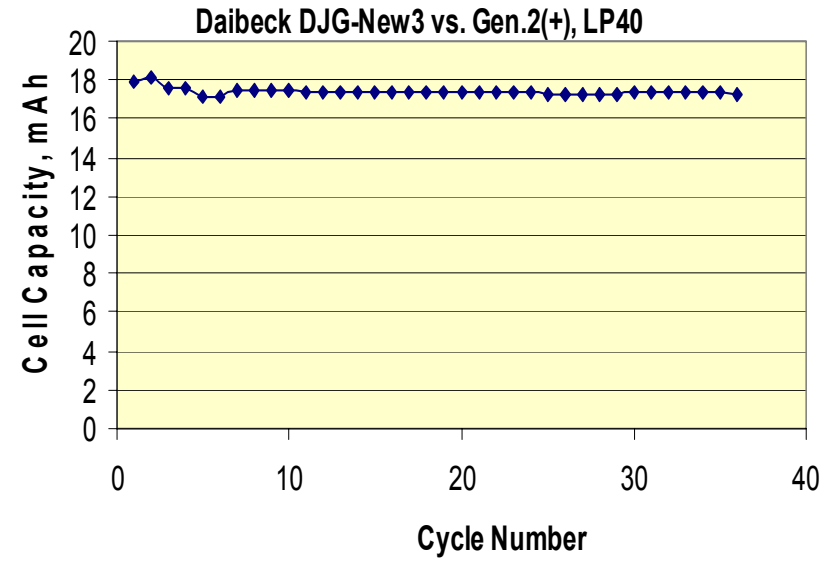

Fig. 10. Initial Capacity Stability Data for Daibeck Advanced Materials DJG Graphite

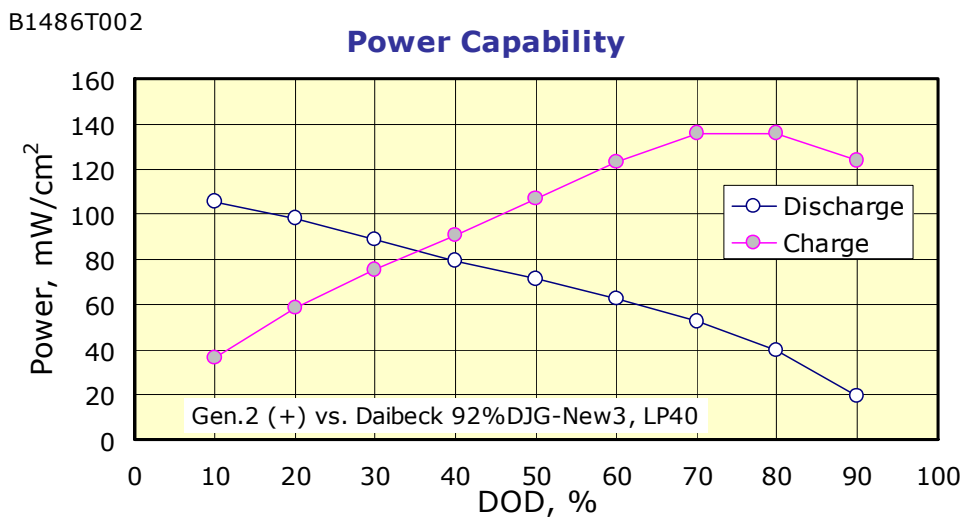

Fig. 11. Power Capability for Daibeck Advanced Materials DJG New 3 Graphite Calculated from HPPC Data

Preliminary Accelerated Aging and Safety Characteristics

The Daibeck carbon-coated NG (DJG New 3) sample also shows excellent behavior upon aging (Fig. 12). Figure 13 shows the thermal effects in a DSC scan obtained on the material at $100 \%$ SOC. 


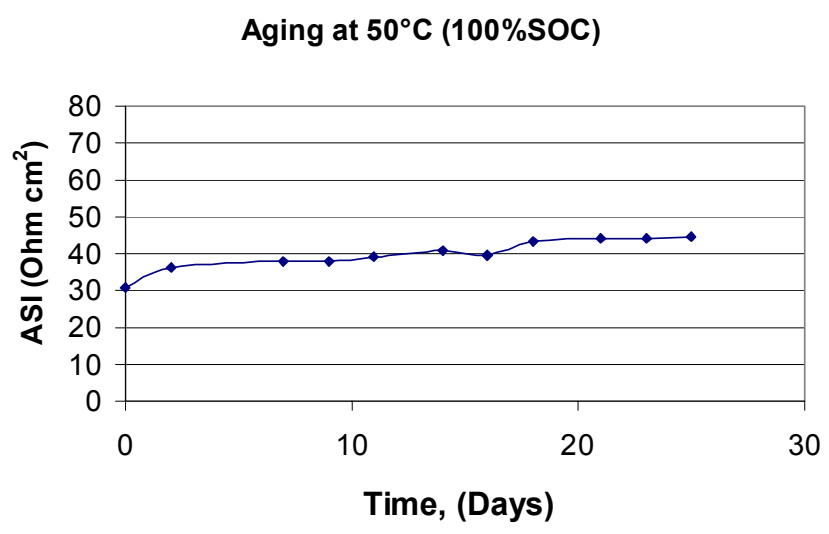

Fig. 12. ASI vs. Time for Daibeck Advanced Materials DJG New 3

\subsection{BEIJING ADVANCED MATERIALS}

\section{Contact Information}

Stephen Pred

Pred Materials International (vender)

The Lincoln Building

60 East 42nd St., Suite 1456

New York, NY 10165

Tel: $\quad 212-286-0068$

Fax: 212-286-0072

Material Data

Grade: SLC 10U Chinese graphite

Physical analysis

Surface area $\left(\mathrm{m}^{2} / \mathrm{g}\right) \quad$ NA

Tap density $(\mathrm{g} / \mathrm{mL}) \quad$ NA

Particle size distribution by laser diffraction

$\begin{array}{ll}\text { D-10 }(\mu \mathrm{m}) & \text { NA } \\ \text { D-50 }(\mu \mathrm{m}) & 11.66 \\ \text { D-90 }(\mu \mathrm{m}) & \text { NA }\end{array}$

\section{Particle Size and Shape}

This natural graphite is a very inexpensive carbon alternative, priced at $\sim \$ 5 / \mathrm{kg}$. Figure 14 shows the round-edge and uniform spherical morphology of this material. 


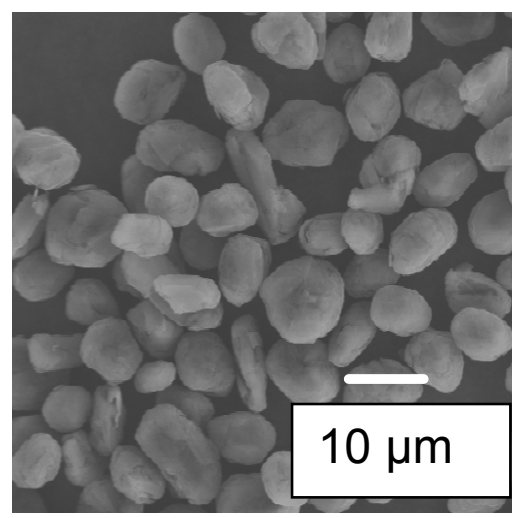

Fig. 14. SEM Image of Beijing Advanced Materials SLC 10U

\section{$\underline{\text { Electrochemical Performance Characteristics }}$}

The SLC 10U natural graphite has excellent high-power characteristics for our HEV application, as shown in Figures 15 and 16.

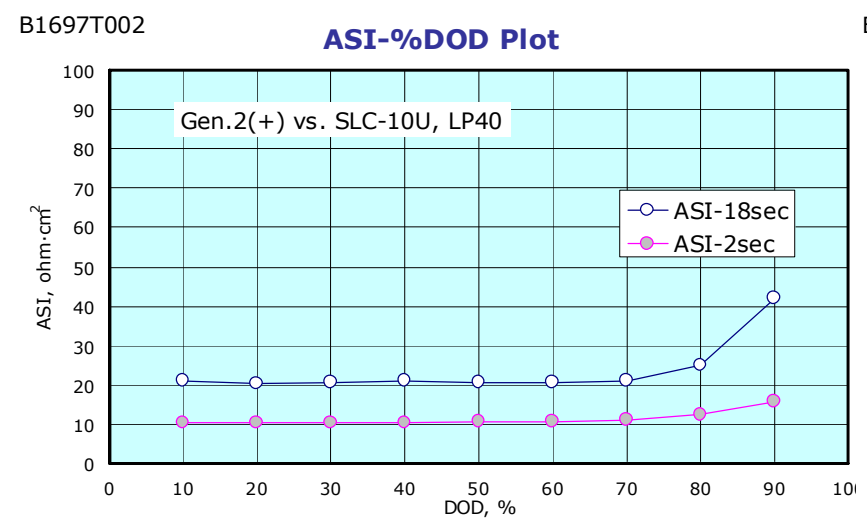

Fig. 15. HPPC Test Data for Beijing Advanced Materials SLC 10U

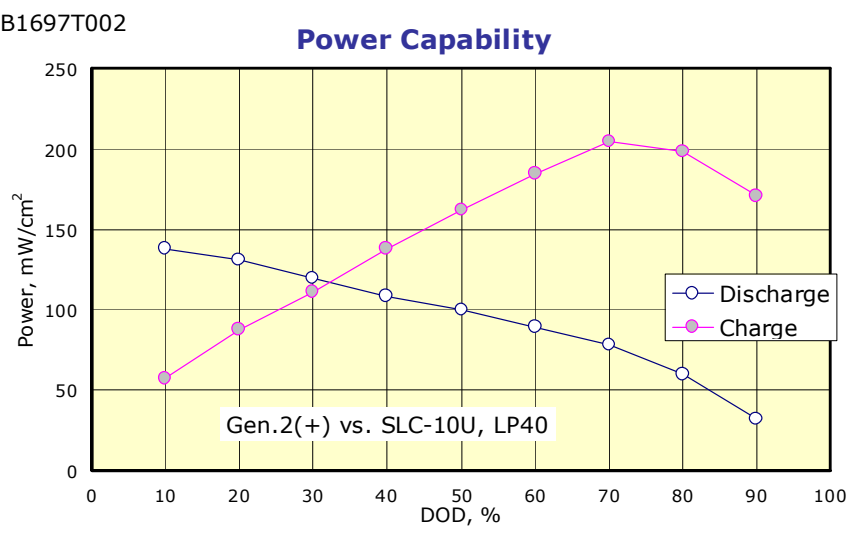

Fig. 16. Power Capability for Beijing Advanced Materials SLC 10U Calculated from HPPC Data

\section{Preliminary Accelerated Aging and Safety Characteristics}

The accelerated aging behavior of this material at $100 \% \mathrm{SOC}$ and $50^{\circ} \mathrm{C}$ is very good, as shown by Figure 17. The thermal characteristics of this material are also good, as shown by Figure 18. 


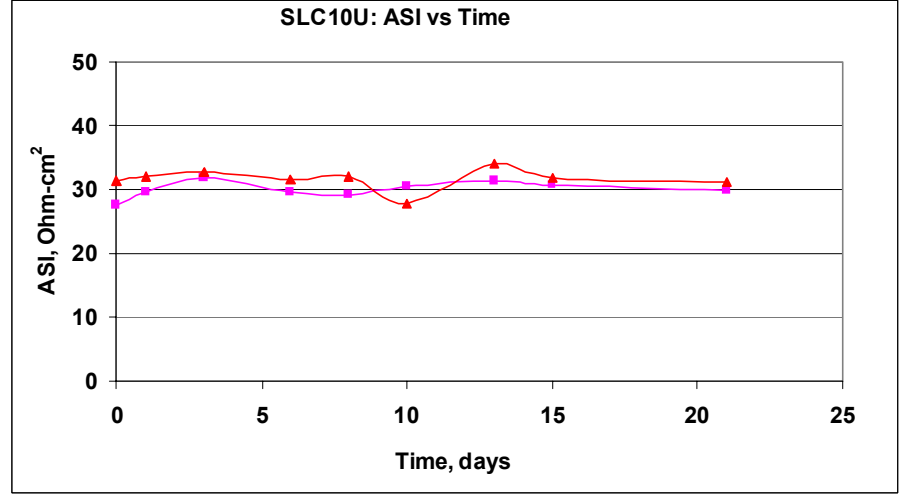

Fig. 17. Variation of ASI vs. Time for Beijing Advanced Materials SLC 10U

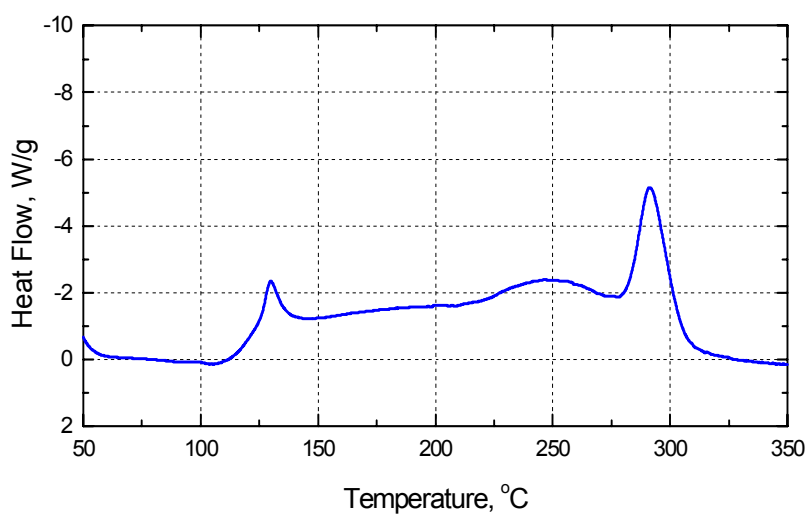

Fig. 18. DSC for Beijing Advanced Materials SCL 10U

\subsection{SUPERIOR GRAPHITE}

\section{Contact Information}

Igor Barsukov

Superior Graphite Co.

4201 W. $36^{\text {th }}$ Street

Chicago, IL 60632

Tel: $\quad 773-890-4117$

Fax: $\quad 773-890-4121$

Internet: www.graphite SGC.com

$\underline{\text { Material Data }}$

Grade: SLC 1015

Physical Analysis

Surface Area $\left(\mathrm{m}^{2} / \mathrm{g}\right) \quad 1.42$

Tap Density $(\mathrm{g} / \mathrm{mL}) \quad 0.8$

\section{$\underline{\text { Particle Size Distribution }}$}

D-10 $(\mu \mathrm{m}) \quad 8.6$

D-50 $(\mu \mathrm{m}) \quad 14$

D-90 $(\mu \mathrm{m}) \quad 25$

Electrochemical Performance and Preliminary Safety Characteristics

This Superior Graphite grade SLC 1015 round-edge natural graphite exhibits very good power characteristics during HPPC tests, at the 10C pulse rate, as shown in Figure 19. This material also possesses good thermal safety characteristics [with 1.2 M LiPF 6 (EC:PC:DMC) 
(1:1:3) electrolyte], as shown in Figure 20. In prior years, ANL worked with Superior Graphite to help move it to a material that possesses the proper particle size and morphology for this application.

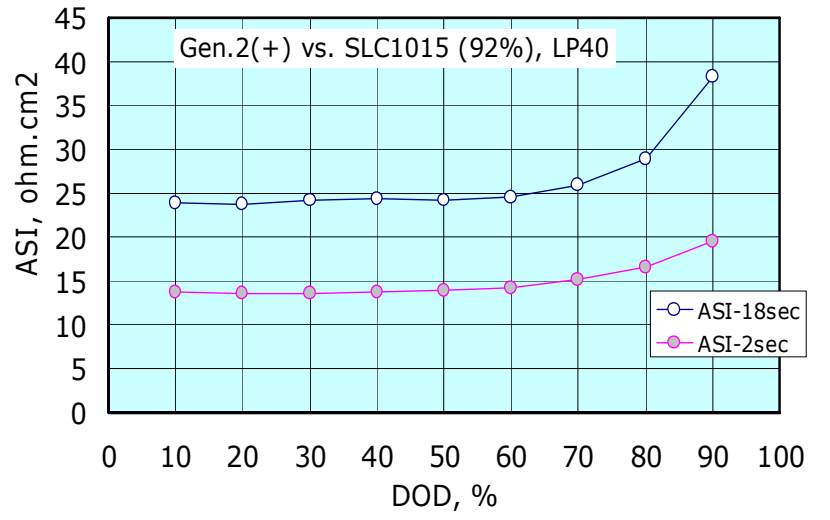

Fig. 19. HPPC Test Data for Superior Graphite SLC 1015

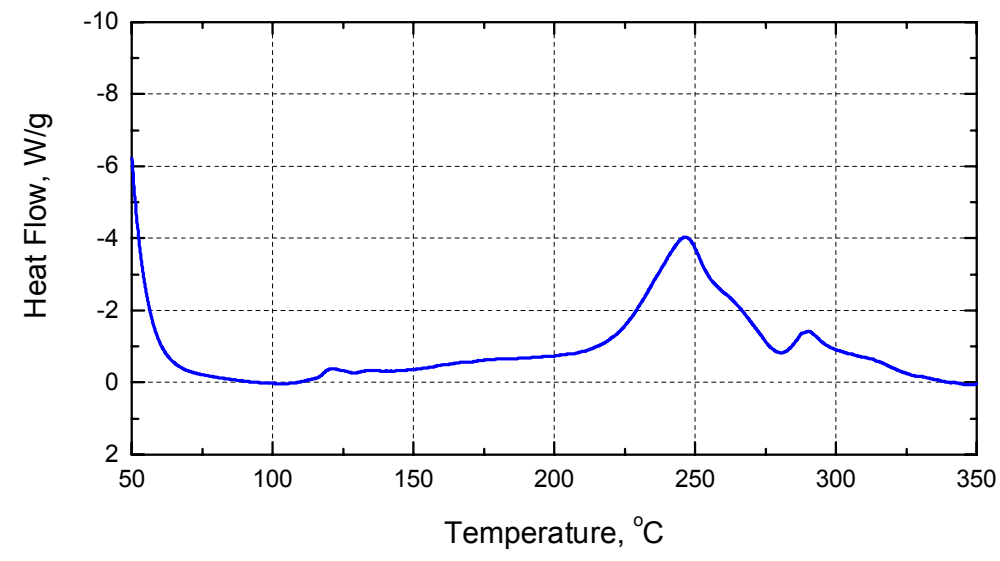

Fig. 20. DSC Data for Superior Graphite SLC 1015

\subsection{SCHUNK GRAPHITE TECHNOLOGY}

\section{Contact Information}

Michaela Baker

Schunk Graphite Technology

W146 N9300 Held Drive

Menomonee Falls, WI 53051-1643

Tel: $\quad 262-250-8869$

Fax: 262-255-1391

E-mail: michaela@schunkgraphite.com

Material Data

Grade: FU 2651

Physical analysis

Surface area $\left(\mathrm{m}^{2} / \mathrm{g}\right) \quad 2$

Tap density $(\mathrm{g} / \mathrm{mL}) \quad 2.24$

Particle size distribution by laser diffraction
D-10 $(\mu \mathrm{m})$
5
D-50 $(\mu \mathrm{m}) \quad 13$ 
Electrochemical Performance Characteristics

The FU 2651 synthetic graphite has good high-rate capability but suffers some loss of discharge capacity vs. time (Figs. 21 and 22). Also, it is significantly more expensive than all of the natural graphite materials.

ASI-\%DOD Plot

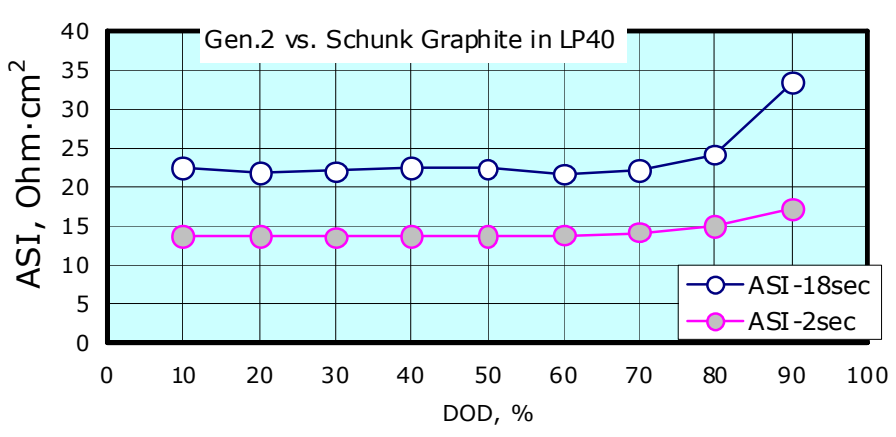

Fig. 21. HPPC Data for Schunk Graphite Technology FU 2651
Power Capability

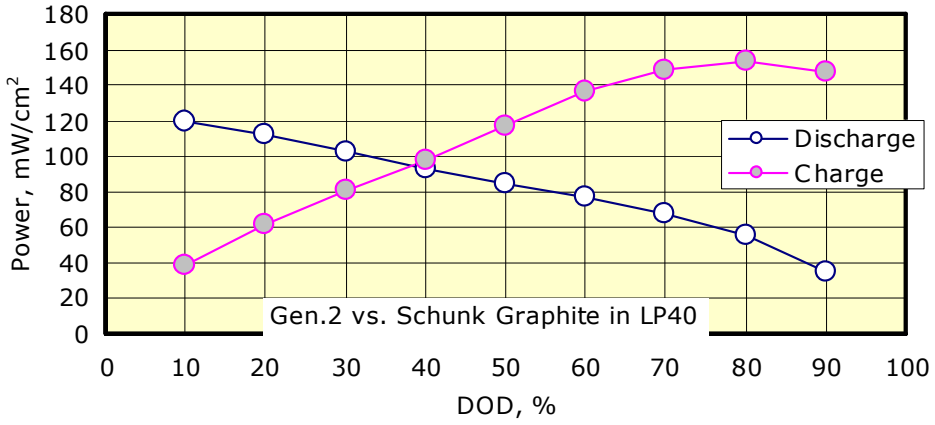

Fig. 22. Power Capability for Schunk Graphite Technology FU 2651 Calculated from HPPC Data

\section{Preliminary Safety Characteristics}

FU 2651 exhibits very good safety characteristics, as demonstrated via DSC (100\% SOC with a PC-based electrolyte) (Fig. 23).

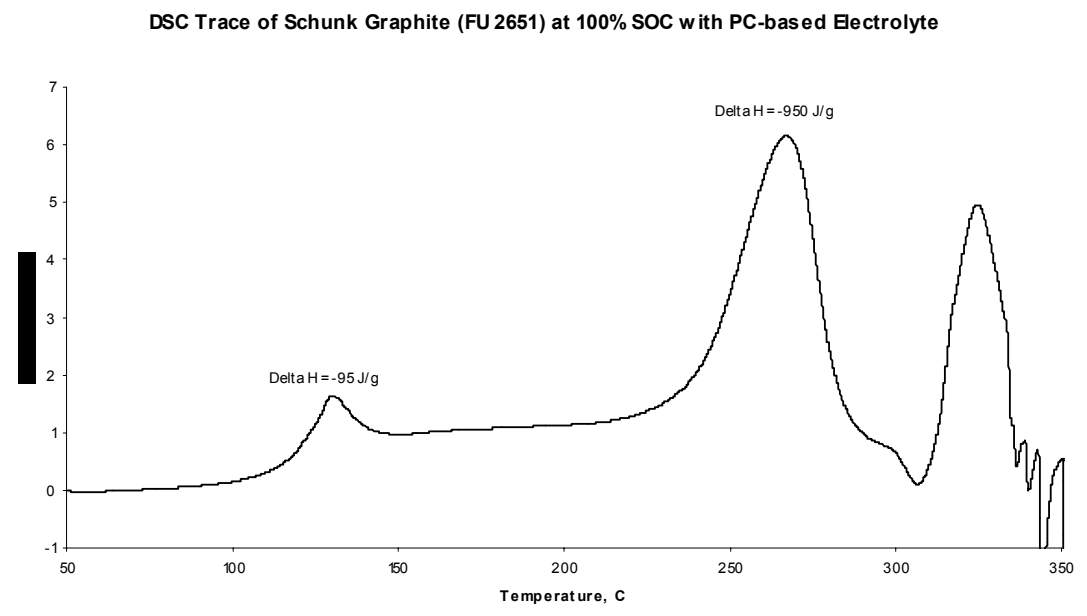

Fig. 23. DSC Data for Schunk Graphite Technology FU 2651 Graphite in PC-Based Electrolyte 


\subsection{TIMICAL}

\section{Contact Information}

Michael Spahr

TIMCAL Ltd. Graphites and Technology

CH-5643

Sins, Switzerland

Tel: $\quad 41918732010$

Fax: $\quad 41918732019$

E-mail: m.spahr@ch.timical.com

\section{$\underline{\text { Material Data }}$}

Grade: TIMREX E-SLP 50

Physical analysis

Surface area $\left(\mathrm{m}^{2} / \mathrm{g}\right) \quad$ NA

Tap density $(\mathrm{g} / \mathrm{mL}) \quad 2.6$

Particle size distribution by laser diffraction

D-10 $(\mu \mathrm{m}) \quad$ NA

D-50 $(\mu \mathrm{m}) \quad \mathrm{NA}$

D-90 $(\mu \mathrm{m}) \quad$ NA

Electrochemical Performance Characteristics

This is a very low-cost natural graphite at $\sim \$ 6 / \mathrm{kg}$. It exhibits good high-rate capabilities on HPPC tests (with Gen 2 cathode and LP40 electrolyte, Fig. 24), but it suffers a loss of discharge capacity vs. time and exhibits a steady rise in cell impedance (Fig. 25).

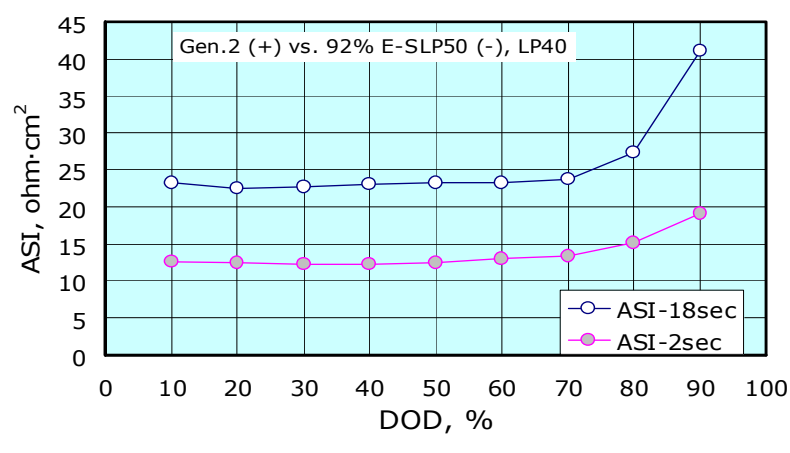

Fig. 24. HPPC Test Data for Timical E-SLP 50 Graphite

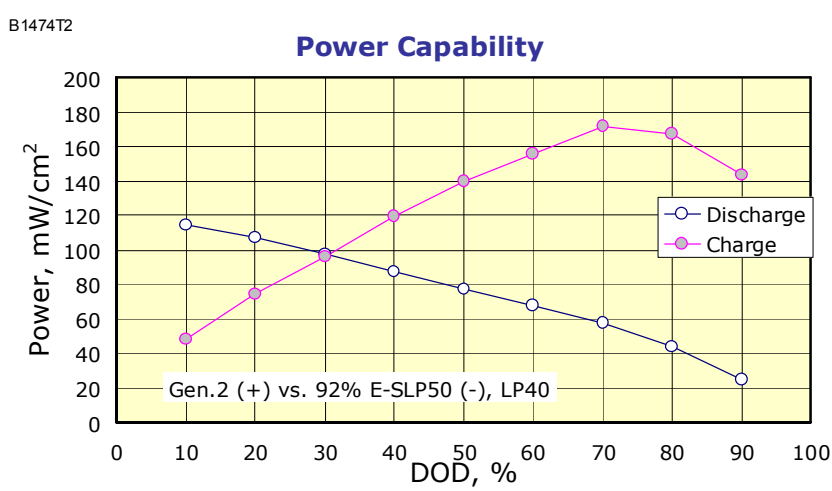

Fig. 25. Power Capability for Timical E-SLP 50 Graphite Calculated from HPPC Data 


\subsection{LITECH}

\section{$\underline{\text { Contact Information }}$}

S. Hossain

7960 South Kolb Road

Tucson, AZ 85706

Tel: (520) 574-1980

Fax: (520) 574-1983

LiTech C-C composite is produced from carbon fibers bonded with a carbon matrix.

Figure 26 shows the surface image (Fig. 26a) and cross-sectional view (Fig. 26b) of the LiTech C-C composite material. Other material data are not available.

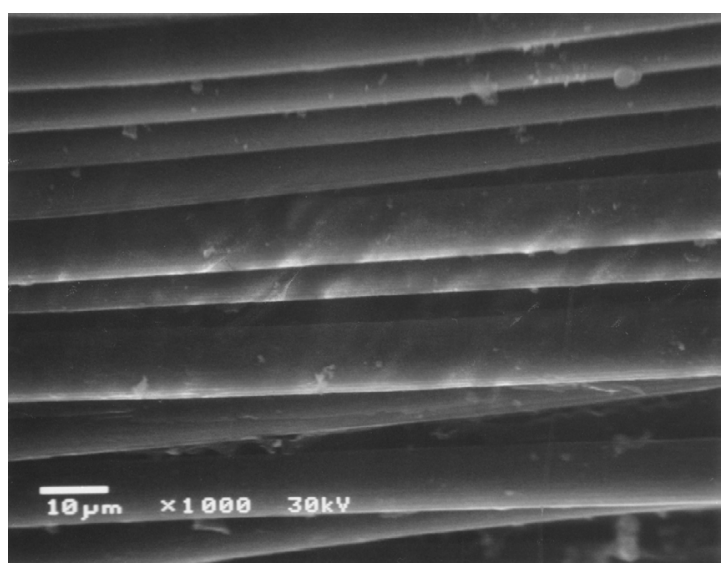

(a)

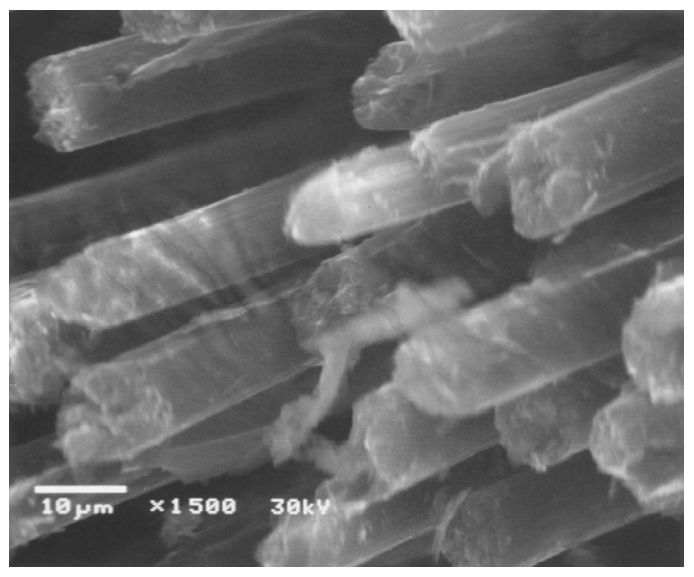

(b)

Fig. 26. SEM Images of (a) Surface and (b) Cross Section of LiTech C-C Composite

This carbon composite appears to possess several potentially attractive properties:

- Low cost due to elimination of the binder and current collector.

- Enhanced safety by eliminating reactions between binder and lithiated graphite electrode.

- Improved overdischarge tolerance by eliminating copper dissolution from the negative current collector.

\section{Cells Incorporating C-C Composite Carbon Fiber}

Argonne is collaborating with LiTech, LLC (DOE-SBIR funded) to evaluate cells based on its composite carbon fiber anode. ANL supplied its Gen 2 cathode to LiTech for cell fabrication and evaluated 10 cells with $\sim 100 \mathrm{mAh}$ capacity cells that were built by LiTech (Fig. 27). 


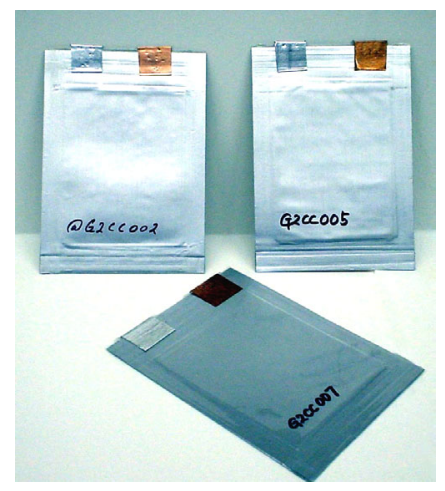

Fig. 27. Photo of LiTech-Built Cells

\section{Electrochemical Performance Characteristics}

The pouch cells employ our Gen 2 cathode material, the LiTech carbon fiber anode material (without $\mathrm{Cu}$ foil current collector), and a $1.4 \mathrm{M} \mathrm{LiPF}_{6} \mathrm{EC} / \mathrm{EMC}$ (1:3) electrolyte. During HPPC tests, these cells exhibit ASI values of $\sim 66 \mathrm{ohm}-\mathrm{cm}^{2}$ (Fig. 28) and correspondingly low power capability (Fig. 29). Similar tests in ANL lab cells-with lower contact resistance between the electrodes and the steel current collector/cell holder-show that the ASI can be reduced to $\sim 43 \mathrm{ohm}-\mathrm{cm}^{2}$ (Fig. 30) and a corresponding increase in power capabilitiy (Fig. 31). That means a significant portion of the high impedance is due to the ohmic resistance associated with the current collection system in the pouch cells. Another drawback of this electrode is the high porosity. ANL is working with LiTech LLC to obtain higher density electrodes for our high-power application.

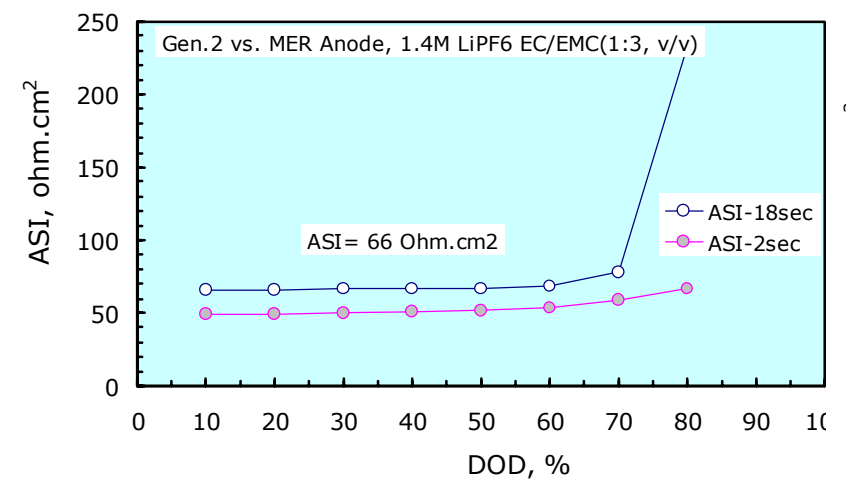

Fig. 28. ASI vs. DOD for Pouch Cells

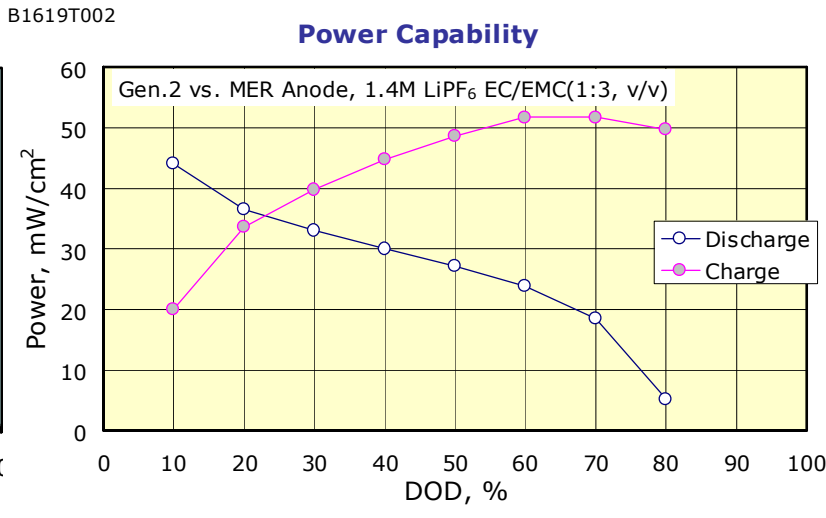

Fig. 29. Power Capability for Pouch Cells Calculated from HPPC Test Data. Pulse discharge at 10C. 


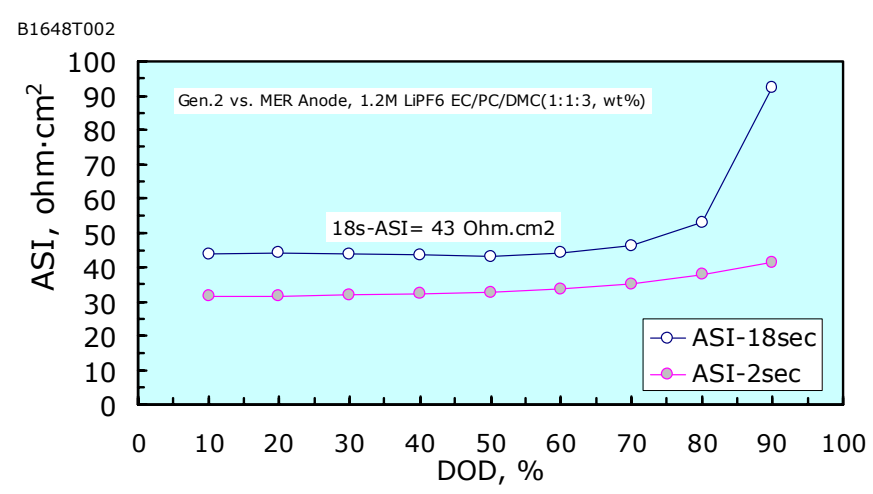

Fig. 30. ASI vs. DOD for Lab Cell Employing ANL Gen 2 Cathode, Composite Carbon Fiber Anode, and 1.2 $\mathrm{M} \mathrm{LiPF}_{6}$ in EC/PC/DMC (1:1:3) Electrolyte

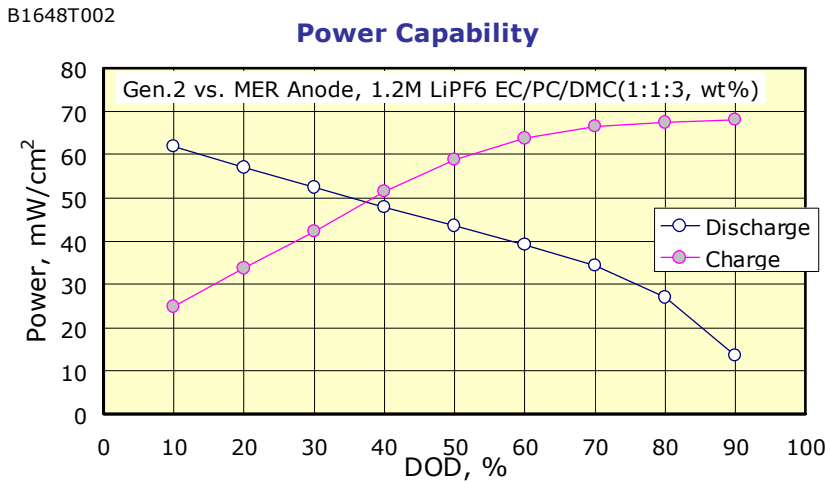

Fig. 31. Power Capability for Lab Cell Employing ANL Gen 2 Cathode, Composite Carbon Fiber Anode, and $1.2 \mathrm{M} \mathrm{LiPF}_{6}$ in $\mathrm{EC} / \mathrm{PC} / \mathrm{DMC}$ (1:1:3) Electrolyte. Pulse discharge at $10 \mathrm{C}$.

Figure 32 shows capacity fade data on two pouch cells that were cycle tested at room temperature using $1 \mathrm{C}$ rate charge/discharge cycles. One cell was subjected to extremely deep discharges (down to $1.0 \mathrm{~V}$, Fig. 32A), while the other cell was subjected to a milder overdischarge condition (discharged to $2.5 \mathrm{~V}$, Fig. 32b). Capacity retention of the cell that received the milder overdischarge was excellent. The cell subjected to the severe overdischarge on each cycle experienced significant capacity fade, but the cell was not rendered useless by this severe electrical abuse condition.

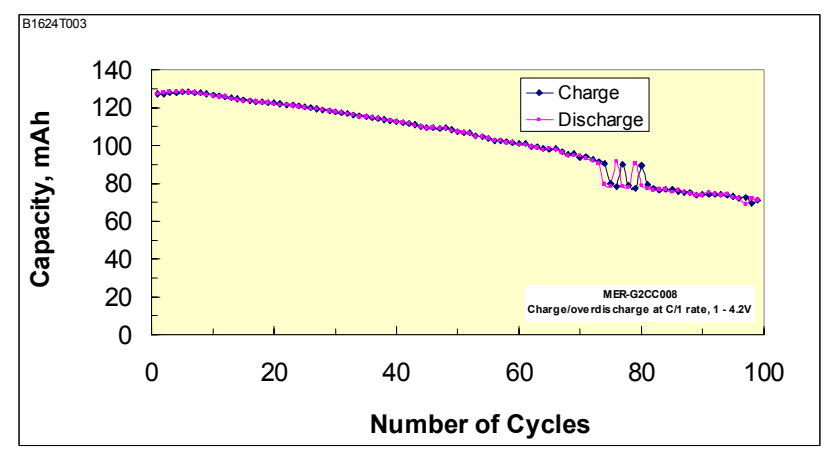

(a)

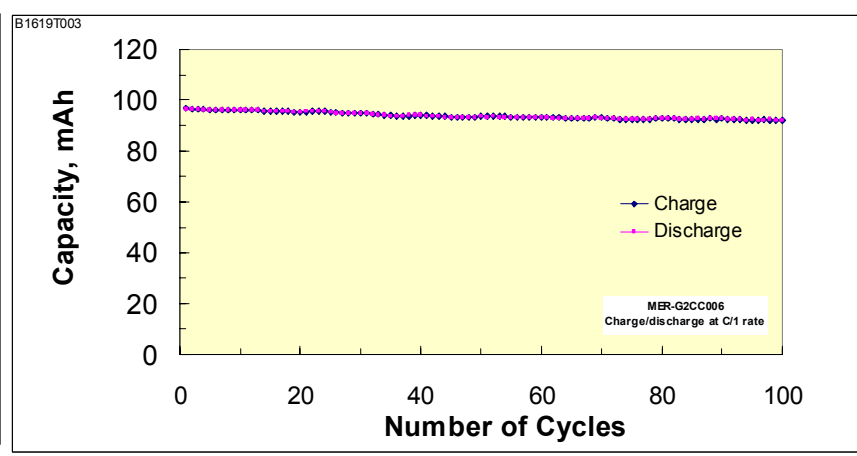

(b)

Fig. 32. Capacity Fade of Pouch Cells When Cycled between (a) 1.0 and 4.2V and (b) 2.5 and $4.2 \mathrm{~V}$ 


\section{ADVANCED CATHODE MATERIALS}

At $\$ 20.52 / \mathrm{kg}$, the $\mathrm{LiNi}_{0.8} \mathrm{Co}_{0.15} \mathrm{Al}_{0.05} \mathrm{O}_{2}$ cathode active material is the single largest material cost in our Gen 2 cell chemistry, comprising $25 \%$ of the cost of all materials present in the cell windings. Therefore, a major focus of our work has been the identification and/or development of lower cost cathode materials that possess enhanced stability, to help extend calendar life and increase the inherent safety of the cell chemistry. Table 4 provides cost information on some of the advanced cathode materials that were evaluated in this part of our materials' development and evaluation studies. In pursuing these types of materials, we are employing a strategy that involves:

- Lowering the amount of cobalt to achieve cost savings.

- Lowering the amount of nickel for the following reasons:

- Reduce cost because high nickel content increases processing difficulties and cost.

- Extend calendar life due to a lower tetravalent nickel content during operation.

- Enhance safety due to decreased thermal reactivity associated with a lower concentration of tetravalent nickel.

- Increasing the amount of manganese to achieve cost savings, enhance safety, and extend calendar life.

Table 4. High-Volume Cost Projections for Selected Advanced Cathode Materials

\begin{tabular}{|l|l|c|c|}
\hline \multirow{2}{*}{ Industrial Supplier } & \multicolumn{1}{|c|}{ Cathode Material } & \multicolumn{2}{c|}{ Projected Cost* (\$/kg) } \\
\cline { 3 - 4 } & & Spray Drying & Other Processes \\
\hline Fuji Chemical** & $\mathrm{LiNi}_{0.8} \mathrm{Co}_{0.15} \mathrm{Al}_{0.05} \mathrm{O}_{2}(\mathrm{Gen} 2)$ & 20.52 & \\
& $\mathrm{LiNi}_{0.45} \mathrm{Mn}_{0.5} \mathrm{Al}_{0.05} \mathrm{O}_{2}$ & 17.62 & $17.91 \& 20.05$ \\
& $\mathrm{LiNi}_{0.2} \mathrm{Mn}_{0.8} \mathrm{O}_{2}$ & 16.23 & $15.41 \& 19.29$ \\
\hline Seimi & $\mathrm{LiN}_{1 / 3} \mathrm{Co}_{1 / 3} \mathrm{Mn}_{1 / 3} \mathrm{O}_{2}$ & & 15.00 \\
\hline OMG America & $\mathrm{LiNi}_{\mathrm{x}} \mathrm{Mn}_{1-\mathrm{x}} \mathrm{O}_{2}$ & & 13.00 \\
\hline Tosoh & $\mathrm{Li}_{1+\mathrm{x}} \mathrm{Mn}_{2-\mathrm{x}} \mathrm{O}_{4}$ spinel & & 7.40 \\
\hline
\end{tabular}

*All cost projections are based on supplying sufficient quantities to build 100,000 HEV batteries annually.

**Fuji developed its cost projections via a manufacturing cost study funded by ANL. The second and third materials were initially synthesized and evaluated by ANL.

In addition to the materials listed in Table 4, we have evaluated and continue to evaluate advanced cathode materials obtained from many other industrial suppliers. Of special note is the fact that partially stabilized $\mathrm{Li}_{1+} \mathrm{Mn}_{2-\mathrm{x}} \mathrm{O}_{4}$ spinels were obtained from a number of suppliers, in addition to Tosoh, including: JMC, Seimi, Mitsui, Mitsubishi, and Toda. follows:

The general characteristics of these advanced cathode materials can be summarized as

- $\mathrm{LiNi}_{1 / 3} \mathrm{Mn}_{1 / 3} \mathrm{Co}_{1 / 3} \mathrm{O}_{2}$ exhibits a good rate capability and capacity stability during cycling. Also, it possesses very good ASI stability during accelerated aging and very good inherent safety characteristics. 
- $\mathrm{LiNi}_{0.5-\mathrm{x}} \mathrm{Mn}_{0.5-\mathrm{x}} \mathrm{M}_{\mathrm{x}} \mathrm{O}_{2}$-type materials do not have the best rate capability, but exhibit good capacity stability during cycling and very good inherent safety characteristics.

- $\mathrm{LiMn}_{2} \mathrm{O}_{4}$ spinels exhibit excellent high-rate capabilities and inherent safety characteristics.

\subsection{ADVANCED LAYERED CATHODE MATERIALS}

\subsubsection{Seimi Chemical Co., Ltd.}

Contact Information

M. Suhara

Seimi Chemical Co., Ltd.

3-2-10, Chigasaki

Chicasaki-City

Kanagawa, 253-8585

Japan

Tel: $\quad+81-467-82-4131$

Fax: $\quad+81-467-88-1778$

E-mail: mnbsuhara@seimichemical.co.jp

Internet: www.seimichemical.co.jp

Material Data

Grade: L-333 $\left(\mathrm{LiNi}_{1 / 3} \mathrm{Co}_{1 / 3} \mathrm{Mn}_{1 / 3} \mathrm{O}_{2}\right)$

Physical analysis

Surface area $\left(\mathrm{m}^{2} / \mathrm{g}\right) \quad 0.6$

Tap density $(\mathrm{g} / \mathrm{mL}) \quad 2.2$

Press density $(\mathrm{g} / \mathrm{mL}) \quad 2.6$

Particle size distribution by laser diffraction

D-10 $(\mu \mathrm{m}) \quad 6.92$

D-50 $(\mu \mathrm{m}) \quad 10.74$

D-90 $(\mu \mathrm{m}) \quad 15.56$

Electrochemical Performance Characteristics

The Seimi L-333 material exhibits stable capacity in cells with GDR-AA-33 anodes. Figure 33 provides initial capacity fade data for cells employing two different electrolyte compositions. The cells were charged and discharged at the $1.5 \mathrm{C}$ rate between 3.0 and 4.1 volts. 


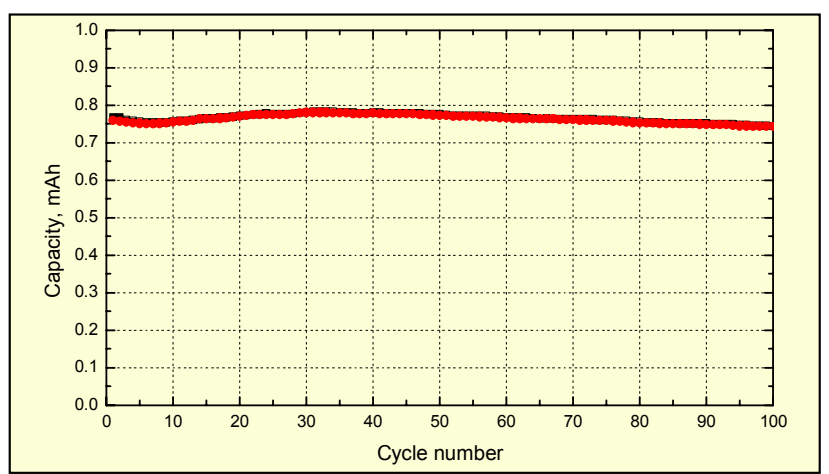

(a)

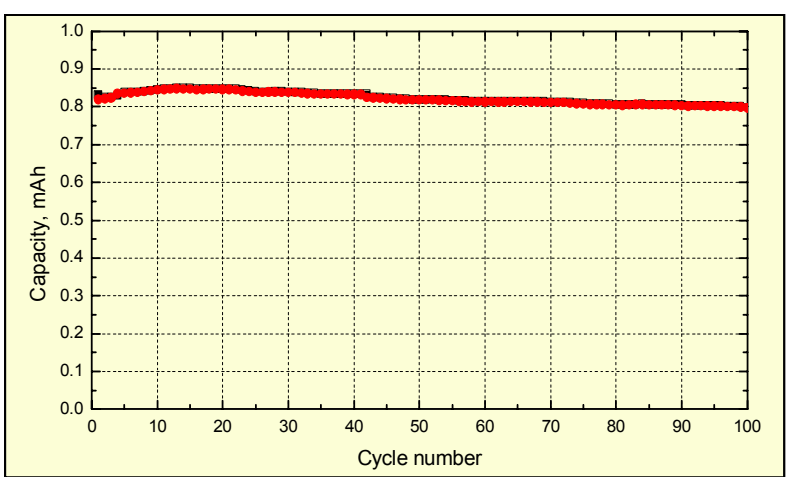

(b)

Fig. 33. Capacity Stability of Seimi Chemical L-333 Cathode Material in Cells with (a) 1.2 M LiPF 6 (EC:PC:DMC) (1:1:3) Electrolyte and (b) 1.2 M LiPF 6 (EC:PC:EMC) (1:1:3) Electrolyte

Cells employing the L-333 cathode and a GDR-AA-33 anode exhibit very good high-rate capabilities. Figure 34 provides HPPC test data at the $10 \mathrm{C}$ rate. The very low ASI values represent some of the lowest values observed by ANL. Power capability data are shown in Figure 35.

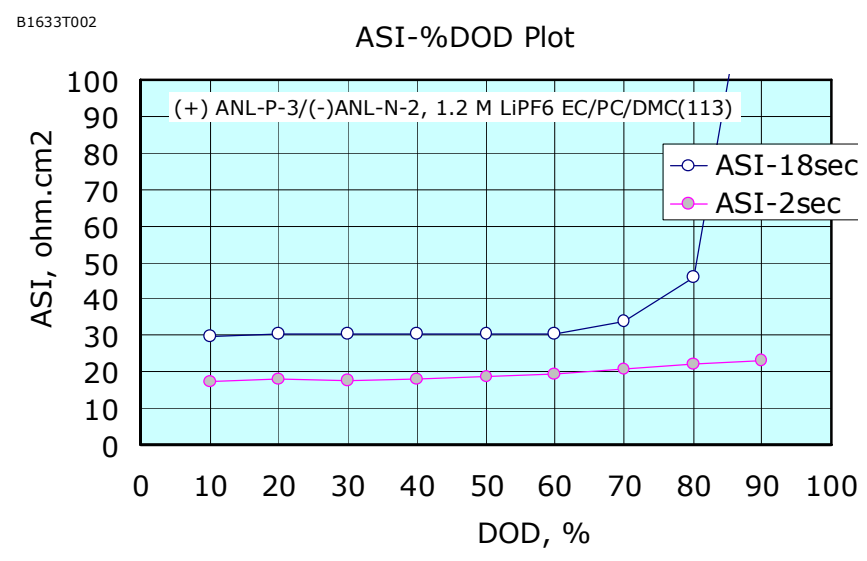

Fig. 34. 10C Rate HPPC Test Data for Seimi Chemical L-333 Cathode

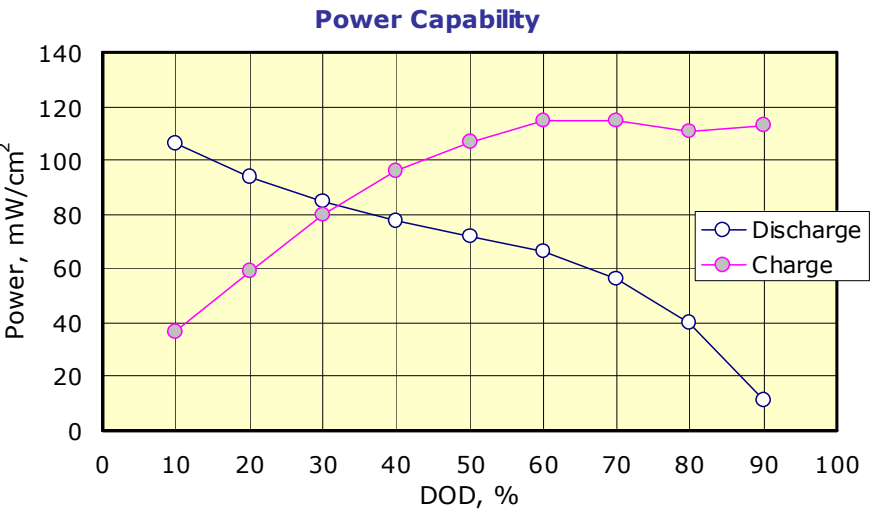

Fig. 35. Power Capability for Seimi Chemical L-333 Cathode Calculated from HPPC Data

\section{Structural Stability of $\mathrm{LiNi}_{\underline{1 / 3}} \mathrm{Co}_{\underline{1 / 3}} \underline{\mathrm{Mn}_{1 / 3}} \mathrm{O}_{\underline{2}}$}

A major reason for our prediction of extended calendar life from cells that employ the $\mathrm{Li}_{1-\mathrm{x}} \mathrm{Ni}_{1 / 3} \mathrm{Co}_{1 / 3} \mathrm{Mn}_{1 / 3} \mathrm{O}_{2}$ cathode is its structural stability during operation. We have observed some structural stress and crack formation in our Gen 1 and Gen 2 cathodes as the result of accelerated aging tests that include high-current pulse charge/discharge testing. These observed phenomena are believed to be due to nonuniform expansion and contraction within the active 
material particles associated with the high-rate lithiation and delithiation processes occurring at the particle surfaces during the high-rate discharge and charge current pulses.

Figure 36 shows there is no unit cell volume change observed in the Seimi material up to $4.6 \mathrm{~V}\left(0 \leq \mathrm{x} \leq 2 / 3\right.$ in its $\left.\mathrm{Li}_{1-\mathrm{x}} \mathrm{Ni}_{1 / 3} \mathrm{Co}_{1 / 3} \mathrm{Mn}_{1 / 3} \mathrm{O}_{2}\right)$. This indicates that we should expect to observe only minimal structural stresses develop in this material during high-current pulse and accelerated aging tests. Figure 37 provides XRD data on lithiated, delithiated, and cycled $\mathrm{Li}_{1-}$ ${ }_{x} \mathrm{Ni}_{1 / 3} \mathrm{Co}_{1 / 3} \mathrm{Mn}_{1 / 3} \mathrm{O}_{2}$ electrodes. The cycled electrode underwent 200 high-rate (5C) charge/discharge cycles. The XRD patterns were found to be virtually identical.

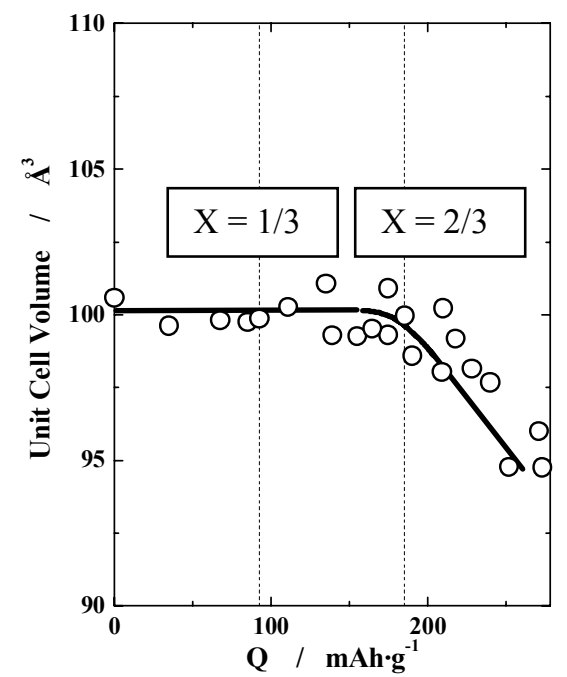

Fig. 36. Unit Cell Volume vs. SOC in Seimi Chemical Material

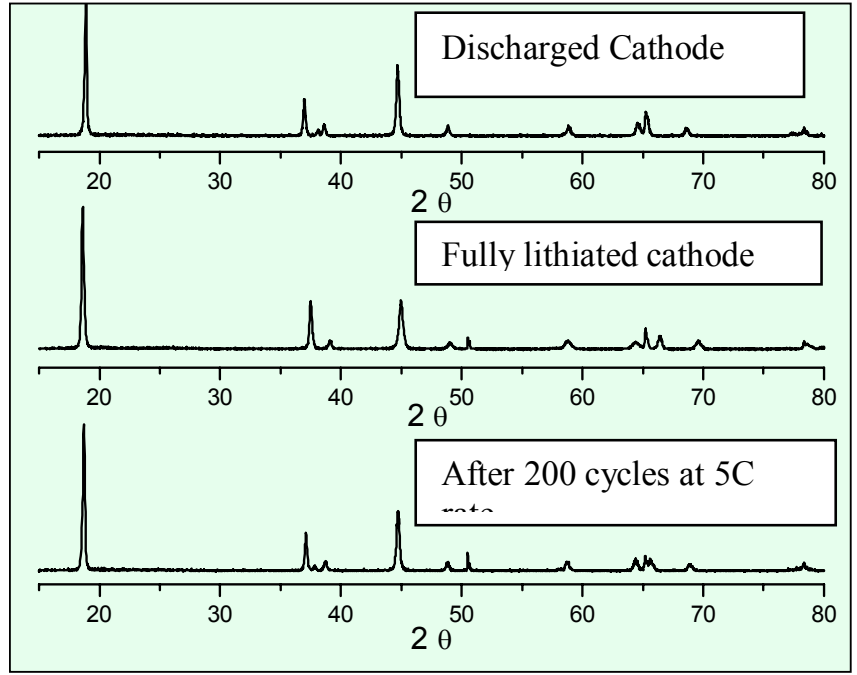

Fig. 37. XRD Patterns for New and Cycled Seimi Chemical $\mathrm{LiNi}_{1 / 3} \mathrm{Co}_{1 / 3} \mathrm{Mn}_{1 / 3} \mathrm{O}_{2}$

\section{Preliminary Safety Characteristics}

Due to the lower nickel content of the L-333 material, there will be less tetravalent nickel when charged to $4.2 \mathrm{~V}$ than we have with our Gen 1 and Gen 2 cathodes. Tetravalent nickel is extremely oxidizing and reactive with organic carbonate electrolyte solvents. Figure 38a provides DSC data on the Seimi L-333 cathode material at three different states of charge: 4.1, 4.3 , and $4.6 \mathrm{~V}$. The onset temperature is lower at higher states of charge, and the heats of reaction (in $\mathrm{J} / \mathrm{g}$ ) increase from 360 to 910 to 1200 for cathodes charged up to $4.1,4.3$ and $4.6 \mathrm{~V}$, respectively. Figure $38 \mathrm{~b}$ provides a DSC comparison of the Gen 1, Gen 2, and Seimi L-333 cathode materials, all charged to $4.3 \mathrm{~V}$. Progressing from Gen 1 through Gen 2 and on to the L333 material, the heats of reaction decrease from 2300 to 1880 to $910 \mathrm{~J} / \mathrm{g}$, and a dramatic increase in the onset temperature is observed for the L-333 cathode material. 


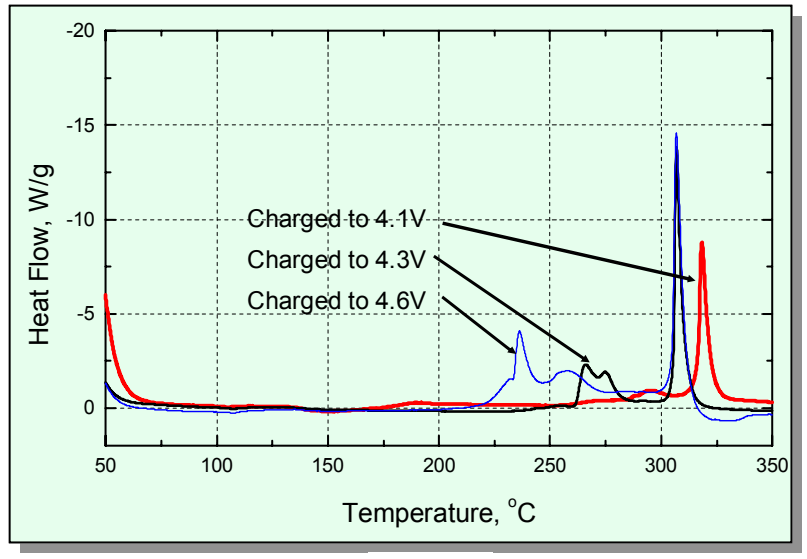

(a)

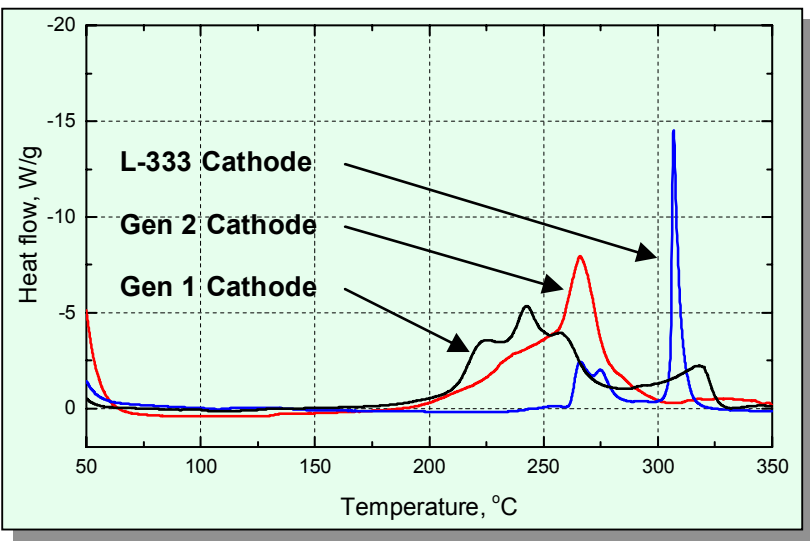

(b)

Fig. 38. Comparative DSC of (a) Seimi Chemical L-333 Cathode at Three States of Charge and (b) Gen 1, Gen 2, and L-333 Cathodes

\section{Development of Layered Lithium Nickel Manganese Oxide Materials}

ANL is working with several companies, including Tanaka, Seimi, Fuji, Mitsubishi, and Mitsui, to develop improved materials in the $\mathrm{LiNi}_{0.5-\mathrm{x}} \mathrm{Mn}_{0.5-\mathrm{y}} \mathrm{M}_{\mathrm{x}+\mathrm{y}} \mathrm{O}_{2}$ family. Figure 39 illustrates the improvements that have been achieved in lowering the impedance of cells that employ these types of cathode materials; the Co-doped material comes close to meeting the ASI target for HEV cells. Figure 40 compares the capacity density of some of these materials and shows that they possess stable capacities during our initial tests. The capacity density of this material increases as it is doped with other metals, where $\mathrm{M}^{\prime}=\mathrm{Al}, \mathrm{Co}$, or Ti.

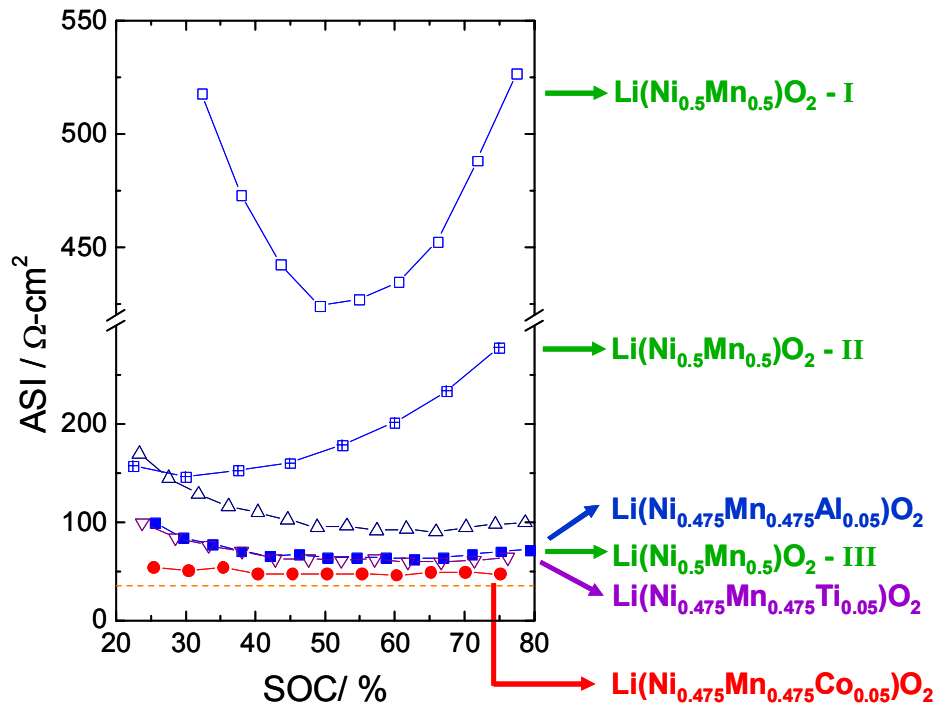

Fig. 39. ASI vs. SOC in Materials Employing $\mathrm{LiNi}_{0.5-\mathrm{x}} \mathrm{Mn}_{0.5-\mathrm{y}} \mathrm{M}_{\mathrm{x}+\mathrm{y}}^{\prime} \mathrm{O}_{2}$

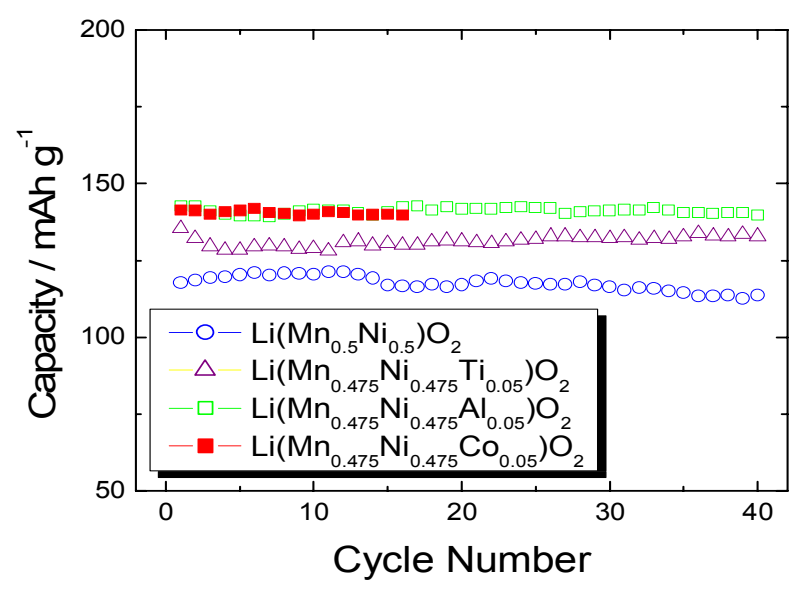

Fig. 40. Capacity Density of Selected Materials 


\subsubsection{Fuji Chemical}

\section{Contact Information}

M. Ueda

Fuji Chemical Industry Co., Ltd.

1-26, Hibiki-cho, Wakamatsu-ku, Kitakyusyu-shi

Fukuoka 808-0021, Japan

Tel: $\quad 81-93-771-7799$

Fax: $\quad 81-93-771-8090$

E-mail: ueda@fujichemical.co.jp

In the past, ANL worked with Fuji Chemical to refine the properties of its $\mathrm{LiNi}_{0.8} \mathrm{Co}_{0.15} \mathrm{Al}_{0.05} \mathrm{O}_{2}$ cathode material for the high-power $\mathrm{HEV}$ application. This refined material was used in our Gen 2 cells. We have continued to work with Fuji Chemical on the development of several advanced cathode materials with layered structures. Fuji performed detailed manufacturing cost analyses on several of the most promising advanced materials that ANL synthesized at the laboratory scale. Those results are reported in reference (1). Additionally, Fuji produced pilot-scale quantities of some of these materials for ANL to evaluate. Since these are ANL-specified materials, they do not have a Fuji product code or come with a complete set of physical properties.

\section{Electrochemical Performance Characteristics}

Figures 41 illustrates that two of these materials $\left(\mathrm{LiNi}_{0.95} \mathrm{Ti}_{0.05} \mathrm{O}_{2}\right.$ and $\mathrm{LiNi}_{0.92} \mathrm{Ti}_{0.05} \mathrm{Al}_{0.03} \mathrm{O}_{2}$ ) possess excellent capacity retention over the initial 30 cycles.

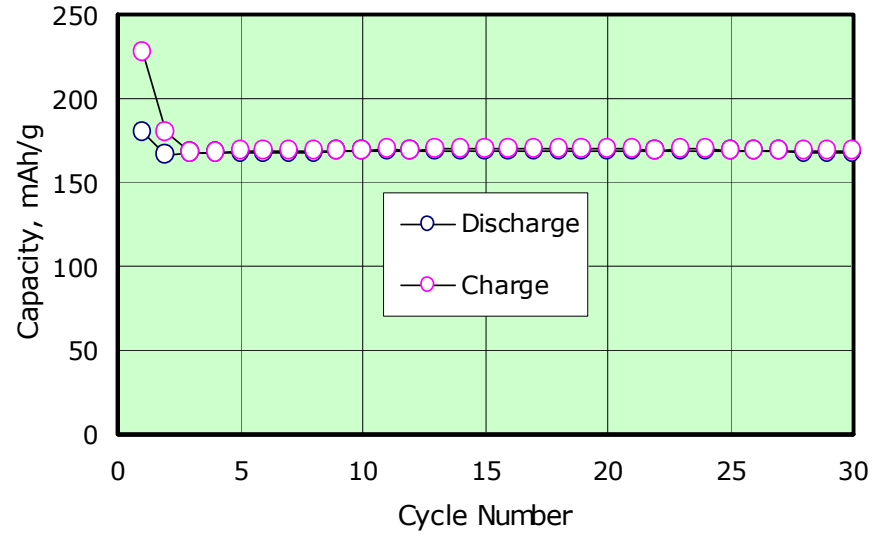

(a)

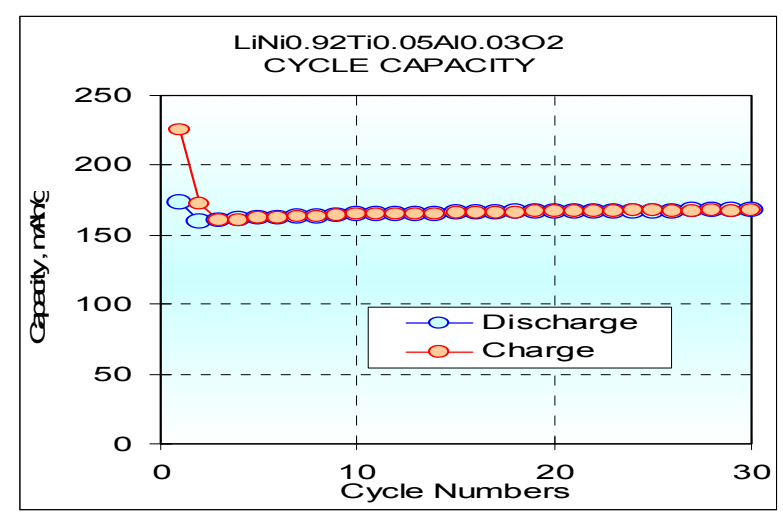

(b)

Fig. 41. Capacity Retention of Fuji Chemical (a) $\mathrm{LiNi}_{0.95} \mathrm{Ti}_{0.05} \mathrm{O}_{2}$ and (b) $\mathrm{LiNi}_{0.92} \mathrm{Ti}_{0.05} \mathrm{Al}_{0.03} \mathrm{O}_{2}$ Cathode 
These two Fuji-produced materials exhibited good high-rate capabilities on HPPC tests, as Figure 42 indicates. These materials were evaluated in cells that employed our Gen 1 anode and our Gen 1 electrolyte.

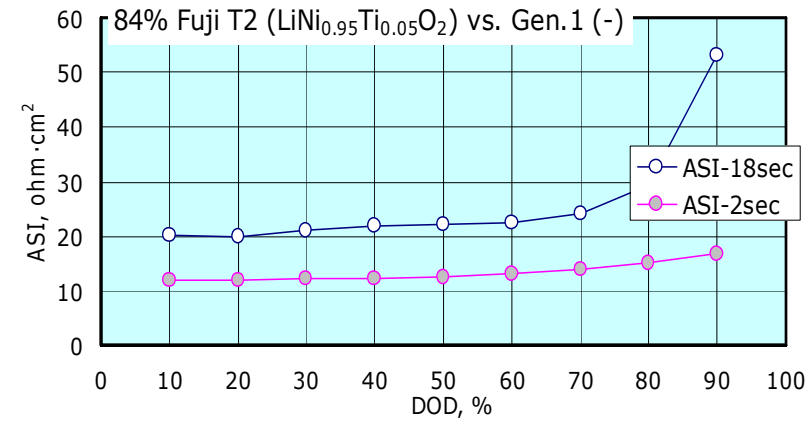

(a)

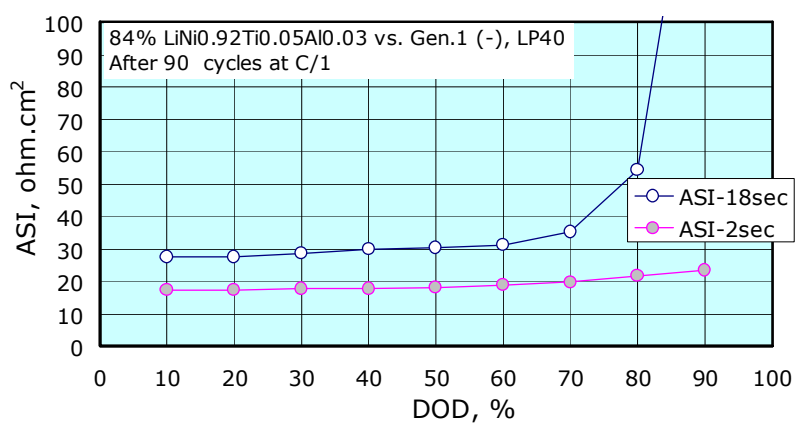

(b)

Fig. 42. HPPC Data for Fuji Chemical (a) $\mathrm{LiNi}_{0.95} \mathrm{Ti}_{0.05} \mathrm{O}_{2}$ and (b) $\mathrm{LiNi}_{0.92} \mathrm{Ti}_{0.05} \mathrm{Al}_{0.03} \mathrm{O}_{2}$ Cathode Material

\subsection{ADVANCED LiMn ${ }_{2} \mathrm{O}_{4}$ SPINEL CATHODE MATERIALS}

ANL has interacted closely with Tosoh, JMC, Seimi, Mitsui, Mitsubishi, and Toda to develop and acquire partially stabilized $\mathrm{LiMn}_{2} \mathrm{O}_{4}$ spinel cathode materials having appropriate morphologies, for evaluation by ANL. Various approaches have been utilized to help stabilize the spinel from $\mathrm{Mn}^{2+}$ dissolution in the electrolyte. If one eliminates $\mathrm{Mn}^{2+}$ dissolution, this would be an ideal cathode for high-power HEV applications, for the following reasons:

- It is much lower in cost than any of the layered cathode materials.

- It possesses better high-rate capabilities than layered materials, due to its 3-dimensional structure, and this allows a reduction in cell capacity and a corresponding further reduction in material costs.

- $\mathrm{Mn}^{4+}$ is much less oxidizing than $\mathrm{Ni}^{4+}$, thereby resulting in less reactivity with the organic carbonate electrolyte solvents (translating to enhanced inherent safety and possibly extended calendar life).

- Also, the use of smaller capacity cells will further enhance the inherent safety of the battery.

In addition to evaluating the partially stabilized spinels, ANL has been pursuing the development of a more compatible electrolyte system for use with spinel. Standard electrolytes employ $\mathrm{LiPF}_{6}$ salt, which reacts with trace amounts of water or alcohol in the organic solvents to form HF. In turn, the $\mathrm{HF}$ will readily attack and dissolve $\mathrm{Mn}^{2+}$. Therefore, we have been investigating electrolyte systems that employ alternative salts. The most promising of these is lithium bis(oxalate)borate salt, denoted LiBOB. In this part of the report, we examine the spinel cathode material in combination with changing to a LiBOB salt-based electrolyte system. 


\subsubsection{Tosoh}

\section{$\underline{\text { Contact Information }}$}

Masaki Okada

Tosoh Corporation

Nanyo Research Laboratory

4560, Kaisei-cho, Shin-nanyo,

Yamaguchi 746-8501 Japan

Tel: $\quad 81-834-63-9937$

Fax: 81-834-63-9923

E-mail: okada_m@tosoh.co.jp

$\underline{\text { Material data }}$

Al-doped spinel

Physical analysis

Surface area $\left(\mathrm{m}^{2} / \mathrm{g}\right) \quad 0.56$

Tap density $(\mathrm{g} / \mathrm{mL}) \quad 1.82$

Particle size distribution by laser diffraction

D-10 $(\mu \mathrm{m}) \quad 7.42$

D-50 $(\mu \mathrm{m}) \quad 17.78$

D-90 $(\mu \mathrm{m}) \quad 30.08$

$\mathrm{Li}_{1.06} \mathrm{Mn}_{1.94} \mathrm{O}_{4}$

Physical analysis

Surface area $\left(\mathrm{m}^{2} / \mathrm{g}\right) \quad 0.53$

Tap density $(\mathrm{g} / \mathrm{mL}) \quad 1.82$

Bulk density $(\mathrm{g} / \mathrm{mL}) \quad 1.10$

$\mathrm{Li} / \mathrm{Mn}=\quad 0.586$

Particle size distribution by laser diffraction

D-10 $(\mu \mathrm{m}) \quad 8.36$

D-50 $(\mu \mathrm{m}) \quad 16.85$

D-90 $(\mu \mathrm{m}) \quad 26.68$

Electrochemical Performance Characteristics

The Tosoh spinels $\left(\mathrm{Li}_{1.06} \mathrm{Mn}_{1.94} \mathrm{O}_{4}\right.$ and Al-doped spinel) exhibit stable capacities in cells that employ metallic lithium anodes. Figure 43 shows the capacity stability of Tosoh's $\mathrm{Li}_{1.06} \mathrm{Mn}_{1.94} \mathrm{O}_{4}$ cathode material during cycle testing at $50^{\circ} \mathrm{C}$. 


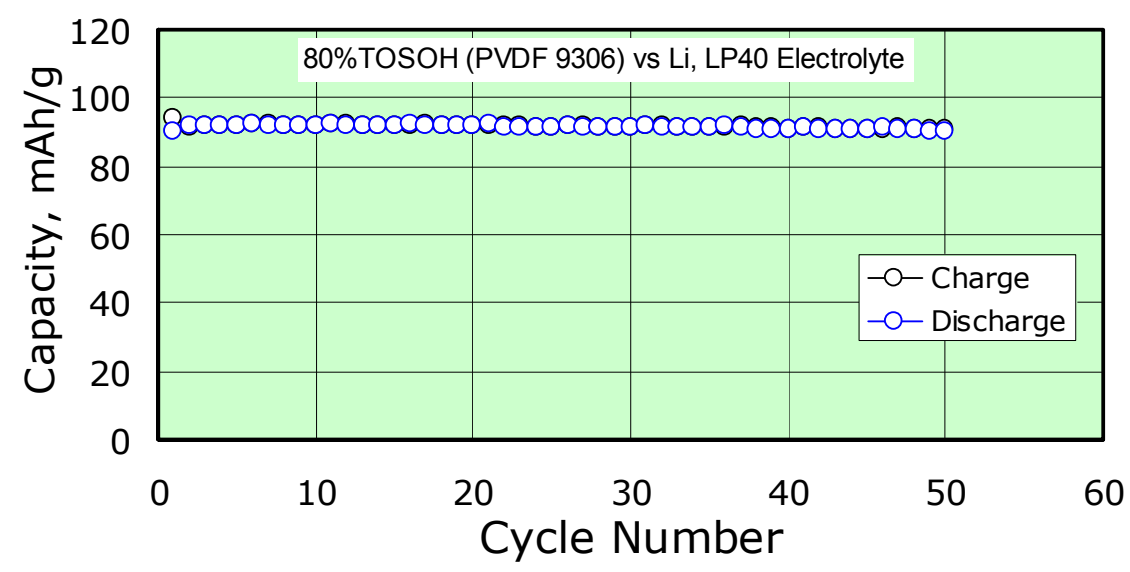

Fig. 43. Capacity Stability of Tosoh $\mathrm{Li}_{1.06} \mathrm{Mn}_{1.94} \mathrm{O}_{4}$ Material in Cell with Metallic Lithium Anode

Although the Al-doped material has relatively low capacity density, it exhibits good capacity retention and excellent ASI retention in cells that employ graphite anodes and an electrolyte that uses $\mathrm{LiPF}_{6}$ salt when operated at room temperature. Figure 44 shows the capacity stability, while Figure 45 shows the ASI retention of a cell that was cycled for more than 60 full charge/discharge cycles at room temperature.

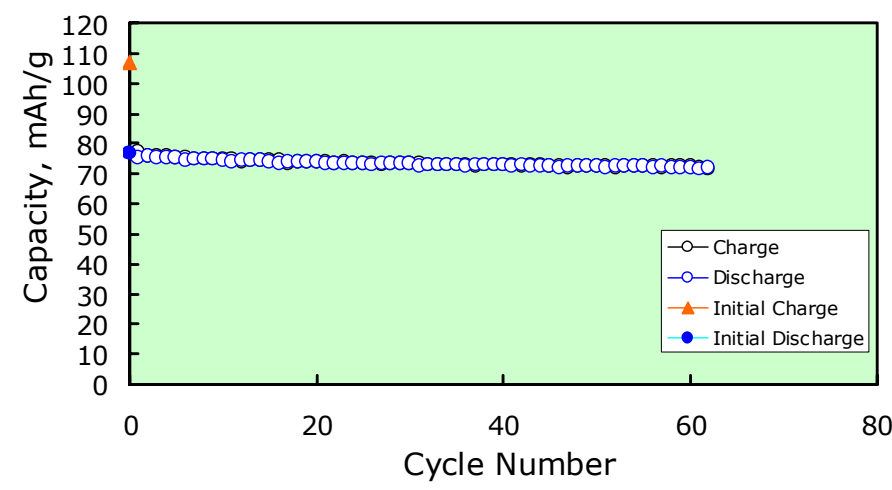

Fig. 44. Capacity Stability for Tosoh Al-Doped Spinel Cell

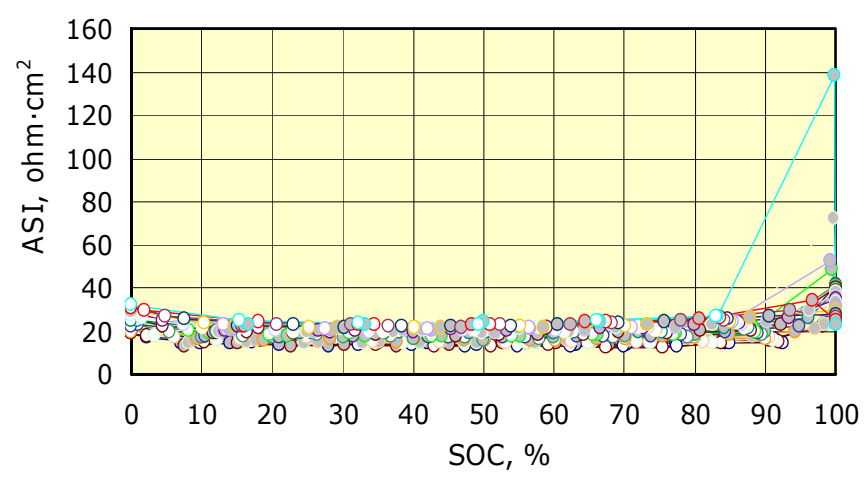

Fig. 45. ASI retention for Tosoh Al-Doped Spinel Cell

\section{Preliminary Safety Characteristics}

A dramatic improvement in safety is observed when comparing DSC data for a $\mathrm{LiNi}_{0.8} \mathrm{Co}_{0.2} \mathrm{O}_{2}$ cathode (Fig. 46a) to that for a Tosoh spinel (Fig. 46b). The spinel system has the added advantage of using a less reactive salt (LiBOB) in the same solvent system. The onset temperature is increased by $50-60^{\circ} \mathrm{C}$, and the heat of reaction is reduced from $3900 \mathrm{~J} / \mathrm{g}$ to $60 \mathrm{~J} / \mathrm{g}$. 


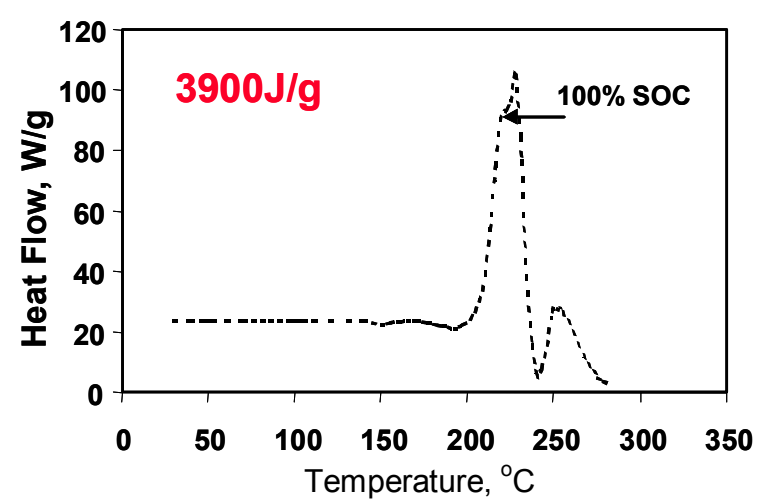

(a)

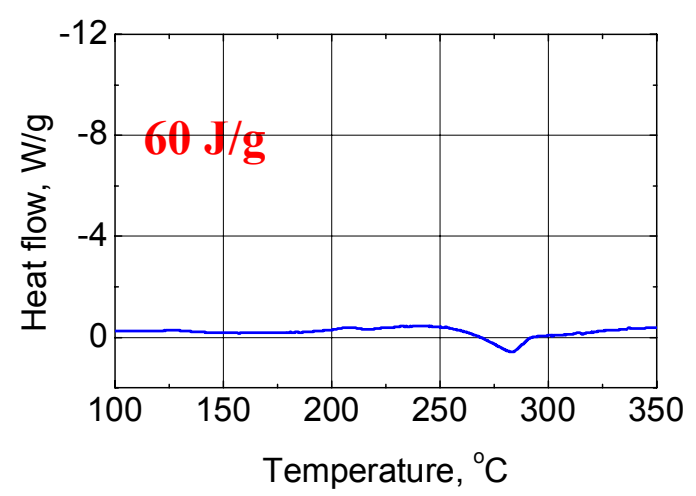

(b)

Fig. 46. DSC for (a) $\mathrm{LiNi}_{0.8} \mathrm{Co}_{0.2} \mathrm{O}_{2}$ in $\mathrm{LiPF}_{6} \mathrm{EC}$ :DEC (1:1) Electrolyte and (b) Tosoh Spinel in LiBOB EC:DEC (1:1) Electrolyte

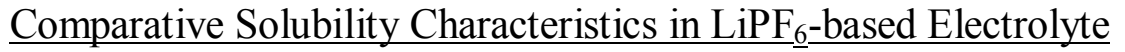

The Tosoh spinel is stabilized in a manner that suppresses the solubility of $\mathrm{Mn}^{2+}$. Figure 47 shows data obtained from $50^{\circ} \mathrm{C}$ leach tests using the spinel powders and LP40 electrolyte $\left(1 \mathrm{M} \mathrm{LiPF}_{6}\right.$ in EC:DEC [1:1]). The results show that the amount of $\mathrm{Mn}^{2+}$ leached from the Tosoh spinel is negligible compared with the amount of $\mathrm{Mn}^{2+}$ that is leached from a standard spinel over a three-week period.

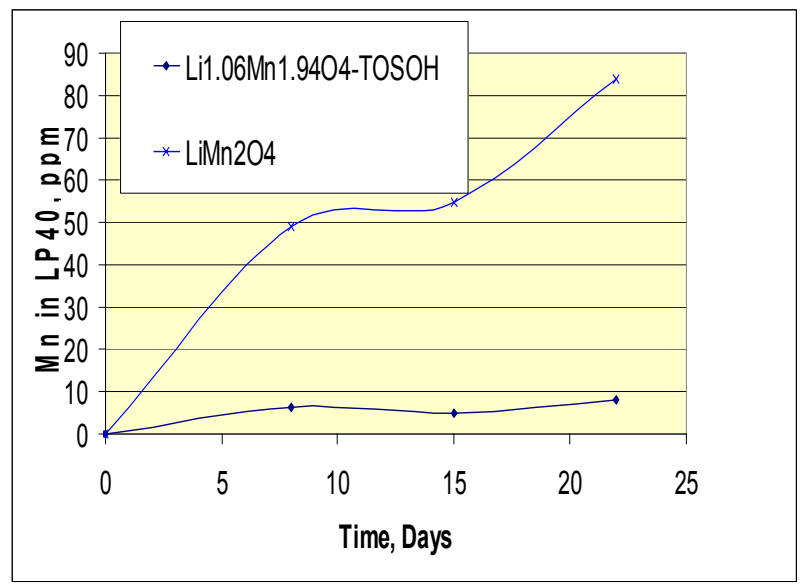

Fig. 47. Mn Concentration in LP40 Electrolyte Resulting from Three-Week Leach at $50^{\circ} \mathrm{C}$

Enhanced Characteristics Related to Use of a LiBOB Electrolyte

As indicated previously, we have been pursuing the identification and development of electrolytes that employ alternative salts to $\mathrm{LiPF}_{6}$. The most promising salt to date is lithium bis(oxalate)borate (LiBOB), which has numerous advantages over LiPF. The chemical structure of this salt is shown in Figure 48. 


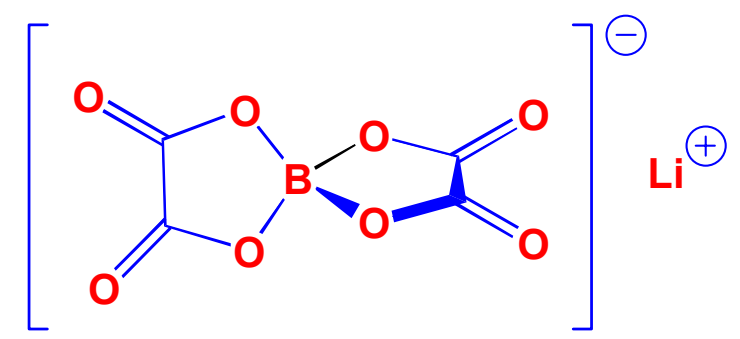

Fig. 48. Chemical Structure of LiBOB Salt

\section{Dissolution of $\mathrm{Mn}^{2+}$}

ANL investigated the effect of using LiBOB electrolyte on the dissolution of $\mathrm{Mn}^{2+}$ from stabilized and conventional spinel powders during controlled leaching tests at $50^{\circ} \mathrm{C}$. Figure 49 compares the quantities of $\mathrm{Mn}^{2+}$ dissolved in the electrolyte when using a $\mathrm{LiPF}_{6}$ electrolyte (Fig. 49a) and a LiBOB electrolyte (Fig. 49b). When using the LiBOB electrolyte, the quantity of dissolved $\mathrm{Mn}^{2+}$ is at the lower detection limit for the ICP unit, even when using the conventional spinel.

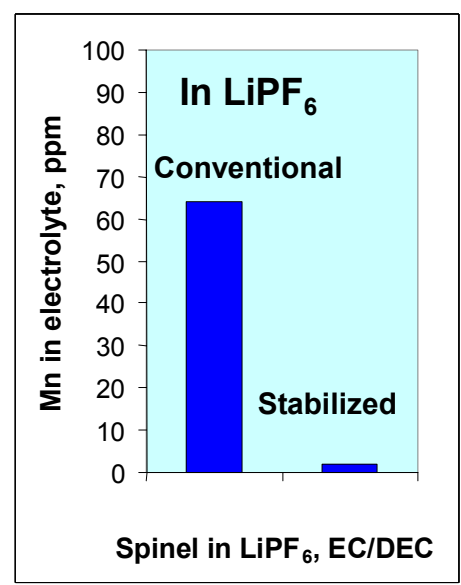

(a)

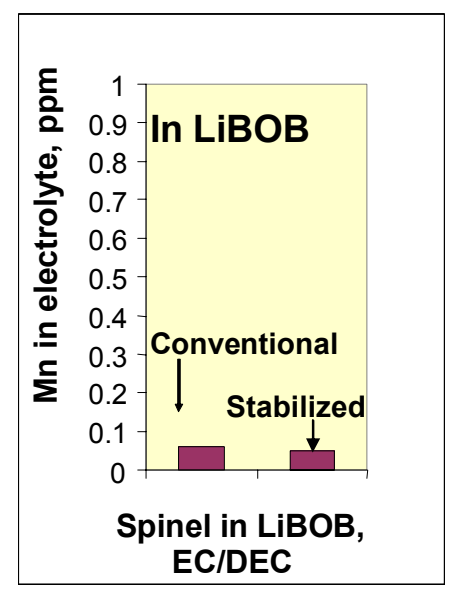

(b)

Fig. 49. $\mathrm{Mn}^{2+}$ Dissolution in Electrolyte Using (a) $\mathrm{LiPF}_{6}$ Electrolyte and (b) LiBOB Electrolyte

\section{Safety}

ANL investigated the effect of using LiBOB-based electrolytes on the exothermic reactions that occur between the electrolyte and a charged spinel cathode during DSC experiments. Figure 50 compares DSC data on the Tosoh spinel in the presence of two different electrolytes. Negligible heat is generated in reactions of the Tosoh $\left(\mathrm{Li}_{1.06} \mathrm{Mn}_{1.94} \mathrm{O}_{4}\right)$ spinel with LiBOB electrolyte, as shown in Figure 50a. Figure 50b shows that significantly more heat is generated with the same cathode with a $\mathrm{LiPF}_{6}$-based electrolyte. 
1.0 M LiBOB/EC:DEC (1:1)

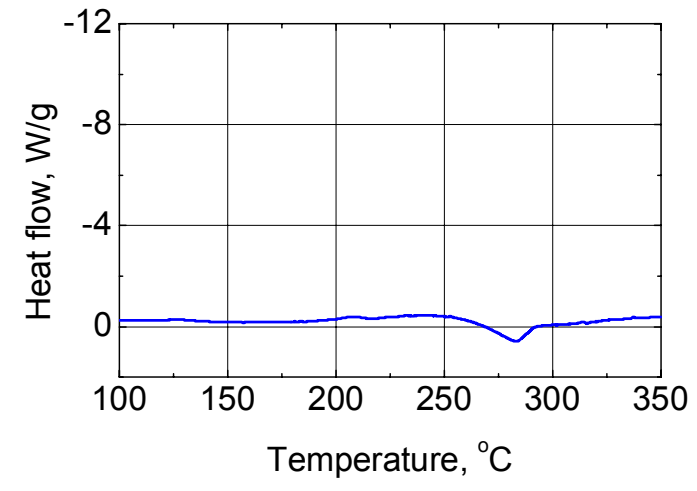

(a)
1.0 $\mathrm{M} \mathrm{LiPF}_{6} / \mathrm{EC}: \mathrm{DEC}(1: 1)$

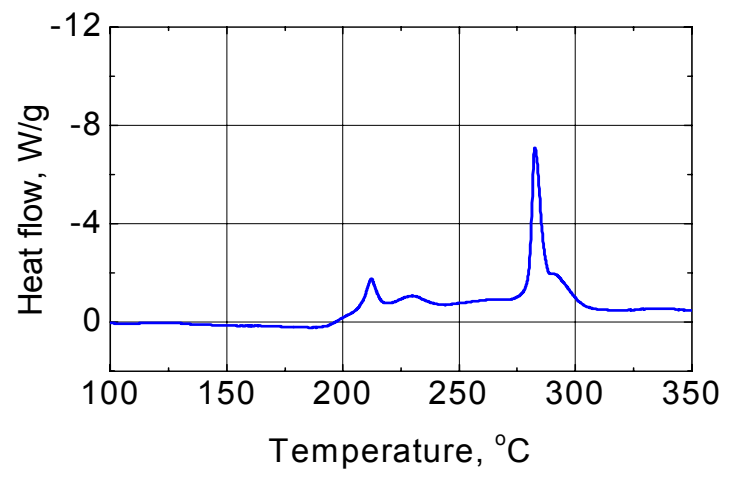

(b)

Fig. 50. DSC for Spinel with (a) LiBOB Electrolyte and (b) $\mathrm{LiPF}_{6}$ Electrolyte

\section{Electrochemical Performance}

ANL is investigating the performance of LiBOB electrolytes for possible use in highpower applications. Figure 51a shows that unacceptably high ASI values were obtained with a standard EC/DEC solvent system. However, very good ASI values were obtained using a nonconventional solvent system supplied by the salt manufacturer (Chemetall, Fig. 51b). This electrolyte is denoted the Chemetall M8 electrolyte. More work is needed to develop an optimal solvent system for this salt.

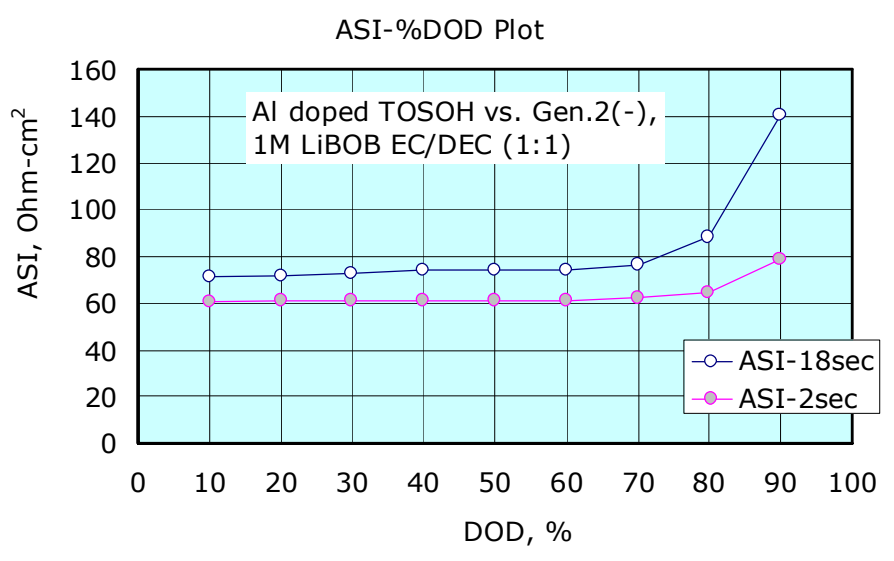

(a)

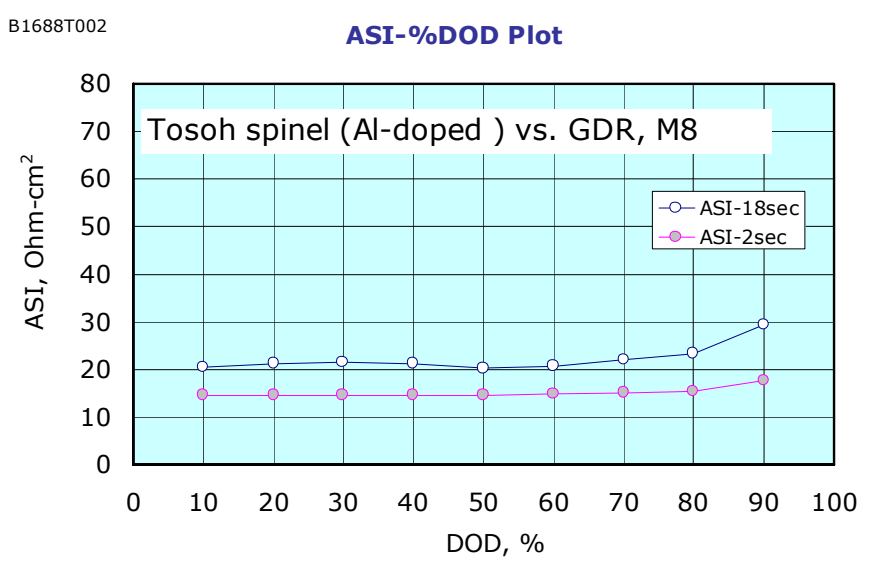

(b)

Fig. 51. HPPC Test with (a) Conventional Solvents (with LiBOB) and (b) Chemetall M8

Numerous investigators have shown that very low levels of $\mathrm{Mn}^{2+}$ dissolved in the electrolyte can cause a dramatic reduction in the capacity of cells that employ graphite anodes. Based on the reduced solubility of $\mathrm{Mn}^{2+}$ in the LiBOB electrolytes, ANL investigated capacity fade in cells that use Tosoh's Al-doped spinel, with either LiBOB electrolyte or a standard $\mathrm{LiPF}_{6}$ electrolyte. The use of LiBOB (Fig. 52a) and $\mathrm{LiPF}_{6}$ (Fig. 52b) based electrolytes are compared 
below. Both cells were cycled at the $0.7 \mathrm{C}$ rate and at $50^{\circ} \mathrm{C}$. The significant improvement in fade can be attributed to the significantly reduced manganese dissolution into the $\mathrm{LiBOB}$ electrolyte.

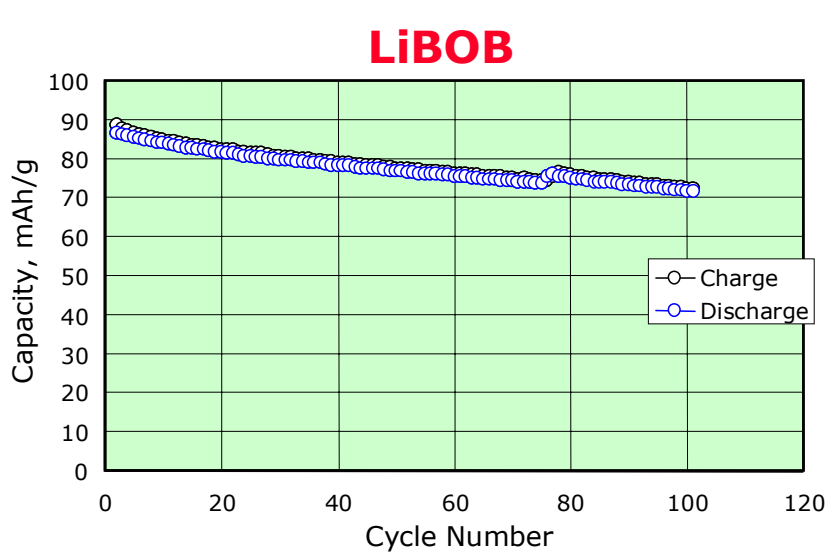

(a)

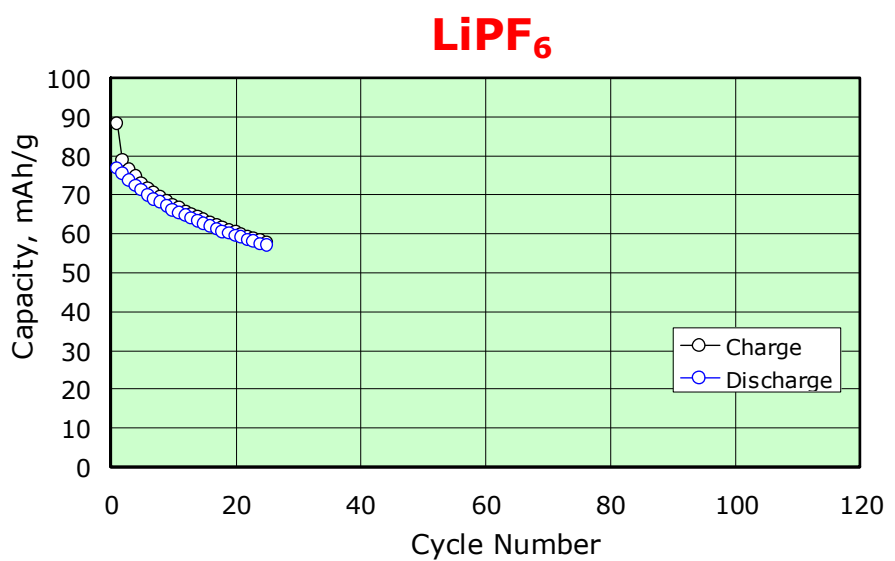

(b)

Fig. 52. Capacity Fade in Cells Employing Tosoh Al-Doped Spinel with (a) LiBOB Electrolyte and with (b) $\mathrm{LiPF}_{6}$ Electrolyte

A significantly reduced level of capacity fade is observed in cells that employ the LiBOB electrolyte. These cells incorporate the Tosoh Al-doped stabilized spinel, an optimized graphite (GDR-AA-3), and two different electrolytes.

\subsubsection{Japan Metals \& Chemicals}

\section{Contact Information}

Eiichi Shimizu

Japan Metals \& Chemicals Co., Ltd.

Advanced Materials Dept.

JMC Building

No. 8-4 Koami-cho, Nihonbashi

Chuo-ku, Tokyo 103-8531 Japan

Tel: $\quad 81-3-3667-2502$

Fax: 81-3-3667-3193

E-mail: shimzue@jmc.co.jp

Material data

Grade: LM-123

Physical analysis

Surface area $\left(\mathrm{m}^{2} / \mathrm{g}\right) \quad 1.13$

Tap density $(\mathrm{g} / \mathrm{mL}) \quad 1.98$ 
Particle size distribution by laser diffraction
D-10 $(\mu \mathrm{m}) \quad 3.3$
D-50 $(\mu \mathrm{m}) \quad 10.7$
D-90 $(\mu \mathrm{m}) \quad 20.5$

Electrochemical Performance Characteristics

Japan Metals \& Chemicals Company produces a coated spinel, grade LM-123. This material performs in a manner similar to the Tosoh stabilized spinel. It exhibits a reduced rate of capacity fade and excellent impedance stability during preliminary accelerated aging tests (Figs. 53 and 54).

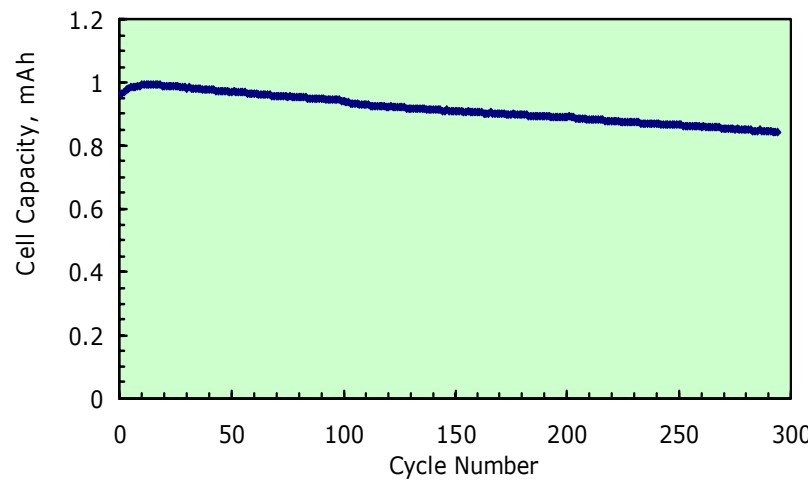

Fig. 53. Capacity Fade in Japan Metals and Chemicals LM-123 Spinel

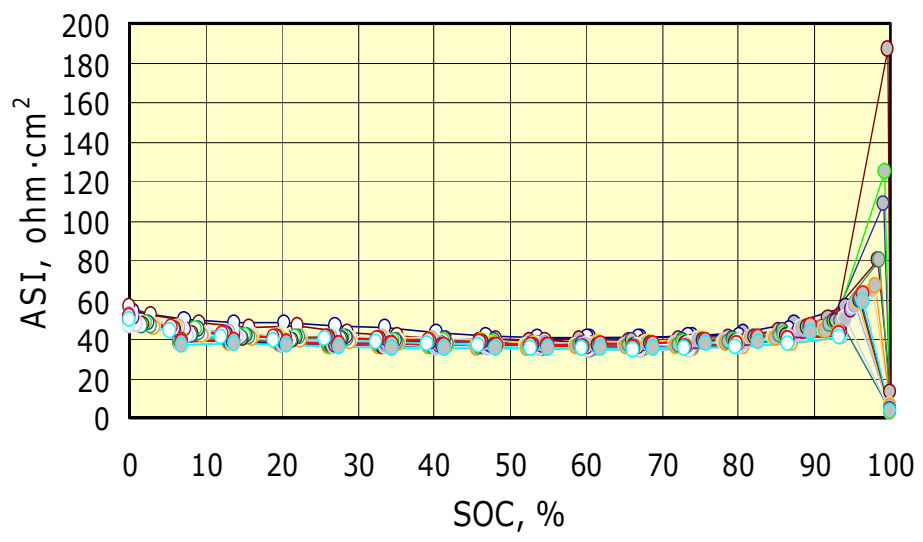

Fig. 54. ASI Stability Data for Japan Metals and Chemicals LM-123 Spinel

\subsubsection{Seimi Chemical}

\section{Contact Information}

M. Suhara

Seimi Chemical Co., Ltd.

3-2-10, Chigasaki

Chicasaki-City

Kanagawa, 253-8585

Japan

Tel: $\quad+81-467-82-4131$

Fax: $\quad+81-467-88-1778$

E-mail: mnbsuhara@seimichemical.co.jp

Internet: www.seimichemical.co.jp

Seimi Chemical Company produces a spinel, which they denote as grade M-216 spinel. This material exhibits acceptable high-power performance. ASI vs. DOD data on this material in a cell that employs our Gen 1 anode and $1 \mathrm{M} \mathrm{LiPF}_{6}$-in-EC:DEC (1:1) electrolyte are provided in Figure 55. 


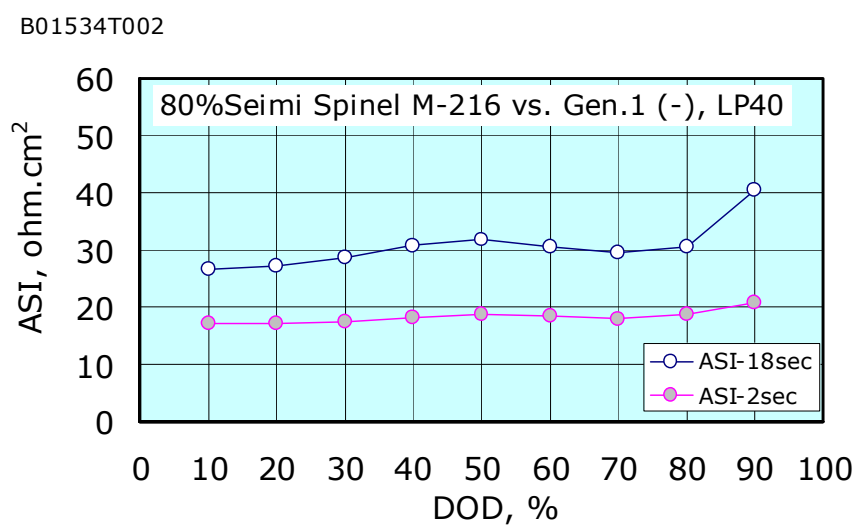

Fig. 55. HPPC Test for Seimi Chemical M-216 Spinel

\subsection{OTHER ADVANCED CATHODE MATERIALS}

ANL is in the process of evaluating a large number of other advanced cathode materials. Included in these are both advanced layered and 3-D spinel materials.

- The layered materials are from Tanaka, Seimi, Fuji, Mitsubishi, and Mitsui.

- The 3-D spinel materials are from Mitsubishi, Seimi, Tosoh, JMC, Mitsui, and Toda. 


\section{NOVEL SEPARATOR MATERIALS}

In our Gen 2 cell chemistry, the cost of the separator is a significant part $(22 \%)$ of the total material cost. The FreedomCAR Electrochemical Energy Storage Technical Team has established contracts with several industrial firms to develop lower cost separators. The FreedomCAR cost target is $\$ 1.00 / \mathrm{m}^{2}$. We are hoping to gain access to these materials for evaluation purposes. During the last year, we did obtain samples of a novel new separator material that was not developed with funding from the FreedomCAR Partnership. Information on this material is provided below.

\subsection{DEGUSSA}

\section{Contact Information}

V. Hennige

Degussa

Paul-Baumann-Strasse 1

Gebaude 1266/14

45764 Marl

Germany

Tel: $\quad+49-2365-49-4267$

Fax: $\quad+49-23$ 65-49-80 4267

E-mail: Volker.hennige@degussa.com

Internet: www.creavis.de

The Degussa separator is a low-cost ceramic separator that uses a new approach involving a non-woven film support (less than $\$ 0.30 / \mathrm{m}^{2}$ ) onto which they coat nano-particle ceramics, to increase surface wetability. The projected cost on scale up is $\$ 1.00-1.50 / \mathrm{m}^{2}$ (as compared with current costs in the $\$ 2.50-3.00$ per $\mathrm{m}^{2}$ range). Figure 56 provides a depiction of the SEPARION separator. The inorganic coating is applied as a suspension onto a polymeric non-woven support.

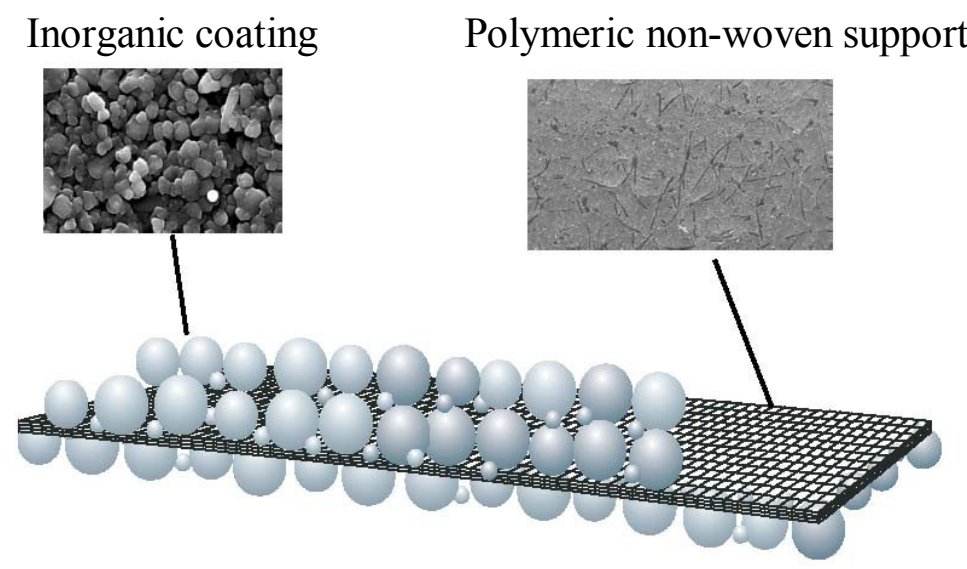

Fig. 56. Degussa SEPARION Separator 
Different pore sizes can be obtained by adjusting the choice of inorganic material. Due to the hydrophilic properties of the inorganic layer, very good wetability is obtained. The resulting high-porosity and thin separators exhibit low ionic resistance for an electrolyte-impregnated separator.

Figure 57 illustrates the continuous coating process that is used by Degussa to produce these separators. The ceramic suspension is coated onto the support, dried, and then hardened. This process results in a stable separator than remains flexible.
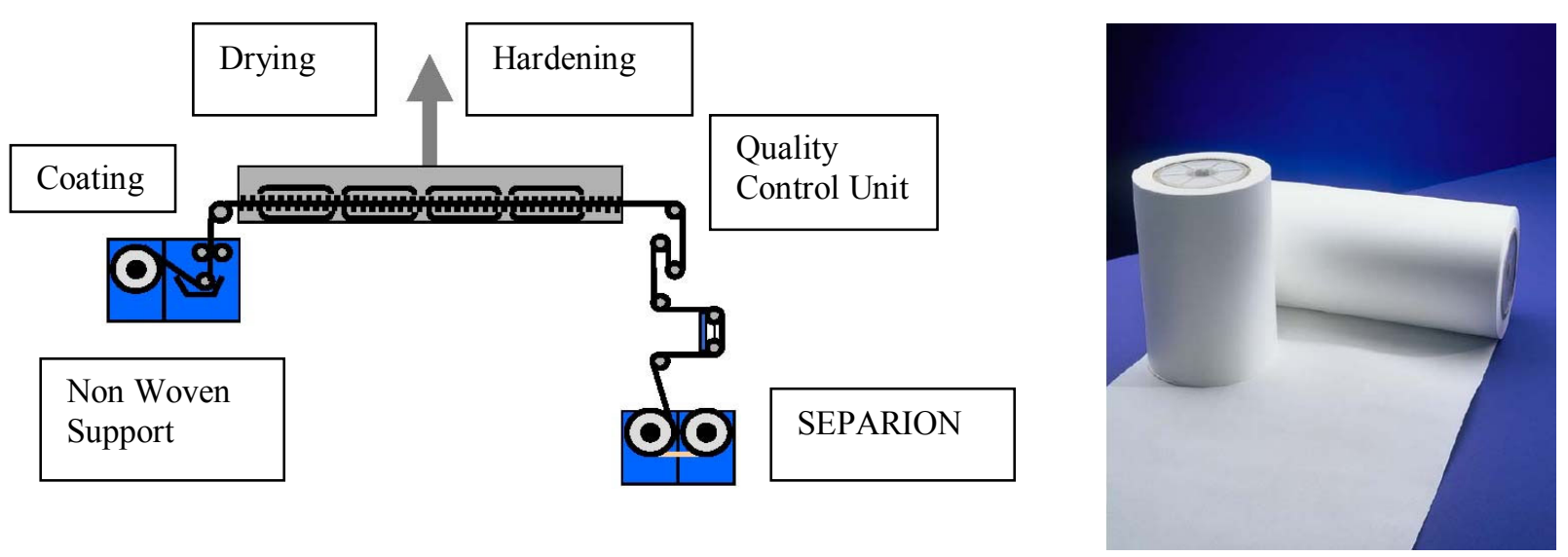

Fig. 57. Continuous Coating Process Used to Produce Degussa SEPARION Separator

\section{$\underline{\text { Electrochemical Performance Characteristics }}$}

Figure 58 is a HPPC pulse power ASI comparison of a cell that employs the Degussa SEPARION separator (Fig. 58a) with a cell that employs the Celgard separator (Fig. 58b). In both tests, we utilized a 10C current pulse and the cells employed our Gen 2 cell chemistry.

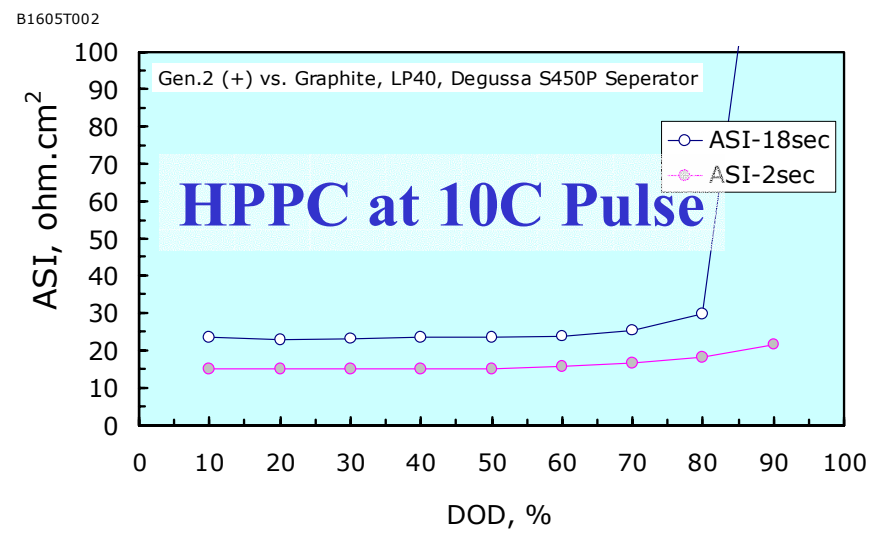

(a)

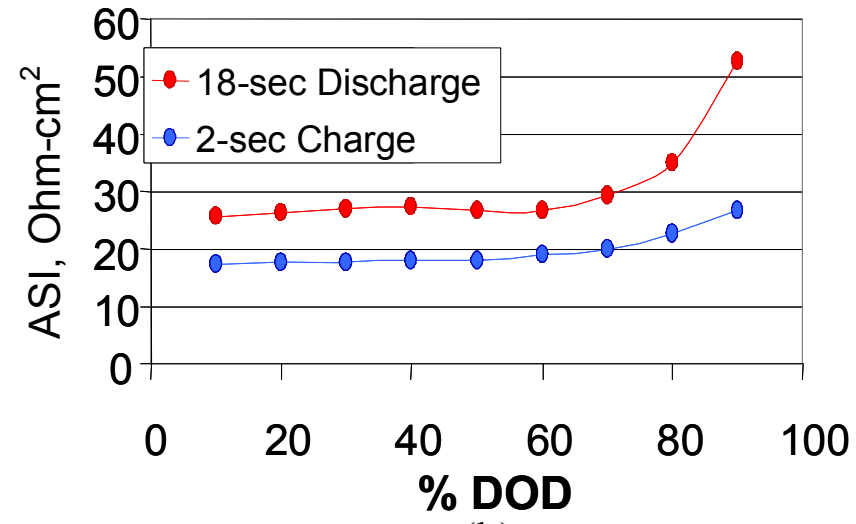

(b)

Fig. 58. HPPC Test Data for Cell Employing (a) SEPARION Separator and (b) Cell Employing Celgard Separator 


\title{
6. ADVANCED BINDERS
}

Binders are used as a component of Li-ion battery composite electrodes to bind the active materials to the current collector. In the cathode, electronic additives (typically carbon black and graphite powders) are included in the electrode mix. Maintaining intimate contact between these additives and the active materials is another role of the cathode binder.

Much of the international Li-ion battery industry has moved away from using PVDF binders in the anodes of their commercial cells, having replaced PVDF with soft butyl rubber (SBR) binders. The binders play a key role in preventing delamination of the composite electrode from the current collector. However, they can participate in the inherent safety characteristics of the cell, as well, via reactions with the electrode active materials and/or the electrolyte. Kureha, a long-time supplier of PVDF binders to the Li-ion battery industry, continues to improve upon its PVDF binders, in an effort to retain a portion of the market. ANL evaluated some of the newest PVDF binder materials from Kureha.

\subsection{PVDF BINDERS}

\subsubsection{Kureha}

\section{Contact Information}

\author{
A. Nagai \\ Kureha Chemical Industry Co., Ltd. \\ 1-9-11, Nihonbashi \\ Horidome-cho, chuo-ku \\ Tokyo 03-8552 Japan \\ Tel: $\quad 03-3249-4726$ \\ Fax: 03-3249-4603 \\ E-mail: a-nagai@kureha.co.jp
}

Kureha KF "L Series" binders are solutions of PVDF resins in a NMP solvent. The binding properties of the "L Series" binders are superior to those of the PVDF binders previously supplied by Kureha. L\#9300 is used as an ultrahigh adhesion-bonding binder for anodes in lithium-ion secondary batteries. When using this type of binder, high peel strengths are obtained even at low concentrations. This type of binder could have a positive impact on battery life and safety.

\section{Peel Strength Characteristics}

A typical anode mix contains about $8 \%$ (by weight) of binder, when using conventional binders, such as the Kureha KF\#9130 binder. A new Kureha binder (KF\#9300) offers significantly improved binding characteristics even at the 4\% (by weight) level (Fig. 59a). This presents an opportunity to lower costs, enhance component integrity, and/or increase the energy density of commercial cells. 
In a similar manner, Kureha has developed a new binder for the cathode. Its new KF\#2918 binder demonstrates exceptional binding properties even at the 4\% (by weight) level (Fig. 59b). Again, this presents an opportunity to lower costs, enhance component integrity, and/or increase the energy density of commercial cells.

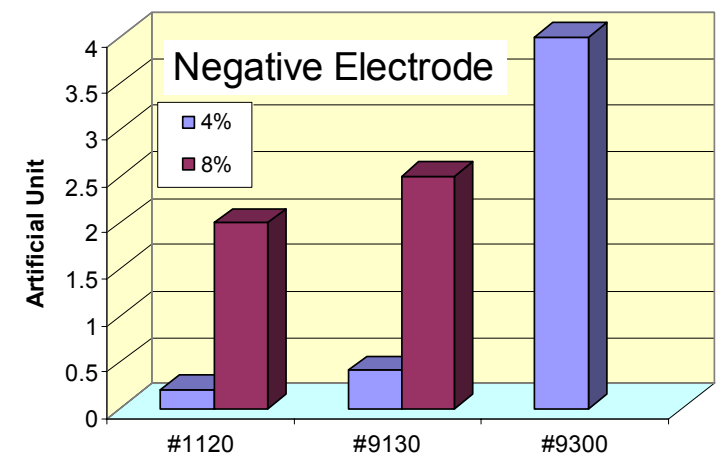

(a)

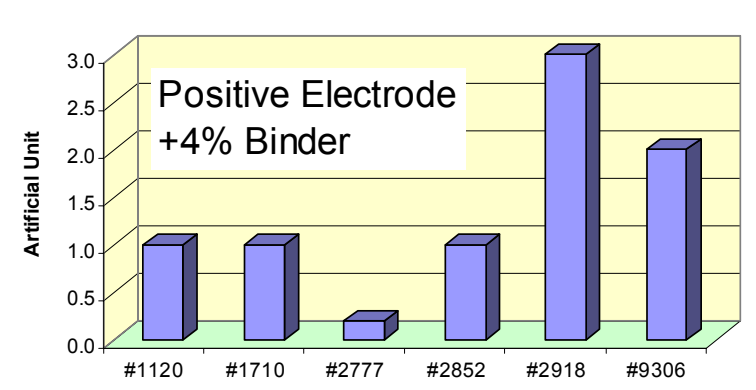

(b)

Fig. 59. Relative Peel Strengths of (a) Anodes and (b) Cathodes Made with Different Kureha Binders

\subsection{SBR BINDERS}

As mentioned above, SBR binders are an alternative to PVDF binders. All Japanese battery companies have switched to SBR binders for the negative electrode. However, use of these binders requires the development of new electrode processing technology.

ANL obtained the details of the processes developed for using both the Nippon Zeon and the JSR binders. These are the only two companies that mass produce the SBR binders. Information is available, if requested. Both companies will be shipping materials to ANL for evaluation in the near future. 


\section{STATUS SUMMARY}

ANL continues to obtain advanced materials from international material suppliers and continues working with them to optimize their materials for high-power applications. Based on the evaluations performed to date, it is possible to select materials for incorporation into advanced cell chemistries that would offer significant improvements in life, safety, and cost relative to our Gen 2 high-power cell chemistry.

In this section, we will discuss two of the most promising advanced cell chemistries. The electrode materials selected for these advanced cell chemistries are listed in Table 5, and the morphologies of these materials are shown in Figure 60. Also, alternative salts (e.g., LiBOB) and PC-based electrolyte systems are being studied and optimized as replacements for the $1.2 \mathrm{M}$ $\mathrm{LiPF}_{6}$-in-EC:EMC (3:7) electrolyte used in the Gen 2 cell chemistry.

Table 5. Electrode Materials Selected for Two of the Most Promising Advanced Cell Chemistries

\begin{tabular}{|l|l|l|l|}
\hline & Gen 2 Chemistry & Advanced Chemistry A & Advanced Chemistry B \\
\hline Cathode & $\mathrm{LiNi}_{0.8} \mathrm{Co}_{0.15} \mathrm{Al}_{0.05} \mathrm{O}_{2}$ & $\mathrm{LiNi}_{1 / 3} \mathrm{Co}_{1 / 3} \mathrm{Mn}_{1 / 3} \mathrm{O}_{2}$ & $\mathrm{LiMn}_{2} \mathrm{O}_{4}$ spinel \\
\hline Anode & $\mathrm{MAG}-10$ (synthetic) & GDR (natural graphite) & GDR (natural graphite) \\
\hline
\end{tabular}

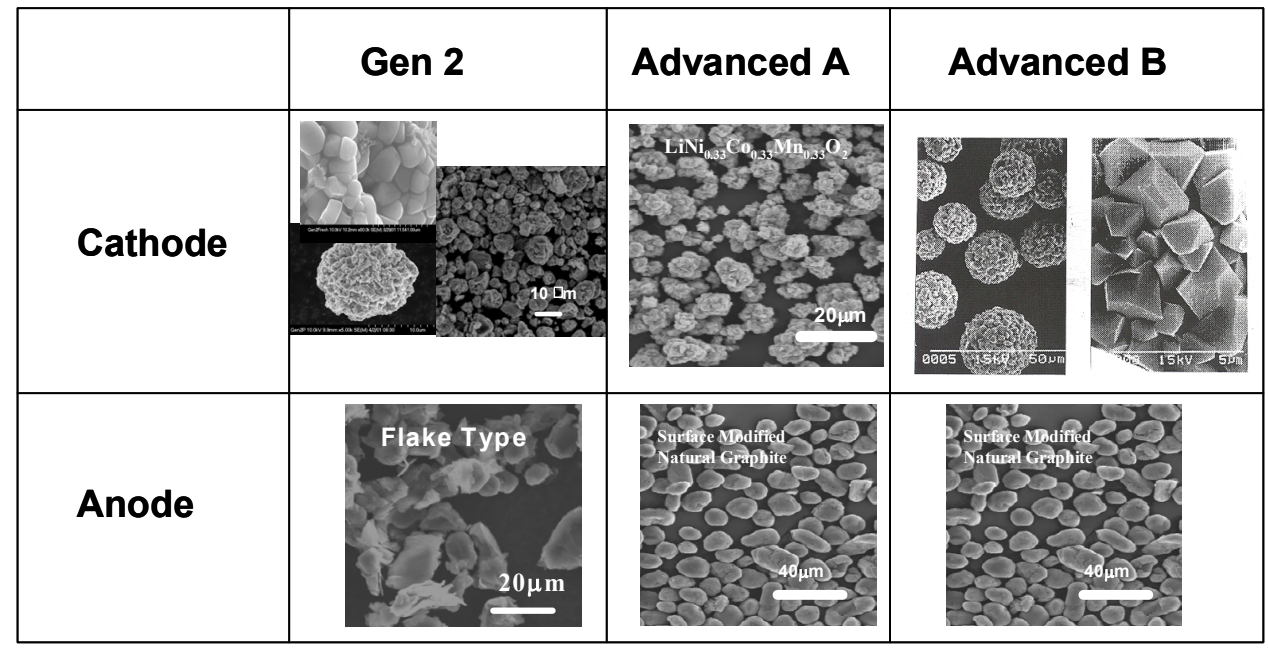

Fig. 60. SEM Images of Two of the Most Promising Advanced Cell Chemistries

The high-power performance of these two advanced cell chemistries compares favorably with our Gen 2 cell chemistry, as shown by the HPPC data provided in the Figure 61. 


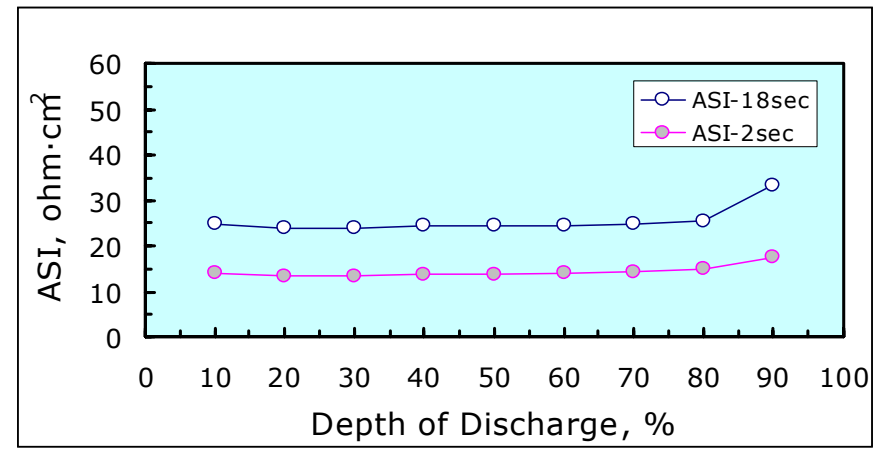

(a)

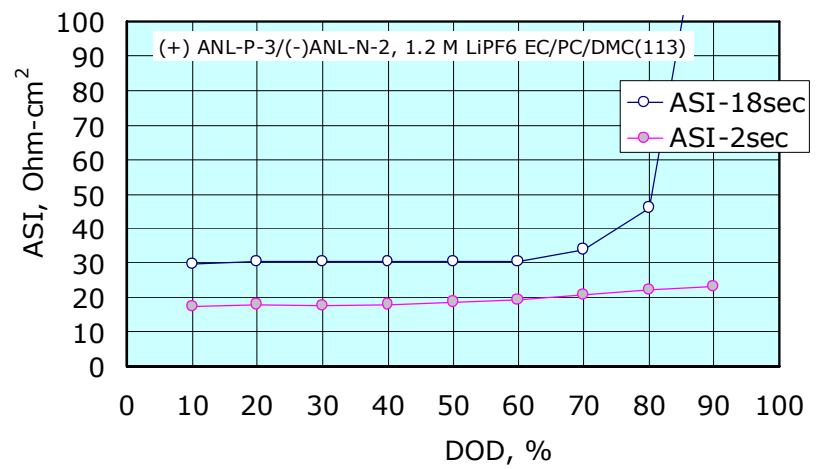

(b)

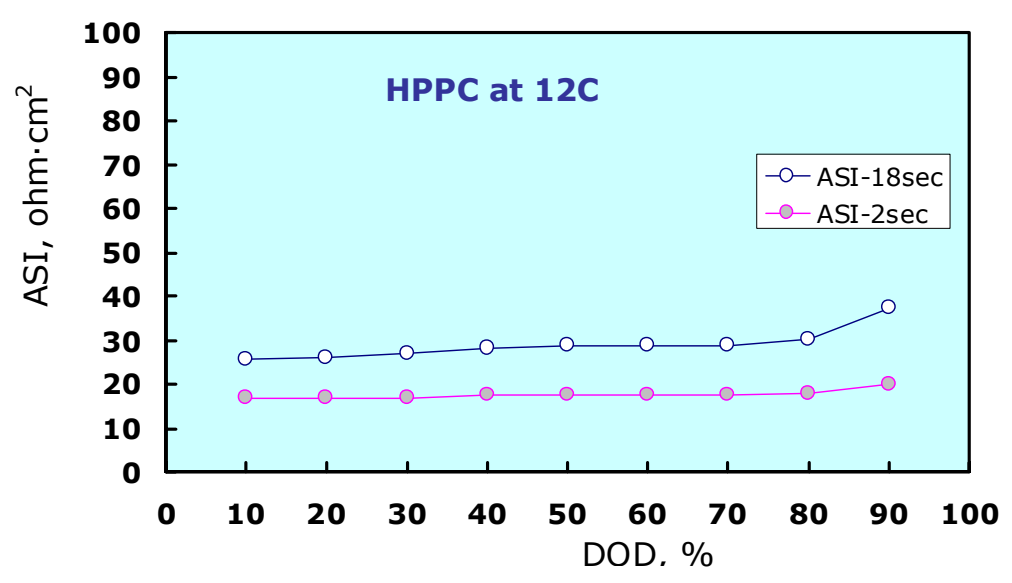

(c)

Fig. 61. HPPC Test Data for (a) Gen 2, (b) Advanced A, and (c) Advanced B Cell Chemistries

These advanced cell chemistries also appear to have significant inherent safety advantages over the Gen 2 cell chemistry. Figure 62 compares DSC safety characteristics of our Gen 1, Gen 2, and Advanced Chemistry A cathode materials at 100\% state of charge. All cells were charged to $4.3 \mathrm{~V}$ prior to harvesting the charged cathodes from the cells. In all cases, the electrolyte was 1.2 $\mathrm{M} \mathrm{LiPF}_{6}$ in EC:PC:DMC (1:1:3). The onset temperature for the first exothermic peak is shifted to a higher temperature ( $\sim 60$ degrees higher) when the $\mathrm{LiNi}_{1 / 3} \mathrm{Co}_{1 / 3} \mathrm{Mn}_{1 / 3} \mathrm{O}_{2}$ cathode material is used. From an inherent safety perspective, this is significant in terms of reducing the possibility of getting into a thermal runaway condition. Also, the total heat generation during the DSC run on the $\mathrm{LiNi}_{1 / 3} \mathrm{Co}_{1 / 3} \mathrm{Mn}_{1 / 3} \mathrm{O}_{2}$ cathode material is lower than the total heat generation during the DSC runs on the Gen 1 and Gen 2 cathode materials. 


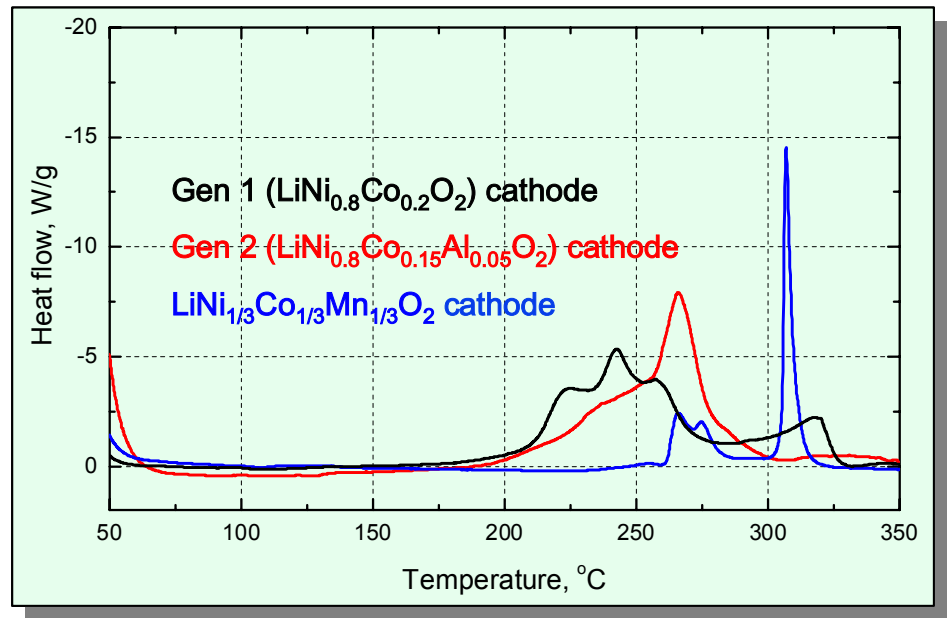

Fig. 62. Comparative DSC Data for Gen 1, Gen 2, and Advanced A Cathodes

The Al-doped stabilized spinel cathode used in Advanced Chemistry B possesses even better safety characteristics, as shown by DSC data on cathodes at 100\% SOC (Fig. 63). This is particularly true when a LiBOB electrolyte is employed.
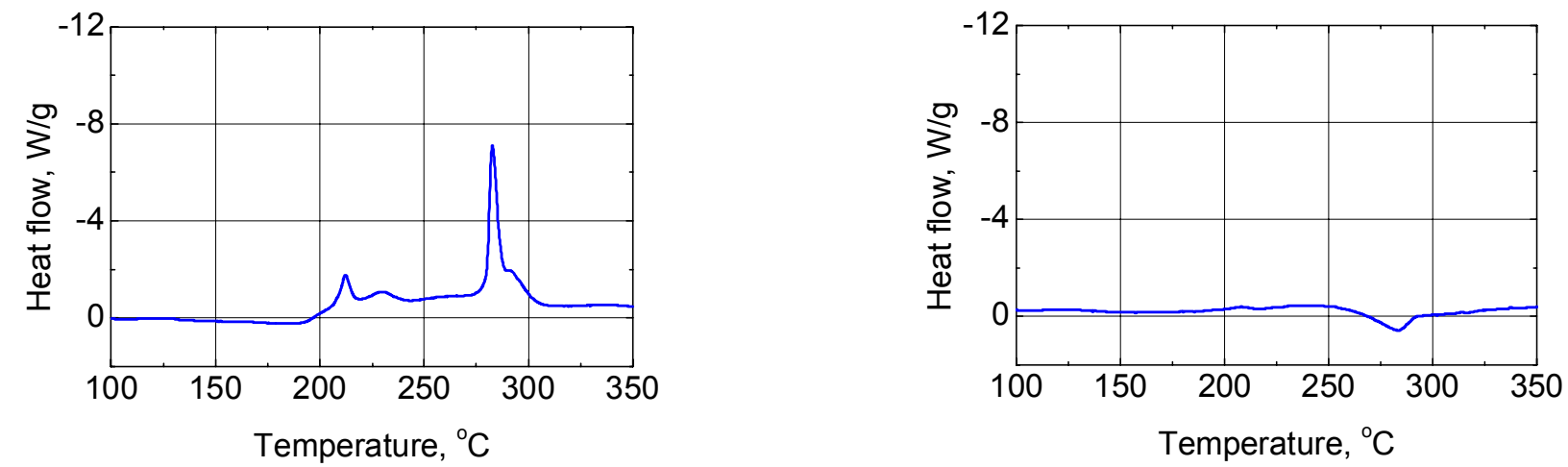

Fig. 63. DSC Data for Spinel Cathodes at 100\% SOC in (a) $1 \mathrm{M} \mathrm{LiPF}_{6}$ in EC:DEC (1:1) Electrolyte and (b) $1 \mathrm{M} \mathrm{LiBOB}$ in EC:DEC (1:1) Electrolyte

From an inherent safety perspective, the Gen 2 anode was known to be less than ideal, due to its flaky morphology. It was chosen for use in our Gen 2 cell chemistry primarily because it was significantly lower in cost than MCMB synthetic graphite $(\sim \$ 15 / \mathrm{kg}$ for the MAG-10 vs. $\$ 40-50 / \mathrm{kg}$ for the MCMB). Figure 64 shows comparative DSC data for our Gen 2 (MAG-10) anode and the GDR anode material selected for use in our advanced cell chemistries. Both anodes were highly lithiated when harvested from cells constructed with 1.2 M LiPF 6 EC:EMC (3:7) electrolyte. 


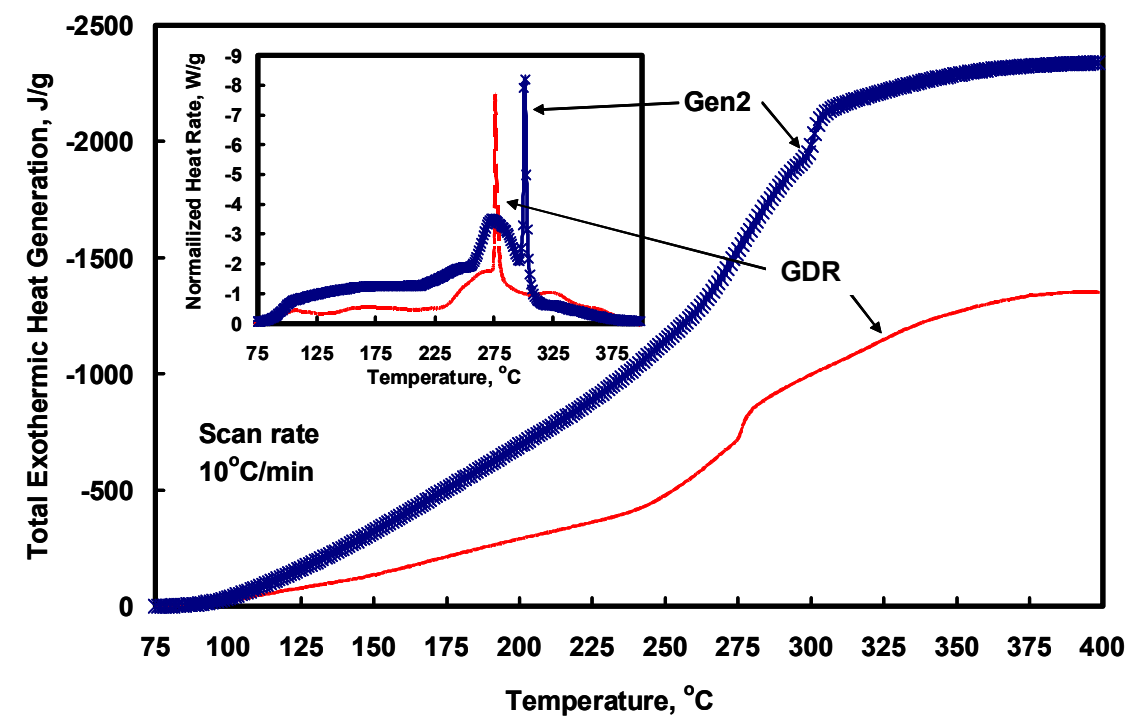

Fig. 64. Comparative DSC Data for Gen 2 (MAG-10) and GDR Graphite Anodes

Additional DSC safety data are provided in Figure 65. Here we compare the MCMB-6 (Gen 1) anode, MAG-10 (Gen 2) anode, and GDR (advanced chemistry) anode in the same electrolyte system. The quantity of heat generated by the GDR anode is only $58 \%$ of that generated by the MAG-10 anode.

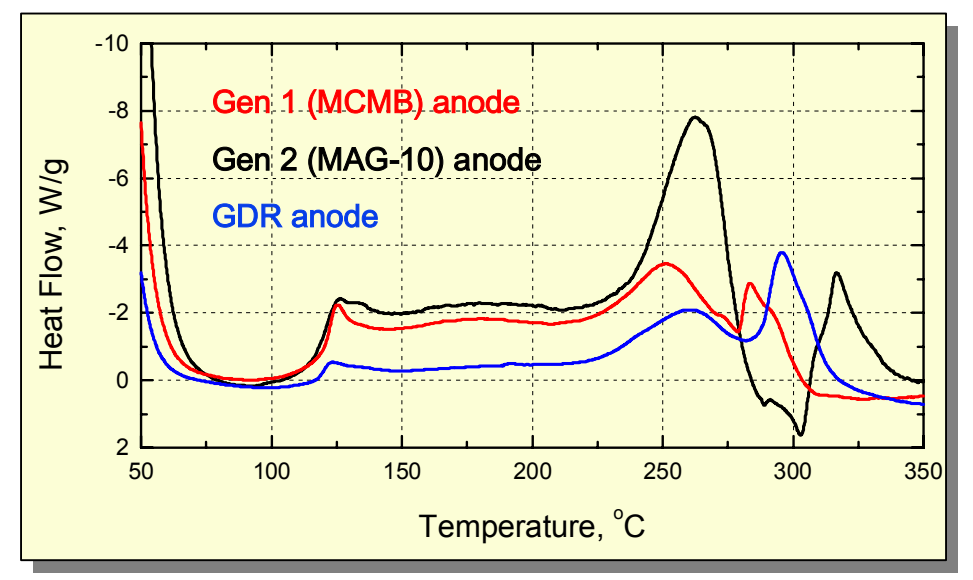

Fig. 65. DSC Data for Gen 1, Gen 2, and GDR Anode Materials in 1.2 $\mathrm{M} \mathrm{LiPF}_{6}$ in EC:PC:DMC $(1: 1: 3)$

One of the main reasons for selecting these materials for evaluation was their lower cost relative to the Gen 2 materials. Table 6 summarizes the cost information that was obtained on these materials from their suppliers. These costs are based on supplying sufficient quantities of these materials to build 100,000 HEV batteries/year as an introductory market. The material quantities were supplied by ANL, based on our battery designs for $25-\mathrm{kW}$ batteries which employ these cell chemistries. 
Table 6. Material Cost Projections for Gen 2, Advanced A, and Advanced B Cell Chemistries

\begin{tabular}{|c|c|c|c|}
\hline \multirow{2}{*}{ Cell Chemistry } & \multicolumn{3}{|c|}{ Material Cost Projection } \\
\cline { 2 - 4 } & Cathode (\$/kg) & Anode (\$/kg) & Electrolyte (\$/L) \\
\hline Gen 2 & 20.50 & 15.00 & 20.00 \\
\hline Advanced A & 13.00 & 10.00 & 16.00 \\
\hline Advanced B* & 7.40 & 10.00 & 16.00 \\
\hline
\end{tabular}

*Additional cost advantages are inherent in the Advanced $\mathrm{B}$ cell chemistry, due to the higher power capability of the spinel cathode. This means one can design the battery with smaller capacity cells, thereby reducing the quantities of all materials used in the cells.

Figure 66 illustrates the potential battery-level material cost reductions that could be achieved with these two advanced cell chemistries, relative to our Gen 2 cell chemistry, in a 25$\mathrm{kW}$ HEV battery. Use of the $\mathrm{LiMn}_{2} \mathrm{O}_{4}$ spinel cathode allows a significant reduction in the cell capacity, because of its very high rate capability. This is a major factor in reducing the cell material costs to $<\$ 10 / \mathrm{kW}$.

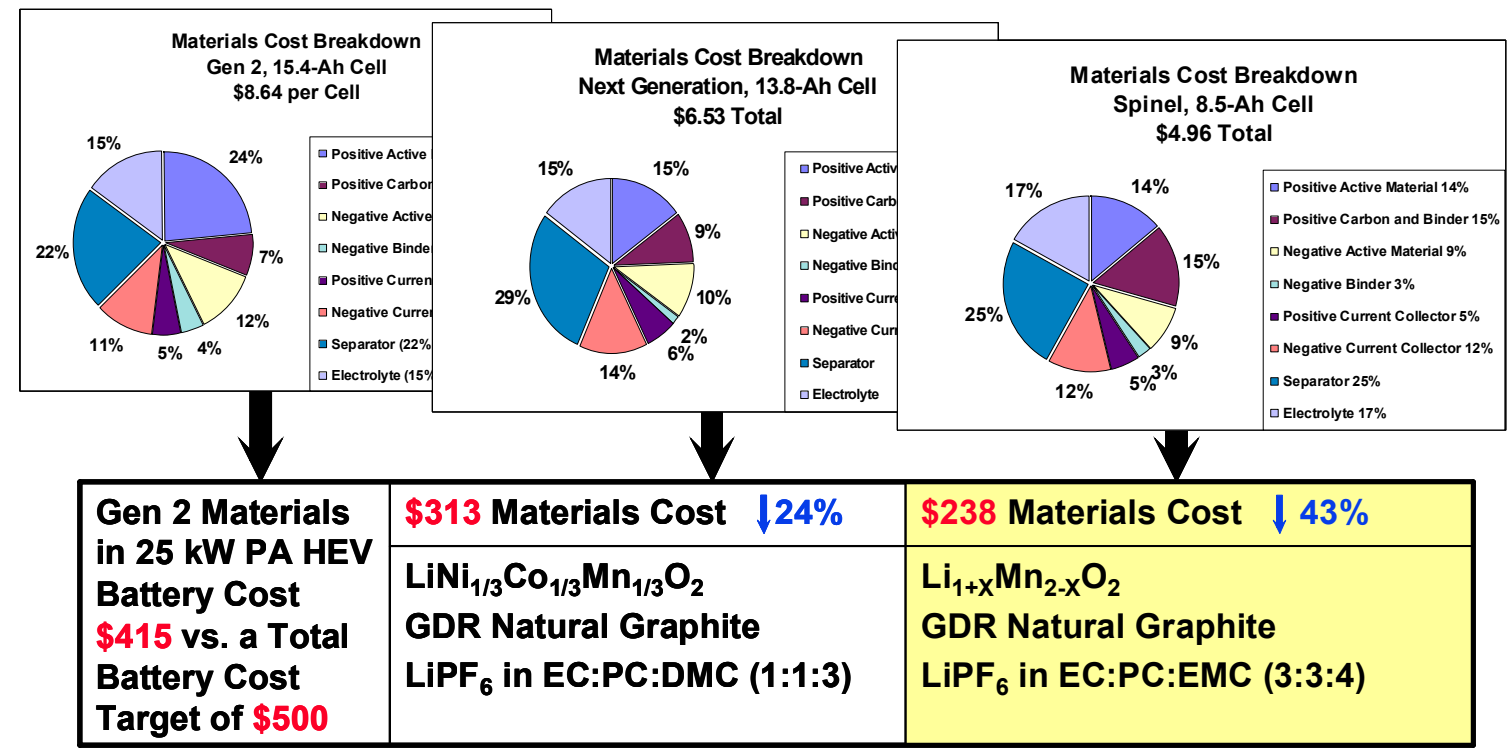

Fig. 66. Projected Battery-Level Material Costs for the Gen 2, Advanced A, and Advanced B Cell Chemistries 


\section{CONCLUSIONS}

The conclusions from the work documented in this report can be summarized as follows:

- $\mathrm{LiNi}_{1 / 3} \mathrm{Co}_{1 / 3} \mathrm{Mn}_{1 / 3} \mathrm{O}_{2}$ and $\mathrm{LiMn}_{2} \mathrm{O}_{4}$ spinel cathodes possess equivalent or better high-rate performance and are less reactive thermally than $\mathrm{LiNi}_{0.8} \mathrm{Co}_{0.15} \mathrm{Al}_{0.05} \mathrm{O}_{2}$.

- The carbon-coated and round-edge GDR natural graphite possesses good high-rate capabilities and is much less thermally reactive than the flaky MAG-10 synthetic graphite (and even appears to be less thermally reactive than MCMB).

- Additional thermal stability enhancements appear achievable via the use of:

- LiBOB salt.

- PC-based electrolytes.

- VEC electrolyte additive.

- All material costs are considerably lower than Gen 2 materials.

Some additional preliminary conclusions were reached. The Degussa SEPARION separators appear to have performance characteristics similar to conventional separators and to offer some potential for cost reductions. The Kureha KF "L Series" binders appear to offer advantages over previous PVDF binders in that they exhibit very high peel strengths when used at only the $4 \%$ (by weight) level in an electrode mix. This should translate to some cost savings and higher energy densities.

In the future, ANL will continue identifying, securing, and evaluating advanced materials from international material suppliers. Most of these materials are being developed for use in high-energy commercial cells. Therefore, ANL will continue to provide feedback to the material suppliers and recommend changes that will render their advanced materials more optimal for the high-power HEV, 42-volt, and FCEV applications. We are working to obtain samples of the new low-cost separator materials that are being developed under the FreedomCAR-sponsored R\&D projects, and these materials will be evaluated. Future reports of this type will be published and distributed to keep the industrial developers of high-power lithium-ion batteries informed on our progress. 


\section{REFERENCES}

1. Henriksen, G.L., K. Amine, J. Liu, and P.A. Nelson, Materials Cost Evaluation Report for High-Power Li-Ion HEV Batteries, ANL-03/5, Argonne National Laboratory, Argonne, Illinois, December 2002. 


\section{APPENDIX A: INDEX OF MATERIALS}

\begin{tabular}{|c|c|c|c|}
\hline$\underline{\text { Sample }}$ & Company & Material & $\underline{\text { Page }}$ \\
\hline GDR & Mitsui & Anode & 9 \\
\hline DJG New 3 & Daibeck & Anode & 13 \\
\hline SLC 10U & Pred Materials & Anode & 15 \\
\hline SLC 1015 & Superior Graphite & Anode & 17 \\
\hline FU 2651 & Schunk & Anode & 18 \\
\hline TIMREX E-SLP 50 & TIMCAL & Anode & 20 \\
\hline C-C Composite & LiTech & Anode & 20 \\
\hline L333 & Seimi & Cathode & 24 \\
\hline $\mathrm{LiNi}_{1-\mathrm{x}} \mathrm{Ti}_{\mathrm{x}} \mathrm{O}_{2}$ & Fuji & Cathode & 28 \\
\hline Spinel & Tosoh & Cathode & 30 \\
\hline Spinel & Japan Metals & Cathode & 35 \\
\hline M-216 spinel & Seimi & Cathode & 36 \\
\hline SEPARION & Degussa & Separator & 37 \\
\hline KF\#9300 & Kureha & Binder (negative) & 39 \\
\hline $\mathrm{KF} \# 2918$ & Kureha & Binder (positive) & 40 \\
\hline
\end{tabular}




\section{APPENDIX B: MATERIALS DATA SUMMARY}

The following is a list of physical and chemical data currently available for materials in this report. It is arranged in the order of text discussion.

GDR-AA-2 (Mitsui Mining)

Physical analysis

Surface area $\left(\mathrm{m}^{2} / \mathrm{g}\right) \quad 1.7$

Tap density $(\mathrm{g} / \mathrm{mL}) \quad 0.93$

Particle size distribution by laser diffraction

D-10 $(\mu \mathrm{m}) \quad 14.5$

D-50 $(\mu \mathrm{m}) \quad 26.6$

D-90 $(\mu \mathrm{m}) \quad 38.6$

DJG New 3 (Daibeck) Amorphous carbon coated natural graphite

Physical analysis

Surface area $\left(\mathrm{m}^{2} / \mathrm{g}\right) \quad 2.8-3.2$

Tap density $(\mathrm{g} / \mathrm{mL}) \quad 0.981-0.985$

Bulk denisity $(\mathrm{g} / \mathrm{mL}) \quad 0.54$

Particle size distribution by laser diffraction

D-10 $(\mu \mathrm{m}) \quad 9.8-10.5$

D-50 $(\mu \mathrm{m}) \quad 20.3-20.8$

D-90 $(\mu \mathrm{m}) \quad 39.3-39.8$

$\underline{\text { SLC 10U Chinese graphite }}$

Physical analysis

Surface area $\left(\mathrm{m}^{2} / \mathrm{g}\right) \quad \mathrm{NA}$

Tap density $(\mathrm{g} / \mathrm{mL}) \quad \mathrm{NA}$

Particle size distribution by laser diffraction

D-10 $(\mu \mathrm{m}) \quad$ NA

D-50 $(\mu \mathrm{m}) \quad 11.66$

D-90 $(\mu \mathrm{m}) \quad$ NA

$\underline{\text { SLC } 1015 \text { (Superior Graphite) }}$

Physical analysis

Surface area $\left(\mathrm{m}^{2} / \mathrm{g}\right) \quad 1.42$

Tap density $(\mathrm{g} / \mathrm{mL}) \quad 0.8$ 
Particle size distribution by laser diffraction

D-10 $(\mu \mathrm{m}) \quad 8.6$

D-50 $(\mu \mathrm{m}) \quad 14$

D-90 $(\mu \mathrm{m}) \quad 25$

FU 2651 (Schunk)

Physical analysis

Surface area $\left(\mathrm{m}^{2} / \mathrm{g}\right) \quad 2$

Tap density $(\mathrm{g} / \mathrm{mL}) \quad 2.24$

Particle size distribution by laser diffraction $\mathrm{D}-10(\mu \mathrm{m}) \quad 5$

D-50 $(\mu \mathrm{m}) \quad 13$

D-90 $(\mu \mathrm{m}) \quad 38$

\section{TIMREX E-SLP 50 (TIMCAL)}

Physical analysis

Surface area $\left(\mathrm{m}^{2} / \mathrm{g}\right) \quad$ NA

Tap density $(\mathrm{g} / \mathrm{mL}) \quad 2.6$

Particle size distribution by laser diffraction

D-10 $(\mu \mathrm{m}) \quad$ NA

D-50 $(\mu \mathrm{m}) \quad \mathrm{NA}$

D-90 $(\mu \mathrm{m}) \quad$ NA

$\underline{\mathrm{L}-333, \mathrm{LiNi}_{1 / 3}} \underline{\mathrm{Mn}_{1 / 3}} \underline{\mathrm{Co}_{1 / 3}} \underline{\mathrm{O}}_{2} \underline{\text { (Seimi) }}$

Physical analysis

Surface area $\left(\mathrm{m}^{2} / \mathrm{g}\right) \quad 0.6$

Tap density $(\mathrm{g} / \mathrm{mL}) \quad 2.2$

Press density $(\mathrm{g} / \mathrm{mL}) \quad 2.6$

Particle size distribution by laser diffraction

$\mathrm{D}-10(\mu \mathrm{m}) \quad 6.92$

D-50 $(\mu \mathrm{m}) \quad 10.74$

D-90 $(\mu \mathrm{m}) \quad 15.56$

$\underline{\mathrm{LiNi}_{0.95}} \underline{\mathrm{Ti}_{0.05}} \underline{\mathrm{O}_{2}}$ (Fuji)

Physical analysis

Surface area $\left(\mathrm{m}^{2} / \mathrm{g}\right) \quad$ NA

Tap density $(\mathrm{g} / \mathrm{mL}) \quad$ NA 
Particle size distribution by laser diffraction

D-10 $(\mu \mathrm{m}) \quad$ NA

D-50 $(\mu \mathrm{m}) \quad$ NA

D-90 $(\mu \mathrm{m}) \quad$ NA

$\underline{\mathrm{LiNi}_{0.92}} \underline{\mathrm{Ti}_{0.05}} \underline{\mathrm{Al}_{0.03}} \underline{\mathrm{O}_{2}}($ Fuji)

Physical analysis

Surface area $\left(\mathrm{m}^{2} / \mathrm{g}\right) \quad 0.16$

Tap density (g/mL) 2.48 (tapped 1000 times)

Particle size distribution by laser diffraction

D-10 $(\mu \mathrm{m}) \quad 6.9$

D-50 $(\mu \mathrm{m}) \quad 11.2$

D-90 $(\mu \mathrm{m}) \quad 19.9$

\section{Al-doped spinel (Tosoh)}

Physical analysis

Surface area $\left(\mathrm{m}^{2} / \mathrm{g}\right) \quad 0.56$

Tap density $(\mathrm{g} / \mathrm{mL}) \quad 1.82$

Particle size distribution by laser diffraction

D-10 $(\mu \mathrm{m}) \quad 7.42$

D-50 $(\mu \mathrm{m}) \quad 17.78$

D-90 $(\mu \mathrm{m}) \quad 30.08$

$\underline{\mathrm{Li}_{1.06}} \underline{\mathrm{Mn}_{1.94}} \underline{\mathrm{O}}_{4}$ spinel (Tosoh)

Physical analysis

Surface area $\left(\mathrm{m}^{2} / \mathrm{g}\right) \quad 0.53$

Tap density $(\mathrm{g} / \mathrm{mL}) \quad 1.82$

Bulk density $(\mathrm{g} / \mathrm{mL}) \quad 1.10$

$\mathrm{Li} / \mathrm{Mn}=\quad 0.586$

Particle size distribution by laser diffraction

D-10 $(\mu \mathrm{m}) \quad 8.36$

D-50 $(\mu \mathrm{m}) \quad 16.85$

D-90 $(\mu \mathrm{m}) \quad 26.68$

\section{LM-123 spinel (JMC)}

Physical analysis

Surface area $\left(\mathrm{m}^{2} / \mathrm{g}\right) \quad 1.13$

Tap density $(\mathrm{g} / \mathrm{mL}) \quad 1.98$ 
Particle size distribution by laser diffraction

D-10 $(\mu \mathrm{m}) \quad 3.3$

D-50 $(\mu \mathrm{m}) \quad 10.7$

D-90 $(\mu \mathrm{m}) \quad 20.5$

M-216 Al-doped spinel (Seimi)

Physical analysis

Surface area $\left(\mathrm{m}^{2} / \mathrm{g}\right) \quad 1.2$

Tap density $(\mathrm{g} / \mathrm{mL}) \quad 2.2$

Press density $(\mathrm{g} / \mathrm{mL}) \quad 2.6$

Particle size distribution by laser diffraction

D-10 $(\mu \mathrm{m}) \quad 5.1$

D-50 $(\mu \mathrm{m}) \quad 16.3$

D-90 $(\mu \mathrm{m}) \quad 36.3$ 


\section{APPENDIX C: COMPANY CONTACT INFORMATION}

Following is an alphabetical list of companies with associated contact information:

Company Information

Chemetall $\mathrm{GmbH}$

Trakehner Strasse 3

D-60487 Frankfurt am Main

Germany

Tel: $\quad$ (0 69) $7165-3076$

Fax: $\quad(069) 7165-3622$

E-mail: Ulrich.wietelmann@chemetall.com

Internet: www.chemetall.com
Contact

Ulrich Wietelmann

Daibeck Advanced Materials Co., Ltd.

Leeki Lee

990-3, Madu-Dong, Ilsan-Gu

Goyang City

Kyunggi-Do, Korea

Tel: $\quad$ (82-31) 900-1616

Fax: $\quad$ (82-2) 2645-1873

E-mail: leeki@daibeck.co.kr

Internet: www.daibeck.co.kr

Degussa

Paul-Baumann-Strasse 1

V. Hennige

Gebaude 1266/14

45764 Marl

Germany

Tel: $\quad+49-2365-49-4267$

Fax: $\quad+49-23$ 65-49-80 4267

E-mail: Volker.hennige@degussa.com

Internet: www.creavis.de

Fuji Chemical Industry Co., Ltd.

1-26, Hibiki-cho, Wakamatsu-ku, Kitakyusyu-shi

Masami Ueda

Fukuoka 808-0021, Japan 
Tel: $\quad 81-93-771-7799$

Fax: 81-93-771-8090

E-mail: ueda@fujichemical.co.jp

Japan Metals \& Chemicals Co., Ltd.

Eiichi Shimizu

Advanced Materials Dept.

JMC Building

No. 8-4, Koami-cho, Nihonbashi

Chuo-ku, Tokyo 103-8531 Japan

Tel: $\quad 81-3-3667-2502$

Fax: 81-3-3667-3193

E-mail: shimzue@jmc.co.jp

Kureha Chemical Industry Co., Ltd.

1-9-11, Nihonbashi

Aisahu Nagai

Horidome-cho, chuo-ku

Tokyo 03-8552 Japan

Tel: $\quad 03-3249-4726$

Fax: 03-3249-4603

E-mail: a-nagai@kureha.co.jp

Mitsui Mining Material Co., Ltd.

3-3, Toyosu 3-chome, Koto-Ku

Tokyo, 135-6006 Japan

Tel: $\quad 81-3-5560-2114$

Fax: 81-3-5560-2192

Pred Materials International

The Lincoln Building

Stephen Pred

60 East $42^{\text {nd }}$ St. Suite 1456

New York, NY 10165

Tel: $\quad 212-286-0068$

Fax: 212-286-0072

Schunk Graphite Technology

Michaela Baker

W146 N9300 Held Drive

Menomonee Falls, WI 53051-1643 
Tel: $\quad 262-250-8869$

Fax: 262-255-1391

E-mail: Michaela@schunkgraphite.com

Seimi Chemical Co., Ltd.

Manabu Suhara

3-2-10, Chigasaki

Chicasaki-City

Kanagawa, 253-8585

Japan

Tel: $\quad+81-467-82-4131$

Fax: $\quad+81-467-88-1778$

E-mail: mnbsuhara@seimichemical.co.jp

Internet: www.seimichemical.co.jp

Superior Graphite

Igor Barsukov

10 South Riverside Plaza

Chicago, IL 60606

Tel: $\quad 312-559-2999$

Fax: $\quad 800-892-7795$

Internet: www.graphitesgc.com

Timical Ltd. Graphites and Technology

CH-5643

Sins, Switzerland

Tel: $\quad 41-91-8732010$

Fax: 41-91-873 2009

E-mail: m.spahr@ch.timical.com

Tosoh Corporation

Masaki Okada

Nanyo Research Laboratory

4560, Kaisei-cho, Shin-nanyo, 746-8501 Japan

Tel: $\quad 81-834-63-9937$

Fax: 81-834-63-9923

E-mail: okada_m@tosoh.co.jp 
Distribution for ANL-03/16

Internal (Printed Copy Only):
K. Amine
A. Kahaian
J. F. Miller
I. Belharouak
S. Kang
S. K. Zussman
G. L. Henriksen (50)
J. Liu

Internal (Electronic Copy Only):

M. R. Hale, TIS

D. Lewis

\section{External (Printed Copy Only):}

C. Ashtiani, DaimlerChrysler, Rochester Hills, MI 48309

J. Barnes, USDOE, Washington, DC

V. Battaglia, Argonne National Laboratory, Washington, DC

O. Bitsche, DaimlerChrysler, Stuttgart, Germany

D. Doughty, Sandia National Laboratories, Albuquerque, NM

T. Duong, USDOE, Washington, DC

M. A. Habib, General Motors Corp., Warren, MI

E. Heim, San Rafael, CA

T. R. Jow, Army Research Laboratory, Adelphi, MD

R. Lagerstrom, DaimlerChrysler, Rochester Hills, MI

R. Matejek, DaimlerChrysler, Rochester Hills, MI

J. McBreen, Brookhaven National Laboratory, Upton, NY

F. R. McLarnon, Lawrence Berkeley National Laboratory, Berkeley, CA

T. Miller, Ford Motor Co., Dearborn, MI

C. Motloch, INEEL, Idaho Falls, ID

T. Murphy, INEEL, Idaho Falls, ID

K. Nechev, SAFT America, Inc., Cockeysville, MD

N. Pinsky, Southern California Edison, Rosemead, CA

W. Schank, Ford Motor Co., Dearborn, MI

L. Simmering, Ford Motor Co., Dearborn, MI

H. Tataria, General Motors Corp., Troy, MI

B. Thomas, DaimlerChrysler, Auburn Hills, MI

M. Verbrugge, General Motors Corp., Troy, MI

External (Electronic Copy Only):

M. A. Buckley, ANL Library-E

E. Sackett, ANL Library-W

Chemical Technology Division Review Committee Members:

H. U. Anderson, University of Missouri-Rolla, Rolla, MO

R. A. Greenkorn, Purdue University, West Lafayette, IN 
C. L. Hussey, University of Mississippi, University, MS M. V. Koch, University of Washington, Seattle, WA

V. P. Roan, Jr., University of Florida, Gainesville, FL

J. R. Selman, Illinois Institute of Technology, Chicago, IL

J. S. Tulenko, University of Florida, Gainesville, FL 